\title{
AVALIAÇÃO DO DESEMPENHO ESTRUTURAL DE SISTEMAS CONSTRUTIVOS INOVADORES: ESTUDO DE CASO
}

FABIANA LOPES DE OLIVEIRA

Dissertação apresentada à Escola de Engenharia de São Carlos, da Universidade de São Paulo, como parte dos requisitos para obtenção do Título de Mestre em Engenharia de Estruturas.

ORIENTADOR: Prof. Dr. Eloy Ferraz Machado Junior

São Carlos

1996 
Ciasa

Curt.

4007

Tombo 1019197

st 0746627

Oliveira, Fabiana Lopes de

047a Avaliação do desempenho estrutural de sistemas construtivos inovadores: estudo de caso / Fabiana Lopes de Oliveira. -- São Carlos, 1996.

$108 \mathrm{p}$.

Dissertação (Mestrado) -- Escola de Engenharia de São CarlosUniversidade de São Paulo, 1996.

Orientador: Prof.Dr. Eloy Ferraz Machado Júnior

1. Sistemas construtivos inovadores. 2. Avaliação de desempenho. I. Título. 
Ao meu amado marido, Edgard Sousa Junior, principal e fiel companheiro nesta gratificante jornada. 


\section{AGRADECIMENTOS}

A Deus pela fé e perseverança que proporcionaram a conclusão deste trabalho. "Ainda que eu andasse pelo vale da sombra da morte, não temeria mal algum, porque Tu estás comigo" (SL23;4).

Ao prof. Dr. Eloy Ferraz Machado Junior pela valiosa orientação, durante todo o período de estudo.

A meus pais, base de toda minha educação, pelo apoio e incentivo que sempre me deram.

A meus sogros pela ajuda e estímulo durante todo o curso de pósgraduação.

À CAPES pela ajuda financeira.

À COHAB-RP que possibilitou o desenvolvimento das atividades experimentais.

A Flávio A. O. Frias e Rodrigo D. C. Gonçalves pela ajuda mútua no desenvolvimento dos nossos trabalhos.

Aos funcionários do Laboratório da EESC (Amaury, Jorge, Mário, Mauri, e Valdir) e do CETEC (Centro Tecnológico de Lins) pelo trabalho desenvolvido em campo.

A todos os colegas, professores e funcionários do Departamento de Engenharia de Estruturas da Escola de Engenharia de São Carlos, em especial a Maria Nadir Minatel e Rosi Aparecida Jordão Rodrigues, pela ajuda e amizade durante o período de convivência. 


\section{SUMÁRIO}

LISTA DE FIGURAS ….......................................................... i

LISTA DE TABELAS …............................................................ iv

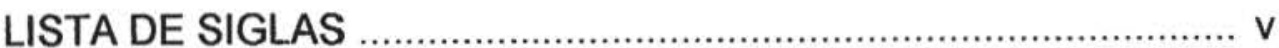

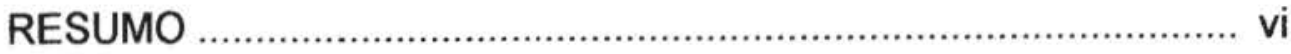

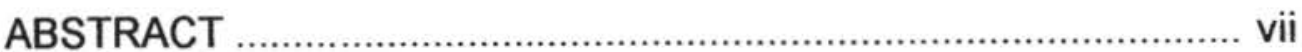

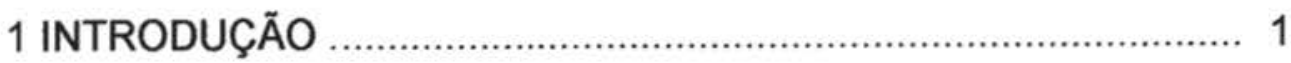

2 HISTÓRICO

3 METODOLOGIA DA AVALIAÇÃO DE DESEMPENHO ………......13

3.1 Requisitos e critérios de desempenho .................................. 17

3.2 Métodos de avaliação ......................................................... 18

4 AVALIAÇÃO DE DESEMPENHO ESTRUTURAL ....................... 20

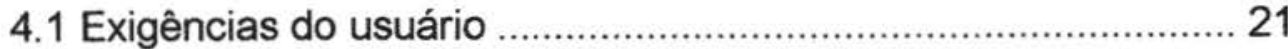

4.2 Condições de exposição ..................................................... 22

4.3 Requisitos de desempenho estrutural ................................... 23

4.3.1 Requisitos de desempenho estrutural para ação de impactos de corpo mole .....................................................23

4.3.2 Requisitos de desempenho estrutural para ação de impactos de corpo duro ................................................. 24

4.3.3 Requisitos de desempenho estrutural para ação de cargas provenientes de peças suspensas 
4.3.4 Requisitos de desempenho estrutural para solicitações transmitidas por fechamento brusco de portas

4.4 Critérios de desempenho estrutural

4.4.1 Critérios de desempenho estrutural para ação de impactos de corpo mole

4.4.2 Critérios de desempenho estrutural para ação de impactos de corpo duro

4.4.3 Critérios de desempenho estrutural para ação de cargas provenientes de peças suspensas

4.4.4 Critérios de desempenho estrutural para solicitações transmitidas por fechamento brusco de portas

4.5 Métodos de avaliação estrutural 26

4.5.1 Ensaio para verificação do comportamento sob ação de impactos de corpo mole de grande dimensão

4.5.2 Ensaio para verificação do comportamento sob ação de impactos de corpo duro de pequena e grande dimensão

4.5.3 Ensaio para verificação do comportamento sob ação de cargas provenientes de peças suspensas

4.5.4 Ensaio para verificação do comportamento sob ação de fechamentos bruscos de portas

5 ESTUDO DE CASO 34

5.1 Avaliação de desempenho: metodologia aplicada ..................... 35

5.2 Análise dos resultados

5.2.1 Ensaio de verificação do comportamento sob ação de impactos de corpo mole de grande dimensão

5.2.2 Ensaio de verificação do comportamento sob ação de impactos de corpo duro de pequena e grande dimensão

5.2.3 Ensaio de verificação do comportamento sob ação de cargas provenientes de peças suspensas 
5.2.4 Ensaio de verificação do comportamento sob ação de fechamentos bruscos de portas

5.3 Avaliação dos sistemas construtivos 73

5.3.1 Ensaio de verificação do comportamento sob ação de impactos de corpo mole de grande dimensão

5.3.2 Ensaio de verificação do comportamento sob ação de impactos de corpo duro de pequena e grande dimensão

5.3.3 Ensaio de verificação do comportamento sob ação de cargas provenientes de peças suspensas 79

5.3.4 Ensaio de verificação do comportamento sob ação de fechamentos bruscos de portas 82

5.4 Dificuldades encontradas e sugestões 85

6 CONCLUSÕES .87

ANEXOS 92

BIBLIOGRAFIA 104 


\section{LISTA DE FIGURAS}

FIGURA 01-Interação entre linhas de atuação .................................... 12

FIGURA 02-Proposta de interação entre linhas ...................................... 12

FIGURA 03-Esquema dos processos construtivos ............................. 13

FIGURA 04-Rota de transformação ou caminho de evolução .................. 14

FIGURA 05-Processo de avaliação de desempenho ............................. 16

FIGURA 06-Representação do ensaio de impactos de corpo mole de

grande dimensão .......................................................26

FIGURA 07-Esquema do ensaio de impacto de corpo mole de grande

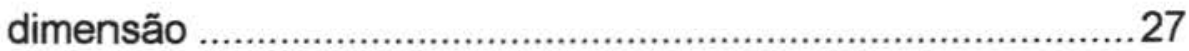

FIGURA 08-Representação do ensaio de impactos de corpo duro ......... 28

FIGURA 09-Esquema do ensaio de impacto de corpo duro .................... 29

FIGURA 10-Representação do ensaio de cargas provenientes de

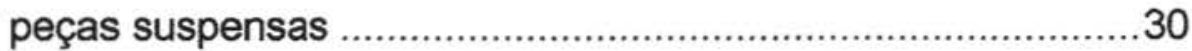

FIGURA 11-Esquema do ensaio de cargas provenientes de peças suspensas

FIGURA 12-Representação do ensaio de fechamento brusco de portas 32

FIGURA 13-Esquema do ensaio de fechamento brusco de portas 33

FIGURA 14-Sistema construtivo convencional - padrão COHAB.

Vista do ensaio 49

FIGURA 15-Sistema construtivo convencional - padrão COHAB.

Aspecto externo da parede ensaiada após o impacto de 960J

FIGURA 16-Sistema construtivo D. Vista interna da parede ensaiada 50

FIGURA 17-Sistema construtivo I. Preparativos para o ensaio 50

FIGURA 18-Sistema construtivo H. Configuração do estado de ruína da parede. Lado externo. Impacto com energia de 960J 
FIGURA 19-Sistema construtivo K. Estado final do sistema para medição das deformações horizontais após impacto de $720 \mathrm{~J}$

FIGURA 20-Sistema construtivo K. Configuração do estado de ruína do painel. Vista externa após impacto de $720 \mathrm{~J}$

FIGURA 21-Sistema construtivo I. Vista do ensaio com esfera de $0,5 \mathrm{~kg}$ 56

FIGURA 22-Sistema construtivo D. Vista do ensaio com esfera de $1,0 \mathrm{~kg}$

FIGURA 23-Sistema construtivo D. Mossas produzidas pelos impactos 58

FIGURA 24-Sistema construtivo convencional - padrão COHAB.

Arrancamento do sistema de fixação com $600 \mathrm{~N}$ de carga total

FIGURA 25-Sistema construtivo B. Vista do ensaio com carga total aplicada de $1000 \mathrm{~N}$

FIGURA 26-Sistema construtivo J. Face oposta da parede instrumentada 64

FIGURA 27-Sistema construtivo H. Empenamento da prancha no ponto de fixação dos dispositivos de aplicação das cargas 65

FIGURA 28-Sistema construtivo convencional - padrão COHAB.

Vista do ensaio 68

FIGURA 29-Sistema construtivo D. Vista do ensaio 68

FIGURA 30-Sistema construtivo convencional - padräo COHAB.

Dispositivo para marcar a inclinação da porta de $60^{\circ}$ com o plano da parede 69

FIGURA 31-Sistema construtivo F. Detalhe da ruptura da folha no $7^{\circ}$ fechamento brusco .70

FIGURA 32-Sistema construtivo $\mathrm{C}$. Detalhe das fissuras painel/marco na região de fixação do marco 
FIGURA 33-Sistema construtivo I. Detalhe da ruptura da solda no canto inferior da folha 72

FIGURA 34-Sistema construtivo $\mathrm{H}$. Detalhe da fissura na prancha durante o $8^{\circ}$ fechamento brusco

FIGURA 35-Avaliação dos sistemas construtivos em relação ao padrão COHAB. Ensaio de impactos de corpo mole de grande dimensão - $1^{\circ}$ impacto de $240 \mathrm{~J}$

FIGURA 36-Avaliação dos sistemas construtivos em relação

ao padrão COHAB. Ensaio de impactos de corpo mole de grande dimensão - $3^{\circ}$ impacto de $240 \mathrm{~J}$ .76

FIGURA 37-Avaliação dos sistemas construtivos em relação ao padrão COHAB. Ensaio de impactos de corpo duro de pequena dimensão .78

FIGURA 38-Avaliação dos sistemas construtivos em relação ao padrão $\mathrm{COHAB}$. Ensaio de cargas provenientes de peças suspensas - deformaçōes instantâneas

FIGURA 39-Avaliação dos sistemas construtivos em relação ao padrão $\mathrm{COHAB}$. Ensaio de cargas provenientes de peças suspensas - deformações residuais

FIGURA 40-Procedimento do ensaio 85

FIGURA 41-Ensaio em campo 85

FIGURA 42-Porcentagem dos níveis de qualidade em relação ao ensaio de impactos de corpo mole de grande dimensão 89

FIGURA 43-Porcentagem dos níveis de qualidade em relação ao ensaio de impactos de corpo duro de pequena e grande dimensão 90

FIGURA 44-Porcentagem dos níveis de qualidade em relação ao ensaio de cargas provenientes de peças suspensas 90

FIGURA 45-Porcentagem dos niveis de qualidade em relação ao ensaio de fechamento brusco de portas 


\section{LISTA DE TABELAS}

TABELA 01-Resumo dos resultados referentes ao ensaio de impactos de corpo mole de grande dimensão

TABELA 02-Resumo dos resultados referentes ao ensaio de impactos de corpo duro de pequena e grande dimensão

TABELA 03-Resumo dos resultados referentes ao ensaio de cargas provenientes de peças suspensas

TABELA 04-Resumo dos resultados referentes ao ensaio de fechamento brusco de portas

TABELA 05-Ensaio de impactos de corpo mole 240J -

$1^{\circ}$ impacto

TABELA 06-Ensaio de impactos de corpo mole 240J $3^{\circ}$ impacto

TABELA 07-Ensaio de impactos de corpo duro de pequena dimensão

TABELA 08-Ensaio de impactos de peças suspensas deformações instantâneas

TABELA 09-Ensaio de impactos de peças suspensas deformações residuais

TABELA 10-Avaliação dos sistemas em relação ao padrão

COHAB - ensaio de fechamento brusco de portas

TABELA 11-Avaliação dos sistemas construtivos empregados na Vila Tecnológica de Ribeirão Preto 84

TABELA 12-Porcentagem dos niveis de qualidade em relação aos ensaios realizados 


\section{LISTA DE SIGLAS}

$\begin{array}{ll}\text { BNH } & \text { - Banco Nacional de Habitação } \\ \text { CFIA } & \text { - Conselho Federado de Ingenieros y de Arquitectos } \\ \text { COHAB } & \text { - Cia. Habitacional Regional } \\ \text { CSTB } & \text { - Centre Scientifique et Techinique du Bâtiment } \\ \text { CSTC } & \text { - Centre Scientifique et Techinique de la Construction } \\ \text { DIN } & \text { - Deutscher Normanausschuss } \\ \text { EPUSP } & \text { - Escola Politécnica da Universidade de São Paulo } \\ \text { IPT } & \text { - Instituto de Pesquisas Tecnológicas } \\ \text { ISO/DP } & \text { - International Organization For Standardization/Draft Proposal } \\ \text { NBI } & \text { - Norwagian Building Research Institute } \\ \text { NBR } & \text { - Norma Brasileira Registrada } \\ \text { NBS } & \text { - National Bureau of Standards } \\ \text { OCC } & \text { - Oficina de Controle de Qualidade } \\ \text { ONNUM } & \text { - Oficina Nacional de Normas y Unidade de Medida } \\ \text { PRONATH } & \text { - Programa Nacional de Tecnologia da Habitação } \\ \text { PROTECH } & \text { - Programa de Difusão de Tecnologia para Construção de } \\ & \text { Habitação de Baixo Custo } \\ \text { UEAtc } & \text { - Union Européenne Pour L'ágrément Techinique Dans La } \\ & \text { Construction }\end{array}$




\section{RESUMO}

OLIVEIRA, F.L. Avaliação do desempenho estrutural de sistemas construtivos inovadores: estudo de caso. São Carlos, 1996. 108p. Dissertação (Mestrado) - Escola de Engenharia de São Carlos, Universidade de São Paulo.

Aborda-se a importância da avaliação de desempenho em sistemas construtivos inovadores, relatando inicialmente os sistemas de avaliação utilizados em alguns países estrangeiros e também, no Brasil. As edificações térreas de uso unifamiliar devem satisfazer determinadas exigências dos usuários, dentre as quais aquelas de segurança estrutural, durabilidade e estanqueidade. Para cada uma destas exigências estão estabelecidos requisitos e critérios de desempenho que devem ser atendidos quando o produto for avaliado. Tendo como objetivo a avaliação estrutural de sistemas construtivos inovadores, tomou-se como estudo de caso a Vila Tecnológica de Ribeirão Preto, com 111 habitações distribuídas em onze sistemas construtivos inovadores, implantada através do projeto PROTECH, programa instituído pela secretaria Geral da Presidência da República, e da COHAB-RP. O objetivo do empreendimento é criar centros de experimentação, demonstração e difusão de inovações tecnológicas, incentivando a produção industrial, aliando redução de custos à melhoria da qualidade da habitação. Cada sistema construtivo foi submetido a ensaios, realizados no campo, em um protótipo escolhido aleatoriamente. Para comparação e controle dos resultados, uma habitação convencional, "padrão COHAB", foi submetida aos mesmos ensaios, servindo como valores de referência. Apresentam-se então os resultados da avaliação, referentes à segurança estrutural, como também, a metodologia utilizada e o desempenho de cada sistema inovador frente ao padrão de referência adotado.

Palavras-chave: avaliação de desempenho, sistemas inovadores, segurança estrutural. 


\section{ABSTRACT}

OLIVEIRA, F.L. Structural performance evaluation of innovative construction systems: case of study. São Carlos, 1996. 108p. Master Degree Thesis Escola de Engenharia de São Carlos, Universidade de São Paulo.

This work discusses the performance evaluation of innovative construction systems, starting with an account of the evaluation systems used in Brazil as well as in some foreign countries. Single storey one-family houses must satisfy several of the users' basic expectations, among them structural safety, durability and watertighness. Prerequisites and performance criteria to satisfy each of these expectations have been established and must be met when the product is evaluated. The "Vila Tecnológica de Ribeirão Preto" was taken as a case study to perform a structural evaluation of innovative construction systems. The "Vila Tecnológica" has 111 homes distributed under eleven innovative construction systems, built through the PROTECH project, a program instituted by the Secretaria Geral da Presidência da República (General Bureau of the Presidency of the Republic) and by COHAB-RP (a federal housing program for low income families). The aims to create centers for project experimention, demonstration and dissemination of innovative building technologies, and to stimulate production on an industrial scale, combining the advantages of reduced costs to improved housing quality. Each construction system was submitted to field tests performed on a randomly selected prototype. For purposes of comparison and control of the results, a conventional "standard COHAB" house was submitted to the same tests, the results thereof serving as reference values. The results of the evaluation of structural safety are presented herein, as well as the methodology utilized and the performance of each innovative construction system compared to the standard of reference adopted.

Keywords: housing, performance evaluation, innovative construction systems, structural safety. 


\section{INTRODUÇÃO}

Com a racionalização e a industrialização da construção civil, que tornaram possível o aparecimento de novos produtos e métodos construtivos, surgiram também questöes relevantes como a de avaliar estas soluções inovadoras, que atualmente vêm se destacando principalmente na edificação de habitações populares.

As primeiras habitações populares inovadoras, financiadas pelo extinto BNH (Banco Nacional de Habitação), foram introduzidas, sem que antes fossem submetidas a uma avaliação técnica para prever seu comportamento. Na verdade, foi a construção do conjunto de Itaquera em São Paulo, em meados da década de 70 , que serviu de grande laboratório para novas tecnologias sendo empregados diferentes sistemas construtivos distribuídos em 31.860 unidades. Os erros e acertos dessa experiência, no entanto, só foram avaliados depois dos edifícios concluídos e habitados, ALMEIDA (1984).

Um fator relevante a ser considerado é a falta de uma normalização onde os fabricantes e construtores pudessem se basear. Levando em consideração o conceito de normalização, citado nas notas de aula da EPUSP (1998), que é a atividade do estabelecimento das normas, onde estas fixam as definições, características (dimensões, qualidades), métodos de ensaio, regras de emprego, etc, houve um grande interesse em normalizar a avaliação de desempenho para que os fabricantes, desses sistemas novos, pudessem garantir a qualidade do produto final. Segundo FOSTER (1970), "com o avanço significativo dentro da tecnologia na construção civil, novos materiais estão sendo desenvolvidos, antigos materiais estão sendo colocados para novas utilidades e 
componentes de novos e antigos materiais estão sendo desenvolvidos, como por exemplo, os painéis sanduíches. Isto faz com que as exigências na "performance" destes produtos se tornem muito maiores". Sendo assim, a produção de componentes e novos sistemas construtivos nos países europeus, sempre foi acompanhada pela criação de uma retaguarda tecnológica, ou seja, ao mesmo tempo que era desenvolvida a mentalidade industrial na construção, surgia a consciência da avaliação do desempenho e do controle da qualidade na execução das obras, ALMEIDA (1984).

O primeiro sistema moderno de avaliação, que foi estabelecido na Europa foi o Sistema de Aprovação Francês, desenvolvido para reduzir as restrições no que se refere a introdução de construções inovadoras. Estabelecido por um decreto do Ministro da Construção, o Sistema, é dirigido pelo CSTB (Centre Scientifique et Techinique du Bâtiment), uma organização do governo federal.

O pedido para se obter um certificado de aprovação, fornecido apenas para sistemas construtivos novos, deve vir de um fabricante ou construtor, e no formulário deve citar especificadamente a área de aplicação e método de uso. As amostras são submetidas a testes ou experimentos, em oficinas, fábricas, laboratórios ou no local de trabalho e a avaliação baseiase na segurança, utilidade e durabilidade, levando em conta as condições climáticas e regulamentações da construção.

A emissão de um certificado é feita pelo diretor do CSTB e tem validade de três anos. Depois desse prazo tem que ser renovado, embora um certificado oficial possa ser estabelecido, caso não haja variações nos resultados e seus valores sejam satisfatórios. Esta renovação é feita para que o fabricante possa modificar e melhorar seu produto, continuamente, mas mudanças no material ou processo, durante a validade do certificado, deverão ser submetidos a uma reavaliação para renovar o certificado.

$\mathrm{Na}$ Inglaterra o Conselho de Aprovação foi estabelecido pelo Ministério do Trabalho e Construção, que é responsável por $50 \%$ da habitação no país. O Ministério desejava desenvolver procedimentos para 
testar o desempenho e promover maior aceitação de construções inovadoras.

A avaliação é direcionada principalmente a aspectos técnicos e não lida com aspectos arquitetônicos ou de uso econômico. O certificado é interpretado como uma tentativa de fornecer a garantia de que um produto novo e desconhecido terá um desempenho satisfatório, quando for usado na construção.

O Conselho de Aprovação depende de um outro órgão do governo, o Building Research Station, que possui um grupo de técnicos para desenvolver os testes requeridos que, podem ser feitos em outros laboratórios do governo, e hoje provavelmente em universidades. Os testes são realizados, os resultados analisados e o conselho de aprovação toma uma decisão final. $\mathrm{O}$ certificado é válido por 3 anos podendo ser renovado por um período adicional. 0 produto pode ser modificado, desde que o conselho seja comunicado e concorde que tais mudanças não tornam inválidas o valor do certificado.

O sistema de aprovação na Holanda é feito pelo Ratiobouw, que não possui laboratório e depende das universidades para seus testes. $\mathrm{Na}$ emissão do certificado de aprovação difere do sistema francês, pois o Ratiobouw é que faz a recomendação aos comitês e a emissão é feita pelos mesmos. Existem comitês preparados para diversas áreas como piso, teto, etc. $O$ certificado é exigido em habitações patrocinadas pelo governo que chega a $80 \%$ do total.

Na Dinamarca o sistema de aprovação é feito pelo Danish National Institute of Building Research. As avaliações são feitas em laboratórios próprios ou também em laboratórios aprovados dentro de industrias e universidades. São realizadas aproximadamente 100 aprovações por ano. A aprovação é cedida por um certo período mas, pode ser renovada apenas uma vez, seguida de um documento permanente e negada, se o produto tiver desempenho insuficiente, se é meramente para finalidade de divulgação, se são mudanças muito pequenas ou se é para usar apenas uma vez. A National Test Station, outra instituição do governo, é 
responsável por classificar ou qualificar os produtos quanto às exigências de aprovação trabalhando junto com o Danish National Institute of Building Research.

O certificado de qualidade na Noruega é emitido pelo "Norwagian Building Research Institute" (NBI) e foi desenvolvido especialmente para assegurar a qualidade de materiais e componentes usados na construção. Quando o fabricante solicita o certificado, o processo de fabricação do produto é inspecionado e protótipos são ensaiados. Em casos especiais, uma segunda inspeção pode ser feita. A obtenção de um certificado de qualidade $\mathrm{NBI}$, para um produto lançado no mercado, é a garantia da responsabilidade do fabricante em fazer produtos da mesma qualidade das que foram testadas, analisadas e aprovadas pelo Instituto. Se houver alguma mudança na fabricação, um novo protótipo é ensaiado.

$\mathrm{Na}$ Alemanha, uma agência central de aprovação, Zulassung (homologação, certificado), foi estabelecida antes de 1900. Depois da $2^{\mathrm{a}}$ guerra mundial, a função de aprovação foi transferida para os estados. Testes e avaliações são feitas em laboratórios de várias universidades. Como nos paises já citados, Zulassung se interessa em avaliar inovações pois, materiais tradicionais estão incluídos nas especificações de Deutscher Normanausschuss (DIN).

Observa-se pelas descrições acima, que os sistemas de aprovação entre os paises têm muito em comum. Isto proporcionou o estabelecimento de uma União Oficial de Sistemas de Aprovação - UEAtc (Union Européenne pour L'ágrément Techinique dans La Construction). Os países membros da União são França, Inglaterra, Itália, Bélgica, Holanda, Portugal e Espanha. O certificado recebido em um país não tem necessariamente garantia em um outro país membro da União, cada país membro retém o direito de decidir tais assuntos.

As construções industrializadas podem se tornar dominantes, nos países desenvolvidos, em um futuro muito próximo. Por isso, na América do Norte, as normas de construção foram revisadas considerando essa tendência. Inicialmente elas tratavam com maior ênfase os perigos 
causados pelo fogo. Hoje, tratam com mais importância a proteção do usuário.

Em 1937 foi decidido que o governo do Canadá, por meio do National Research Council e do Department of Finance, formulasse um "modelo" de normas de construção que fosse publicado como um documento consultivo. A primeira edição foi publicada em 1941 e em 1948 o National Research Council assumiu toda responsabilidade pelas normas e criou o "Associate Committe" do "National Building Code", com a tarefa de manter as normas atualizadas com o desenvolvimento da tecnologia na construção. Mais tarde, outras edições também foram publicadas, em 1953, 1960 e 1965, sendo então decidido, a partir desta última edição, outras novas em intervalos de 5 anos.

Os problemas que serviram de base para a formação do National Building Code foram: a proteção dos usuários com a segurança estrutural, a prevenção ao fogo e perigos à saúde. Levantou-se então a questão de que a prevenção ao fogo e perigos à saúde poderiam ser tratados separadamente pois, pouco afetam o modo como o prédio é construído. Concluiu-se, portanto, que as normas estruturais é que eram influenciadas pelos métodos construtivos. Sob esse ponto de vista e a ampliação do uso de pré - fabricados na construção civil, surgiu uma pergunta fundamental para elaboração das normas: habitações produzidas em fábricas devem ser submetidas às mesmas normas que são aplicadas às habitações de métodos tradicionais? A resposta foi: porque não? Já que a segurança do usuário está baseada nas normas adotadas. As exigências devem ser as mesmas para qualquer componente ou sistema estrutural, se pré - fabricado ou não.

Segundo LEGGET (1965), as normas de construção devem fugir das especificações antigas e tenderem muito mais em direção às normas de desempenho. Isto originará novos sistemas construtivos que serão desenvolvidos com o aumento da industrialização, com igual chance de competição com os métodos tradicionais tão bem aceitos. As exigências estruturais contudo, podem tornar-se bem mais flexíveis pela introdução do 
conceito de desempenho, ao invés de aderirem a um tipo de estrutura especifica.

Pelas normas canadenses (Canadian Code), o fabricante de um sistema construtivo proposto, deve submetê-lo a ensaios ou a qualquer outra avaliação para provar que seu produto satisfaz às exigências de desempenho do "código". Na verdade essas regulamentações não limitam o progresso na construção e nem restringem as inovações de sistemas mas, são exigidas para proteção do usuário.

Saindo do âmbito de Primeiro Mundo e exemplificando a avaliação em um país em desenvolvimento, a Costa Rica, ao contrário do que se imagina, possui a maioria das habitações de baixo custo, construídas através de sistemas de tecnologia industrializada. A Oficina Nacional de Normas y Unidades de Medida (ONNUM), órgão do Ministério da Economia, Indústria e Comércio é encarregada da normalização e controle de qualidade dos produtos fabricados no país. No entanto, a lei de Construção Civil da Costa Rica, concede o direito de também normalizar e regular os materiais e sistemas construtivos ao Conselho Federado de Ingenieros y de Arquitectos (CFIA) e que, além disso, pode proibir o uso dos produtos que não atendam as normas mínimas exigidas.

O CFIA criou uma Comissão de Qualidade, que é órgão assessor da Oficina de Controle de Qualidade(OCC), para analisar os sistemas construtivos, determinando se o mesmo pode ou não ser utilizado.

A prática da avaliação neste país, é feita para desenvolver, produzir e manter um produto de qualidade que seja econômico e mais útil, sendo sempre satisfatório para o usuário. A avaliação deve garantir a resistência e a durabilidade do produto e pode ser teórica (cálculos estruturais) e prática (ensaios de campo ou laboratório).

No Brasil, porém, as inovações não vieram acompanhadas com a mesma mentalidade que os países europeus. Normalmente os sistemas eram avaliados somente pelos seus custos iniciais, não sendo computados os custos de operação e nem mesmo os de manutenção e/ou recuperação, 
ficando relegada a segundo plano a preocupação com os aspectos de durabilidade e vida útil dos edifícios, ALMEIDA (1984).

Os problemas da construção habitacional brasileira começaram a ser analisados quando o BNH firmou convênio com o IPT para estudar formas de avaliar o desempenho das edificações construídas. Hoje, a avaliação de desempenho é uma prática que vem se consolidando cada vez mais na construção civil, tendo como objetivo não só garantir os componentes durante sua vida útil, mas o edifício como um todo.

$\mathrm{Na}$ década de 80, a Divisão de Edificações do Instituto de Pesquisas Tecnológicas do Estado de São Paulo - IPT, introduziu no país o conceito de desempenho associado às condições de exposição e, principalmente, às necessidades do usuário, NEVES (1993).

Juntamente com o Banco Nacional de Habitação - BNH, o IPT realizou projetos como "Formulação de Critérios para Avaliação de Desempenho de Habitações" e "Normalização de Interesse da Construção de Habitações" que deu origem ao considerado "guia" para avaliação de desempenho "Avaliação de Desempenho de Habitações Térreas Unifamiliares".

Baseados neste relatório, que se destina à avaliação e ao desenvolvimento de soluções inovadoras para habitações térreas, no que se refere a seus elementos e às suas instalações, é que no Brasil são feitas as avaliações de desempenho de soluções inovadoras para habitações térreas unifamiliares. Para isso, determina os métodos de avaliação a serem utilizados na verificação do atendimento aos requisitos e critérios de desempenho estabelecidos.

Neste trabalho, aborda-se a avaliação de sistemas construtivos, alternativos, através do seu desempenho quanto à segurança estrutural, em confronto com o desempenho de habitações, destinadas às faixas de baixa renda, edificadas com materiais e processos convencionais de construção, tendo como estudo de caso, a avaliação da segurança estrutural de sistemas construtivos empregados na construção da Vila Tecnológica de Ribeirão Preto. 
Pretende-se ainda, sugerir algumas alterações nos procedimentos dos ensaios executados em campo e nos equipamentos utilizados, procurando simplificar a realização dos mesmos.

Em uma primeira parte do trabalho (capítulos 2 e 3) é mostrado um histórico do conceito de desempenho, bem como, a metodologia empregada para avaliação de novos sistemas construtivos.

No capítulo 4, a avaliação de desempenho é especificada quanto à segurança estrutural onde são demonstrados os requisitos e critérios de desempenho e os métodos de avaliação estrutural.

Em uma segunda parte do trabalho (capítulo 5), que se refere à parte prática, é mostrada a avaliação estrutural de 10 sistemas construtivos inovadores frente a um sistema construtivo convencional adotado. 


\section{HISTÓRICO}

O uso da expressão "performance requirement" foi abordada em países estrangeiros, no início da década de 60 no $2^{\circ}$ congresso do Internacional Council for Building Research Studies and Documentation CIB, pelo então diretor do Building Research Station, LEA (1962), que relaciona o conceito aplicado ao edifício. Nos congressos posteriores, o assunto é novamente abordado por SNECK e BLACH (1965) e em 1968 por MATHEY \& REICHARD que avalia o desempenho de paredes externas através de ensaios de compressão.

Em 1965, o CSTB (Centre Scientifique et Technique du Bâtiment) implanta regras de qualidade à novos sistemas quando publica "Directives Communes Pour L'Agrément des Maison Légères".

Com o incremento da industrialização na construção civil uma preocupação maior com a avaliação de construções inovadores é verificada, quando, então, FOSTER (1970) publica o artigo "European Systems for Evaluation and Approval of Innovations in Buildings" descrevendo a avaliação de desempenho de sistemas utilizados em seis paises europeus.

GIBSON (1977) sugere que o conceito de desempenho seja uma forma de fixar o que se espera do comportamento de um produto manufaturado e, cita alguns países onde as especificações de desempenho foram aplicadas na construção de habitações; por exemplo, alguns sistemas na Noruega, outros na Bélgica e na Inglaterra e, a operação Breaktrough nos Estados Unidos, onde foram avaliados sistemas construtivos inovadores destinados a construção de habitaçōes, coordenada pelo National Bureau of Standards - NBS.

O CSTB publica em 1994 "Les documents interprétatifis de la 
Directive européene sur les produits de construction". São 6 textos (documentos) contendo individualmente exigências essenciais como: resistência mecânica e estabilidade; segurança de utilização; segurança em caso de incêndio; higiene, saúde e meio ambiente; proteção contra ruídos; economia de energia e isolação térmica.

No Brasil, ROSSO publica, na década de 70, a primeira proposta de avaliação de desempenho no Brasil. Sugere que a tarefa de verificar individualmente $\circ$ desempenho de materiais, componentes, processos construtivos, etc, deve ser feito por um órgão colegiado que possa realizar essa tarefa através de uma estrutura constituída de entidades de normalização e pesquisas, destinando-se a garantir e a registrar esse desempenho em certificados de homologação.

Para SOUZA (1981) os certificados de homologação não garantem integralmente a qualidade do produto, mas é apenas uma avaliação técnica favorável, objetivando que todo produto novo lançado no mercado, seja submetido a um estudo técnico rigoroso com a finalidade de melhor caracterizar seu desempenho e sua utilização.

Segundo ALMEIDA (1984), a avaliação de desempenho de sistemas precisa vir acompanhada do controle de qualidade no processo de produção do produto final pois, um sistema avaliado no laboratório, na prática pode não corresponder aos resultados obtidos nos ensaios, por vários motivos, inclusive pela falta de controle sistemático nas fases de projeto e execução das edificações. O IPT sugere então, a implantação de uma sistemática de controle em todas as etapas do processo: planejamento, projeto, fabricação de materiais e componentes e execução.

Para SOUZA (1988), a avaliação de novos sistemas por comparação com métodos tradicionais, é um paradigma duvidoso pois, embora este esteja empiricamente aprovado, pode estar super dimensionado para alguns aspectos e regiões do país ou subdimensionado para outros.

THOMÁZ (1993) sugere que se estabeleça requisitos técnicos classificatórios pela relação custo/benefício, e um sistema de pontuação 
técnica que identifique os incrementos de qualidade inerentes a cada sistema construtivo.

CAVANI (1993) propõe que cada critério classificatório receba uma pontuação, que traduza a sua importância relativa ao desempenho global do sistema construtivo, e caso o mesmo não atenda a algum critério eliminatório seja colocado fora de uso. O desempenho do sistema construtivo será representado por um índice obtido pela divisão do custo global (inicial + manutenção) com a pontuação obtida. Assim, o melhor sistema construtivo será aquele que apresente o índice menor.

SOUZA (1989) observa que nos últimos anos houve uma tendência de atualização tecnológica na construção civil e nesse processo, três linhas de atuação se interagem de forma bastante dinâmica: a modernização tecnológica via racionalização de processos, o desenvolvimento de inovações tecnológicas e a melhoria da qualidade (Figura 01). Essa interação pode ser interpretada como: com a modernização na construção civil pode-se desenvolver sistemas construtivos novos com maior qualidade. $\mathrm{Na}$ qualidade, cinco diretrizes orientam essa linha de atuação: normalização técnica, controle de qualidade do projeto, fabricação e execução, certificado de conformidade, homologação e garantia da qualidade. Analisando-se essas diretrizes e considerando-se que seu atendimento depende de uma avaliação prévia do produto, propõem-se a fusão de mais uma linha de atuação, caminhando junto com a linha de qualidade - a linha da avaliação. Essa fusão merece destaque pois, avaliando o produto é que se pode garantir e melhorar sua qualidade (Figura 02).

A inserção do conceito de desempenho destinado à avaliação do edifício traz contribuições no campo do desenvolvimento de produtos, na elaboração de projetos, na normalização e no controle de qualidade. 


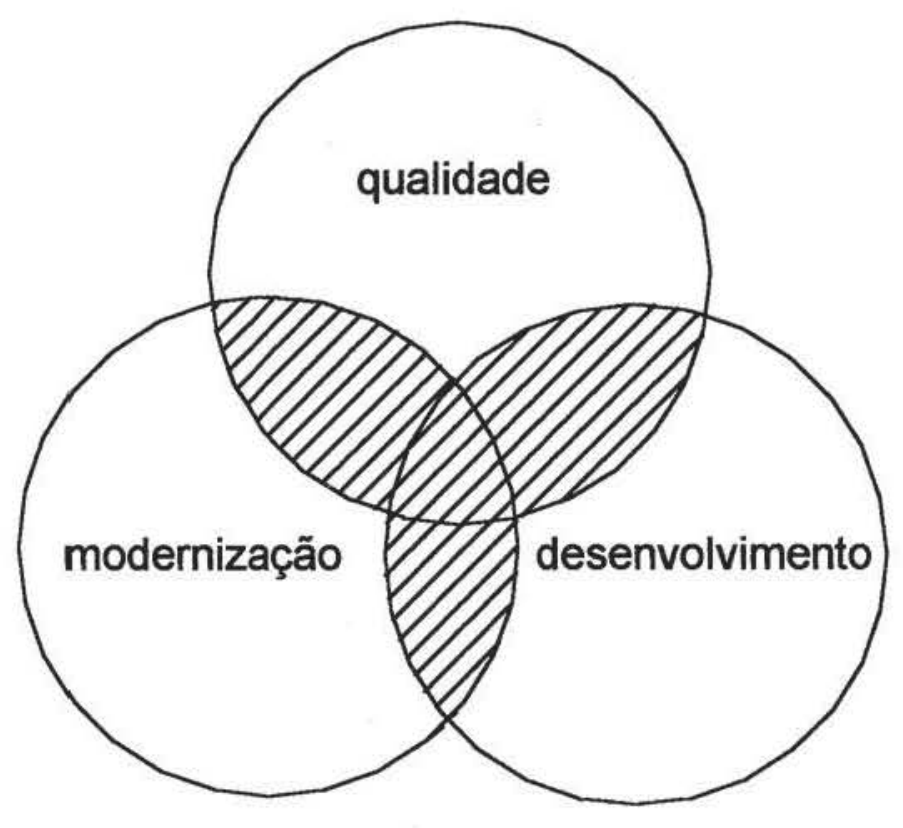

Figura 01 - Interação entre linhas de atuação - extraída de SOUZA (1988).

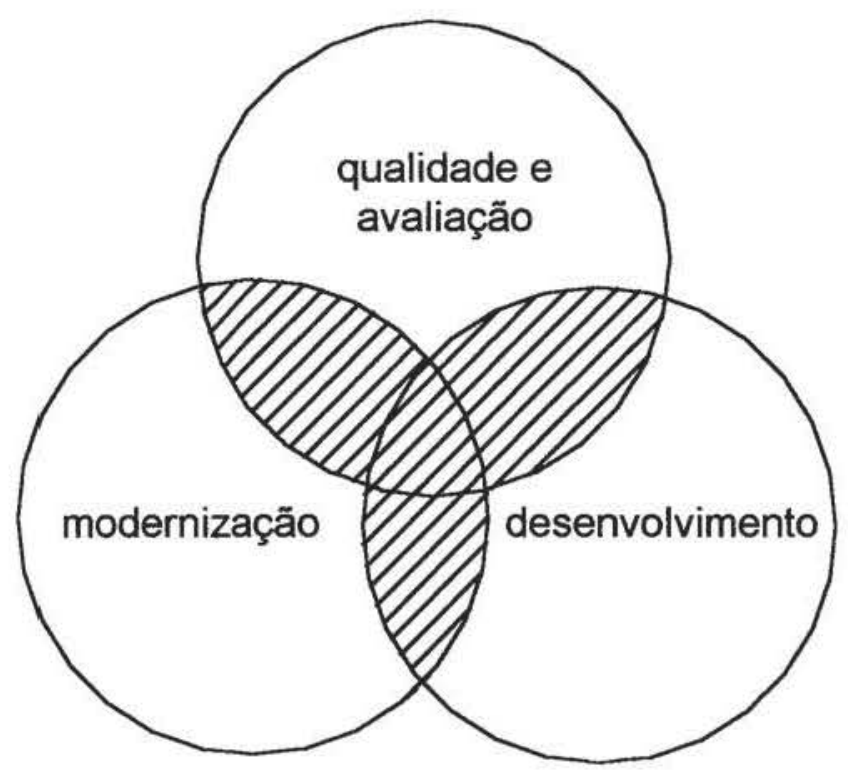

Figura 02 - Proposta de interação entre linhas de atuação. 


\section{METODOLOGIA DA AVALIAÇÃO DE DESEMPENHO}

Visando a modernização da construção habitacional e conseqüente redução de custos e perdas, com o aumento da produtividade, algumas empresas têm empreendido esforços, tanto na racionalização de sistemas construtivos convencionais, como no desenvolvimento de novos sistemas, REIS \& BASTOS (1994).

Os processos construtivos viabilizam, através da tecnologia e da técnica, a materialização das unidades habitacionais, ou seja, definem as formas e as capacidades técnicas e econômicas de se construir. Estes processos estabelecem tipologicamente as tecnologias a serem aplicadas, fazendo com que, nos projetos surjam os sistemas construtivos e na produção das unidades habitacionais se definam os processos de trabalho (a maneira de fazer), MARTUCCI (1990). Este processo pode ser esquematicamente mostrado na figura 03.

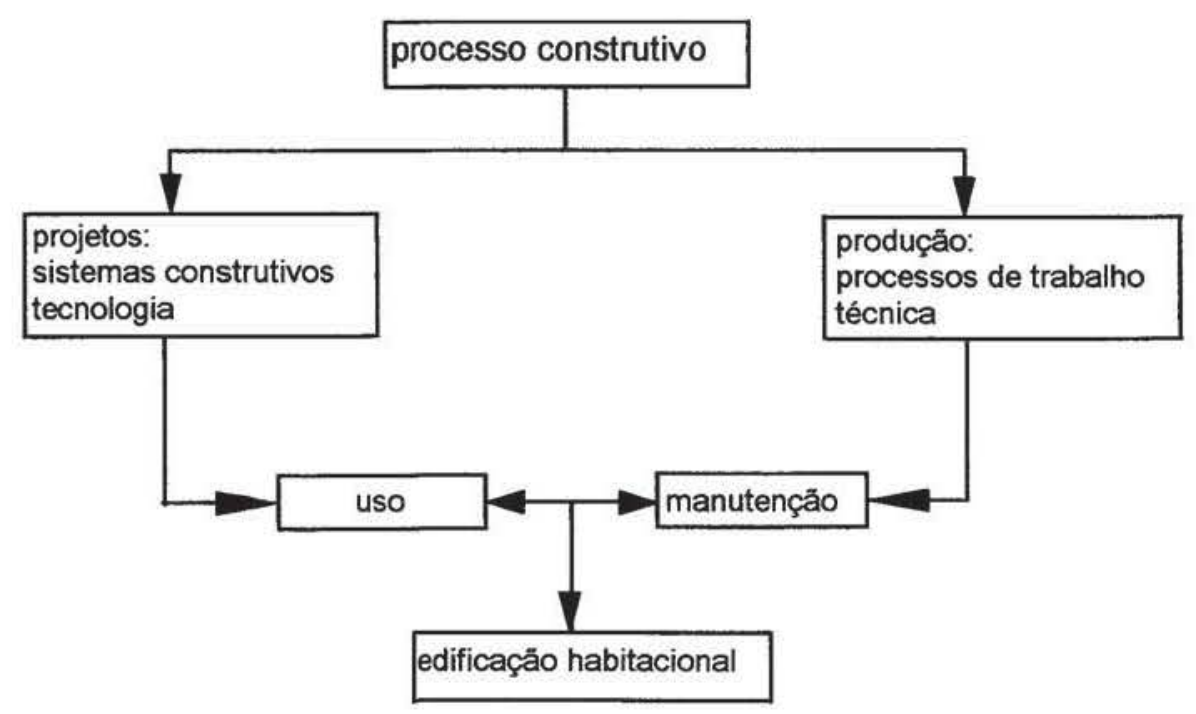

Figura 03 - Esquema dos processos construtivos - extraída de MARTUCCI (1990). 
Considerando-se que as construçőes convencionais empregam métodos que são aceitos como prática comum por um longo período de tempo e chamando-as de "tradicionais", ao evoluírem tecnologicamente, estes sistemas sofrem transformaçőes no seu processo de execução $e$, conseqüentemente, o produto final passa a apresentar características bem distintas do inicial, DUARTE (1981).

Este caminho percorrido é chamado de "Rota de Transformação" ou "Caminho de Evoluçäo" (Figura 04), e em qualquer sistema consiste em: constatar os defeitos relevantes no atual sistema e os motivos da sua existência; buscar tipos novos de componentes de sistemas visando retirar as imperfeições do sistema atual $\theta$, descobrir a seqüência de modificações que permita aos componentes considerados se desenvolverem ou serem permutados por outros.

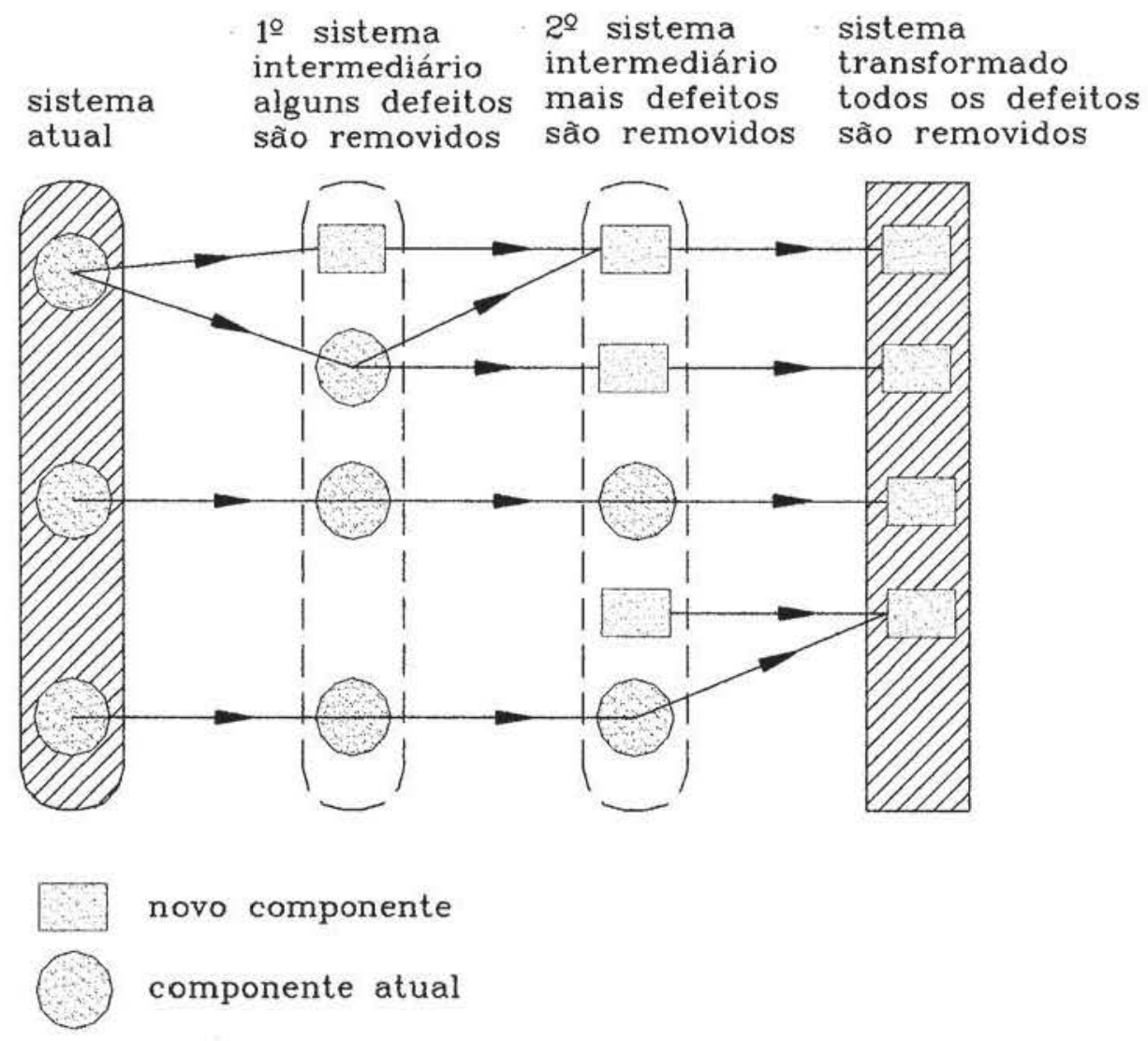

Figura 04 - "Rota de Transformação" ou "Caminho de Evolução" extraída de DUARTE (1982). 
Como o déficit habitacional entre a população de baixa renda é um problema marcante no país e procurando solucionar esta questão surgem "organismos com objetivos de planejar, construir e financiar habitações destinadas às faixas mais carentes da população, bem como criar e incentivar 0 desenvolvimento de programas e novas tecnologias de construção em massa, para que, no mais curto prazo, o brasileiro de baixa renda pudesse atingir o sonho de morar com dignidade", MACHADO JR (1991).

Como exemplo temos o projeto BRA 85/005 (1985) - Reconstrução e Reabilitação das Áreas Inundadas do Nordeste, Projeto Modelar (1985) Companhia Metropolitana de Habitação de São Paulo - COHAB-SP onde foram estabelecidos dois canteiros experimentais, resultando em 71 unidades habitacionais que reuniram as mais diversas soluções: em alvenaria autoportante, alvenaria estrutural, paredes moldadas no local com auxilio de fôrmas metálicas e emprego de pré-moldados, Projeto $\mathrm{ABCP}$ (1990) - Associação Brasileira de Cimento Portland - SP que desenvolveu um projeto de moradia evolutiva mais conhecida como embriâo e, recentemente o PRONATH e o PROTECH com suas Vilas Tecnológicas que são centros de experimentação, demonstração e difusão de inovaçöes tecnológicas incentivando a produção industrial, aliando a redução dos custos à melhoria de qualidade das habitações e que atualmente estão sendo construídas em várias cidades como: Curitiba, Ribeirão Preto e Bauru.

Para THOMÁZ (1993), as construções populares brasileiras devem se adaptar à real disponibilidade de recursos das populações mais carentes mas, não devem ser regulamentadas inferiorizando a qualidade pelo simples fato de serem destinadas a pessoas pobres. Mas, o que se observa é que muitos novos produtos lançados no mercado de habitações não sofreram um julgamento quanto à eficácia de sua tecnologia o que acarreta problemas patológicos como fissuras, umidade, etc, afetando a durabilidade do produto. Como atualmente a tecnologia, a nível de produção, de sistemas inovadores no campo da habitação popular é considerada 
significante, surge a necessidade da avaliação dessas inovações e da incorporação de seus resultados ao produto final.

Segundo MITIDIERE FILHO \& SOUZA (1994), a avaliação de desempenho deve prever o comportamento do edifício, componentes e instalações, quando submetidas a condições normais de exposição e avaliar se tal comportamento satisfaz as exigências do usuário. Entende-se por condições de exposição o conjunto de ações atuantes sobre um determinado produto durante sua vida útil como por exemplo: vento, impactos, etc. As exigências do usuário são interpretadas como as necessidades que devem ser satisfeitas pelo edifício a fim de que este cumpra sua função como: segurança estrutural, estanqueidade, etc.

A avaliação de desempenho é fundamentada em requisitos, critérios e métodos de avaliação que permitem constatar se o edifício e seus componentes obedecem às condições exigidas. A metodologia empregada na aplicação do conceito de desempenho à avaliação da construção pode ser resumida no fluxograma apresentado a seguir:

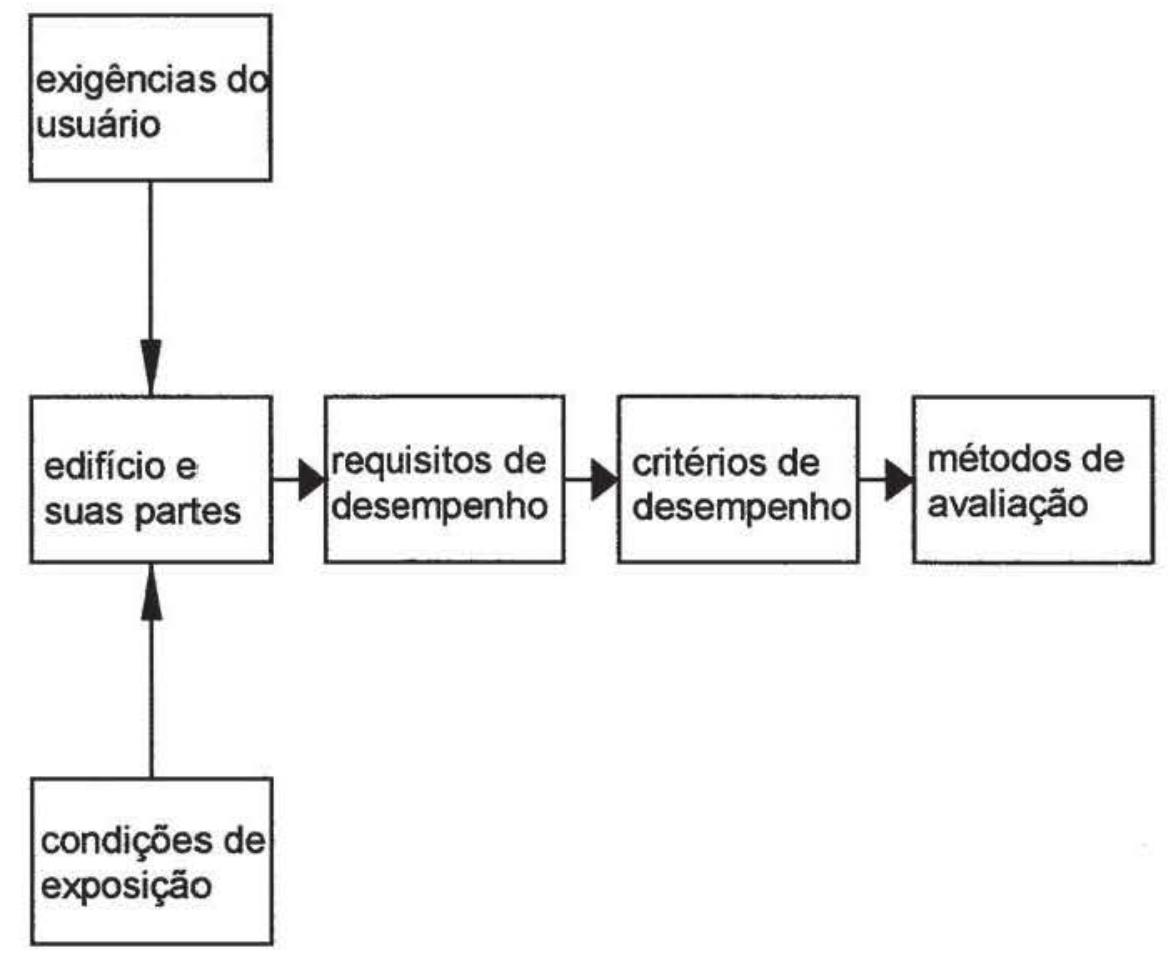

Figura 05 - "Processo de Avaliação de Desempenho" - extraída de SOUZA (1983). 


\subsection{Requisitos e critérios de desempenho}

Segundo MITIDIERE FILHO \& SOUZA (1994), os requisitos e critérios são entendidos como condições qualitativas e quantitativas, respectivamente, às quais um determinado produto deve atender quando submetido às condições de exposição, a fim de que sejam satisfeitas as exigências do usuário. São interpretados como níveis de segurança, habitabilidade e durabilidade, que 0 produto deve atender quando submetido a ações.

Para a avaliação da segurança estrutural foram fixados as exigências, visando garantir que, os elementos da habitação não atinjam o estado limite último, correspondente à ruína por ruptura, por deformação excessiva ou por instabilidade, e o estado limite de utilização, estado correspondente às fissuras inaceitáveis prejudiciais ao uso ou à durabilidade da peça e às deformações que ultrapassam os limites aceitáveis para utilização da estrutura, NBR 8681 (1984).

A primeira etapa para se realizar uma avaliação é o conhecimento qualitativo dos requisitos de desempenho. Os critérios por sua vez, são a quantificação desses requisitos já expressos qualitativamente. Para referida tarefa, as exigências do usuário e as condições de exposição devem estar previamente caracterizadas.

Os requisitos e critérios são estabelecidos pelas instituições de cada país como o CSTC (Centre Scientifique et Techinique de la Construction) na Bélgica que editou uma série de documentos técnicos: Guide de Performance du Bâtiment, CSTC (1980). O CSTB (Centre Scientifique et Techinique du Bâtiment) na França que usa o conceito de desempenho para implantar sistemáticas de controle de qualidade de novos componentes e sistemas construtivos e o IPT (Instituto de Pesquisas Tecnológicas) no Brasil que elaborou um documento onde aborda o procedimento de avaliação de desempenho.

A experiência que o IPT tem acumulado na avaliação de sistemas construtivos inovadores, tem mostrado que deve-se ter critérios 
eliminatórios e classificatórios. Os eliminatórios seriam os critérios relacionados com a segurança, habitabilidade e durabilidade, enquanto que, os classificatórios aqueles que acrescentariam qualidade ao sistema como melhor conforto acústico, higrotérmico e etc, CAVANI (1993).

\subsection{Métodos de avaliação}

Os métodos de avaliação são entendidos como métodos padronizados que permitem verificar se um determinado produto atende aos requisitos e critérios de desempenho para ele fixados, MITIDIERE FILHO \& SOUZA (1994).

Segundo SOUZA (1983), os métodos de avaliação podem ser estabelecidos a partir de ensaios e medidas, cálculos e julgamentos técnicos.

A avaliação através de ensaios e medidas pode ser realizada de dois modos:

a) para determinação de propriedades físicas e químicas dos componentes e elementos do edifício como por exemplo, a determinação da condutibilidade térmica de materiais ou da resistência à compressão do concreto $\mathrm{e}$;

b) para reproduzir as condições de exposição de uma maneira simplificada e padronizada. Podem ser realizados em campo, ou seja, no próprio edifício ou em laboratório, onde protótipos ou amostras do produto são testados. É ressaltada a importância da reprodução dos métodos de ensaio, quando se trata de fins de aprovação do produto.

A avaliação através de cálculos, ocorre quando adota-se um modelo de comportamento, e analiticamente a partir de certas propriedades dos materiais e componentes constituintes, assim como das condições de exposição, estima-se tal comportamento e verifica-se se este satisfaz aos 
requisitos e critérios estabelecidos (cálculo do nível de segurança estrutural do edifício, quando submetido a esforços de vento).

O julgamento técnico é baseado no conhecimento de especialistas com base na experiência de casos e condições similares já conhecidos e consagrados pelo uso através da análise do projeto e inspeções em protótipos dos produtos, em fábricas.

Outra maneira comum de avaliação de desempenho é a propensão de fixar o tradicional como referência e comparando com os demais sistemas construtivos julgá-los satisfatório ou não. Um exemplo disso, são os próprios códigos de obras que descrevem procedimentos e regras a serem obedecidas ao invés de fixar exigências a serem respeitadas. 


\section{AVALIAÇÃO DE DESEMPENHO ESTRUTURAL}

Como o conceito de "estrutura" é o elemento ou conjunto de elementos vinculados entre si, constituindo a parte resistente e de suporte da edificação, ou seja, tem como função suportar cargas externas e internas atuantes na mesma, a segurança estrutural é vista como a exigência de que as construções mantenham certas caracteristicas básicas de comportamento estrutural durante sua utilização.

O elemento estrutural é considerado seguro desde que, IPT (1981):

a) garanta a permanência das características estruturais da construção a custo razoável de manutenção;

b) em condições normais de utilização, não tenha aparência que cause inquietação aos usuários;

c) em situações não previstas de utilização ou de manutenção, apresente sinais visíveis de advertência de eventuais estados perigosos.

O desempenho estrutural, também chamado de nivel de desempenho de uma edificação, deve ser analisado do ponto de vista dos estados limites último e de utilização, ou seja, a estrutura da edificação e suas vedaçöes não deverão ao longo de sua vida útil entrar em ruína, nem apresentarem falhas que venham a prejudicar a durabilidade da construção ou os níveis de satisfação exigidos por seus usuários, SOUZA (1983). Como já dito anteriormente, os critérios e os requisitos de desempenho para avaliação estrutural foram fixados visando garantir que a habitação não atinja estes estados limites. 
Como este trabalho trata da segurança estrutural de sistemas construtivos inovadores, dar-se-á ênfase às exigências, aos requisitos e critérios de desempenho e aos métodos de avaliação referente ao tema proposto.

\subsection{Exigências do usuário}

As exigências dos usuários são definidas como as necessidades que devem ser satisfeitas, pelo edifício, a fim de que este cumpra sua função (IPT 1981).

Segundo MITIDIERI FILHO (1988), as exigências do usuário, no caso do edifício de uso habitacional, correspondem às exigências humanas que devem ser satisfeitas, sejam elas de caráter fisiológico, psicológico, sociológico e econômico.

Dentre as abordagens existentes sobre as exigências dos usuários, destaca-se a lista contida na norma ISO/DP 6241 (International Organization for Standardization / Draft Proposal), são elas:

a) Exigências de segurança estrutural - estabilidade e resistência mecânica;

b) Exigências de segurança ao fogo - limitações do risco de início e propagação de um incêndio, segurança dos usuários;

c) Exigências de segurança à utilização - segurança dos usuários e segurança a intrusões;

d) Exigências de estanqueidade - estanqueidade aos gases, aos líquidos e aos sólidos;

e) Exigências de conforto higrotérmico - temperatura e umidade do ar e das paredes;

f) Exigências atmosféricas - pureza do ar e das paredes;

g) Exigências de conforto visual - pureza do ar e limitações de odores;

h) Exigências de conforto acústico - aclaramento, aspecto dos espaços e das paredes; 
i) Exigências de conforto tátil - eletricidade estática, rugosidade, umidade, temperatura da superfície;

j) Exigências de conforto antropodinâmico - acelerações, vibrações e esforços de manobras;

k) Exigências de higiene - cuidados corporais, abastecimento de água, eliminação de matérias usadas;

1) Exigências de adaptação à utilização - número, dimensões, geometria e relações de espaços e de equipamentos necessários;

m)Exigências de durabilidade - conservação do desempenho ao longo do tempo;

n) Exigências de economia - custo inicial e custos de manutenção e reposição durante $\mathrm{o}$ uso.

É evidente, que há exigências de caráter essencial que devem ser totalmente satisfeitas, como a segurança estrutural, e outras, de caráter relativo, que podem ser estabelecidas através da relação satisfação/custo, como o conforto e durabilidade.

Para MITIDIERI FILHO (1988), o conceito de exigência do usuário é bastante relativo, varia de país para país ou mesmo para cada região dentro de um mesmo país pois, o que constitui exigência para um país desenvolvido pode constituir-se apenas em desejo para aqueles menos desenvolvidos.

\subsection{Condições de exposição}

As condiçōes de exposição são definidas como um conjunto de açōes atuantes sobre um determinado produto durante sua vida útil (IPT 1981). A norma ISO/DP 6241 (International Organization for Standardization / Draft Proposal), apresenta uma listagem dos principais agentes que atuam na edificação.

As açöes podem ocorrer devido a fenômenos de origem natural (ventos, chuvas, etc.), de origem externa ao edifício (impactos externos) e 
devidas ao próprio uso do edifício (sobrecargas de utilização, focos de incêndio, etc.). Para cada uma das exigências do usuário associa-se um conjunto de condições de exposição que devem ser consideradas.

Para um determinado sistema inovador satisfazer as exigências dos usuários, quanto à segurança estrutural, deve-se conhecer sua resistência à determinadas ações (condições de exposição), tais como forças devidas à ação de vento, cargas impostas pela estrutura e demais elementos, impactos de corpo mole, impactos de corpo duro e impactos de portas.

$\mathrm{Na}$ parte prática deste trabalho, foram realizados nos sistemas construtivos, empregados na Vila Tecnológica, os ensaios de impacto de corpo mole, impacto de corpo duro, cargas provenientes de peças suspensas e fechamento brusco de portas. Não foram realizados o ensaio de cargas impostas pela estrutura (ensaio de compressão de paredes), visto que, as unidades já estavam concluídas estando portanto com suas devidas cargas atuantes, e também, o ensaio de ação de vento, devido a difícil viabilização de sua execução, tratando-se de ensaios realizados em campo. Sendo assim, a descrição dos requisitos e critérios de desempenho, como também, dos métodos de avaliação utilizados, estão relacionados com os ensaios realizados no estudo de caso.

\subsection{Requisitos de desempenho estrutural}

Segundo o relatório "Avaliação de Desempenho de Habitações Térreas Unifamiliares", apresentado pelo IPT (Instituto de Pesquisas Tecnológicas) relaciona-se a seguir, os requisitos referentes aos ensaios realizados no estudo de caso em questão.

\subsubsection{Requisitos de desempenho estrutural para ação de impactos de corpo mole}

Sob ação de impactos de corpo mole decorrentes da utilização normal da edificação, as paredes externas e internas devem apresentar resistência satisfatória e suas deformações devem manter-se dentro dos limites aceitáveis. 


\subsubsection{Requisitos de desempenho estrutural para ação de impactos de corpo duro}

Sob a ação de impactos de corpo duro decorrentes da utilização normal da edificação, as paredes externas e internas não devem apresentar ruptura ou avarias graves que prejudiquem sua função ou aspecto.

\subsubsection{Requisitos de desempenho estrutural para ação de cargas provenientes de peças suspensas}

As paredes externas e divisórias internas devem apresentar resistência mecânica aos esforços produzidos por cargas provenientes de peças suspensas como armários, prateleiras, etc e suas deformações devem manter-se dentro dos limites aceitáveis compatíveis com as condições de utilização previstas.

\subsubsection{Requisitos de desempenho estrutural para solicitações transmitidas por fechamento brusco de portas}

As paredes não devem apresentar avarias graves nem rupturas quando submetidas a solicitações transmitidas por portas externas.

\subsection{Critérios de desempenho estrutural}

Os critérios de desempenho, relacionados a seguir, referem-se às paredes externas das edificações, objeto da avaliação da segurança realizada na Vila Tecnológica de Ribeirão Preto.

\subsubsection{Critério de desempenho estrutural para ação de impactos de corpo mole}

As paredes externas com função portante quando submetidas a impactos de corpo mole, com energias de 120J, 240J (3 impactos), 360J, $480 \mathrm{~J}, 720 \mathrm{~J}$ e $960 \mathrm{~J}$, devem atender às seguintes exigências: sob ação do primeiro impacto com energia de 240J a deformação horizontal não deve ser maior que $\mathrm{h} / 250$ e a deformação horizontal residual, medida no terceiro 
impacto de $240 \mathrm{~J}$, não deve ser maior que $\mathrm{h} / 1250$ onde $\mathrm{h}$ é a altura da parede; sob ação dos impactos com energia de $120 \mathrm{~J}, 240 \mathrm{~J}$, 360 J e $480 \mathrm{~J}$ não devem ocorrer danos e nos impactos de $720 \mathrm{~J}$ e $960 \mathrm{~J}$ a não ocorrência de ruína.

\subsubsection{Critério de desempenho estrutural para ação de impactos de corpo duro}

Aplica-se às paredes externas, com ou sem função estrutural, que quando sujeitas a impactos de corpo duro de pequenas dimensões aplicados em qualquer ponto, não devem ocorrer fissuras, estilhaçamentos ou mossas superiores a $2,0 \mathrm{~mm}$. Para impactos de corpo duro de grandes dimensões, também aplicados em qualquer ponto da parede, não deve, ocorrer ruptura ou transpassamento.

\subsubsection{Critério de desempenho estrutural para ação de cargas provenientes de peças suspensas}

Aplica-se às paredes, com ou sem função estrutural, que provavelmente receberão cargas provenientes de armários, lavatórios, prateleiras, etc. Estas paredes devem resistir a um carregamento de $1 \mathrm{kN}$ ou 1,5 vezes a carga a ser transmitida pela peça suspensa, aplicado em dois pontos, distantes $30 \mathrm{~cm}$ da parede. Não devem ocorrer: deformações horizontais maiores que $\mathrm{h} / 500$, deformações horizontais residuais maiores que $\mathrm{h} / 2500$ ( $\mathrm{h}=$ altura da parede) e rupturas, fissuras ou arrancamento dos dispositivos de fixação.

\subsubsection{Critério de desempenho estrutural para solicitações transmitidas por fechamento brusco de portas}

Sob ação de dez fechamentos bruscos de portas externas, as paredes externas com função estrutural, não devem apresentar danos de qualquer natureza, tais como rupturas, fissurações, destacamentos no contorno do marco, bem como na regiäo de fixação do mesmo, destacamento nas juntas entre painéis e avarias nas guarnições do batente. 


\subsection{Métodos de avaliação estrutural}

Os ensaios realizados na aplicação prática deste trabalho são descritos a seguir:

\subsubsection{Ensaio para verificação do comportamento sob ação de impactos de corpo mole de grande dimensão}

Procura reproduzir impactos de corpo mole decorrentes de choques acidentais provocados pelo próprio uso da edificaçăo ou choques provocados por intrusões intencionais ou não.
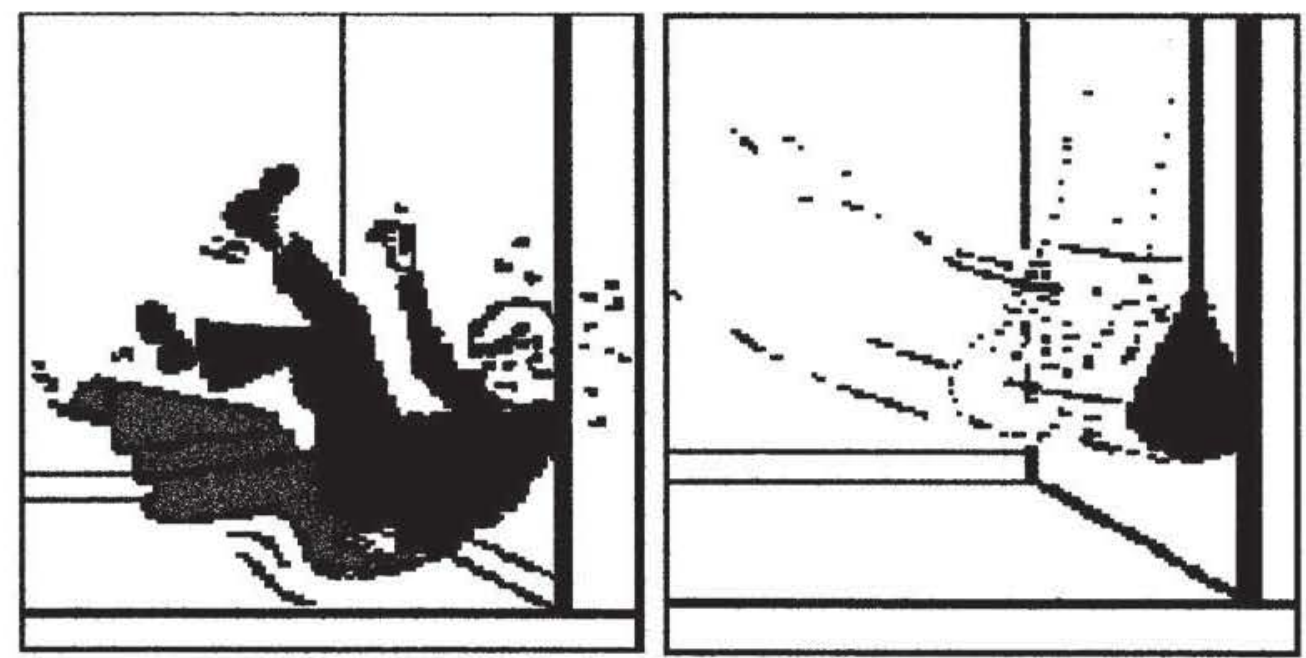

Figura 06 - Representação do ensaio de impactos de corpo mole de grande dimensão - extraída de MITIDIERI FILHO,C.V (1988).

O ensaio verifica a resistência das paredes quando submetidas a impactos externos. A aparelhagem utilizada no ensaio é baseada na norma MB - 3256 "Divisórias Leves Internas Moduladas - Verificação da Resistência a Impactos" e consiste de sistema pendular constituído de um suporte para sustentação de um saco cilíndrico de couro com diâmetro de $350 \mathrm{~mm}$ e altura de $900 \mathrm{~mm}$ contendo areia seca e serragem com massa total de $40 \mathrm{~kg}$, e um paquímetro de resolução $0,1 \mathrm{~mm}$ colocado no centro de gravidade da parede oposta a ser ensaiada, para medir as deformações horizontais instantâneas e residuais. 
O ensaio consiste em suspender o saco cilíndrico de modo que na posição de repouso tangencie o corpo de prova. Para a produção dos impactos, afasta-se o saco de couro até que seu centro de gravidade atinja as alturas $(\Delta \mathrm{h})$ de $30,60,90,120,180$ e $240 \mathrm{~cm}$ a partir da posição de repouso, atingindo o corpo de prova com energias de 120, 240 (3 impactos), $360,480,720$ e $960 \mathrm{~J}$ respectivamente. Após cada impacto é realizada a leitura no paquímetro e a parede é inspecionada visualmente. Depois de 15 minutos é feita a leitura da deformação residual.

O esquema do ensaio pode ser visto na figura 07.

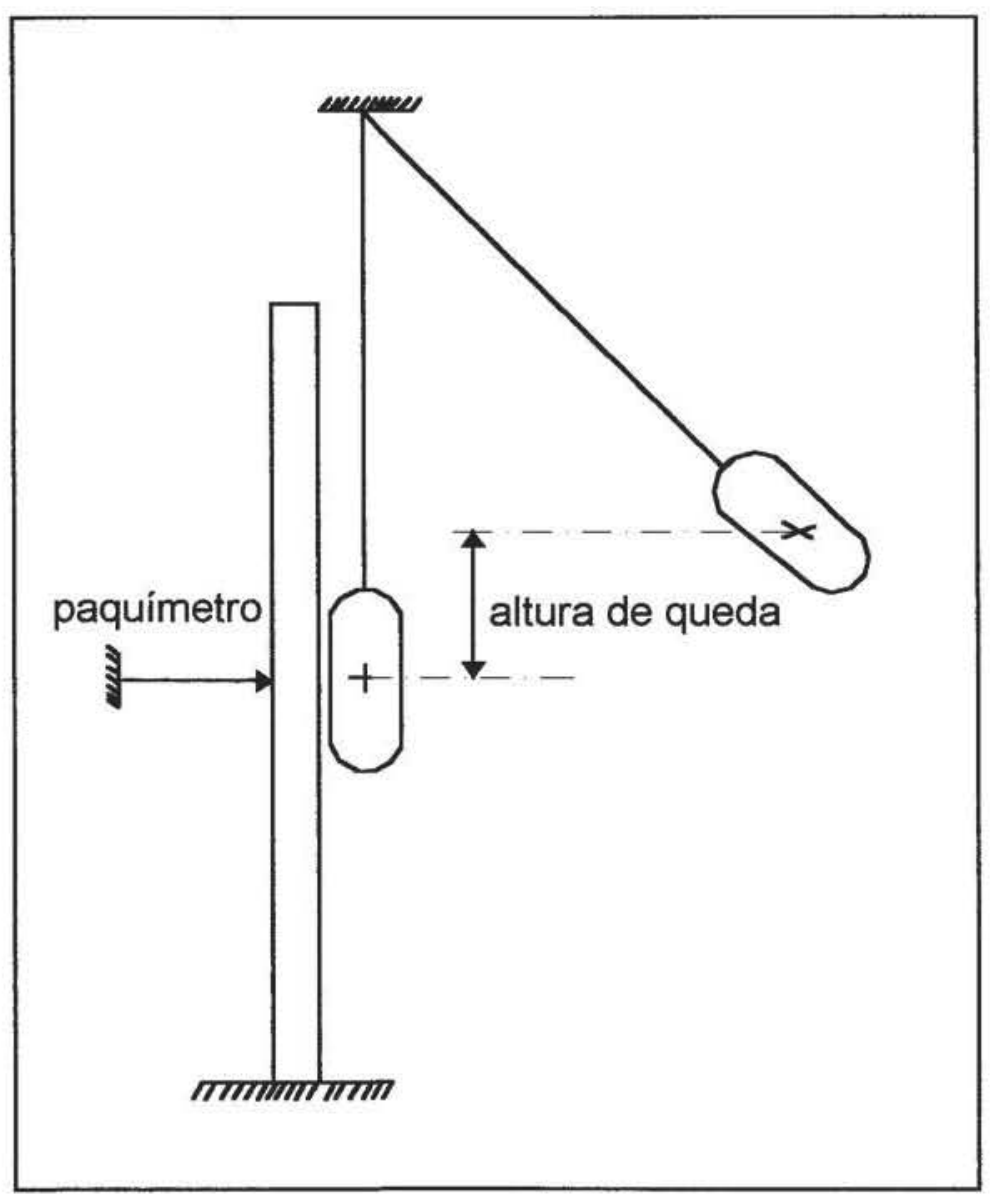

Figura 07 - Esquema do ensaio de impactos de corpo mole de grande dimensão. 


\subsubsection{Ensaio para verificaçăo do comportamento sob açăo de impactos} de corpo duro de pequena e grande dimensăo.

Procura reproduzir impactos gerados dentro da edificação decorrente ao seu uso ou externamente à edificação através de corpos duros.
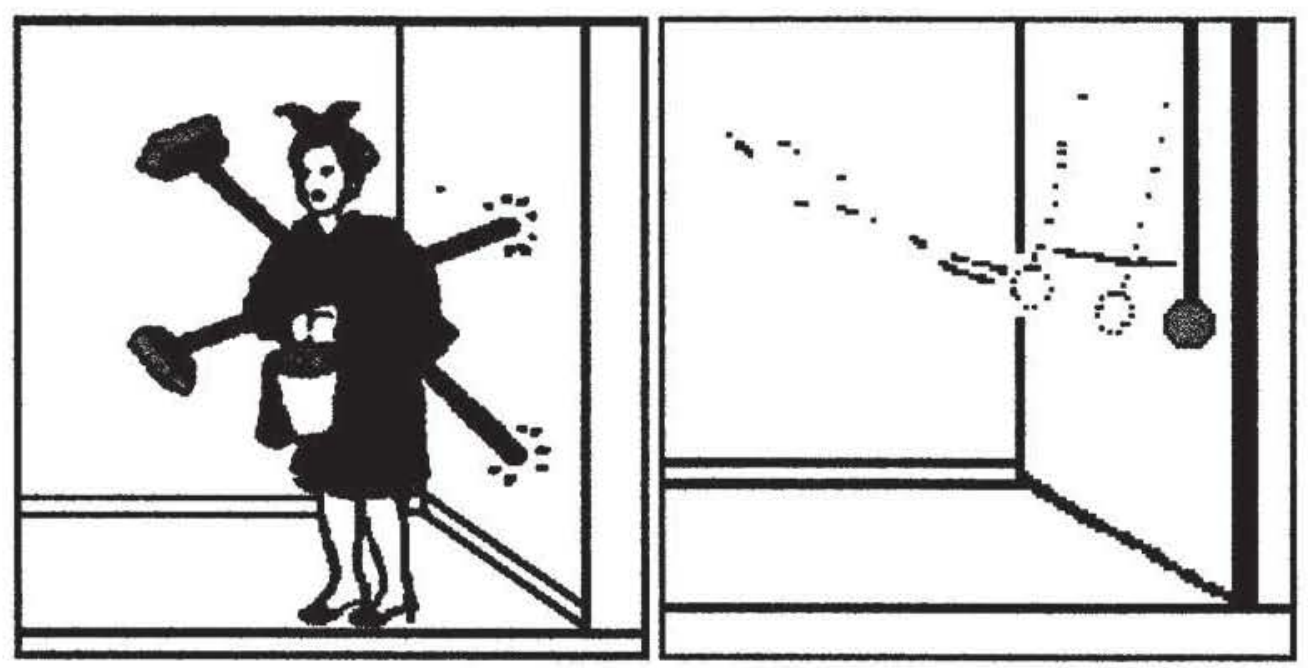

Figura 08 - Representação do ensaio de impactos de corpo duro extraida de MITIDIERI FILHO,C.V (1988).

$O$ ensaio verifica o comportamento de paredes quando submetidas a impactos de pequenas e grandes dimensöes. A aparelhagem utilizada no ensaio é baseada na norma MB - 3256 "Divisórias Leves Internas Moduladas - Verificação da Resistência a Impactos" e é composta de sistema pendular constituído de um suporte para sustentação de esferas de aço de pequenas $(m=0,5 \mathrm{~kg})$ e grandes $(m=1,0 \mathrm{~kg})$ dimensões, e um paquímetro de profundidade de resolução de $0.1 \mathrm{~mm}$ para medir as mossas provocadas pelos impactos.

O ensaio consiste em suspender a esfera de aço (corpo duro) por meio do fio de aço, de modo que, na posição de repouso, tangencie a superfície do corpo de prova no ponto de aplicação do impacto. Para produção dos impactos, a esfera de aço deve ser afastada do corpo de prova até seu centro de gravidade atingir as alturas de $0,75 \mathrm{~m}$ (esfera de $0,5 \mathrm{~kg}$ ) e 2,0m (esfera de 1,0kg). As esferas são então abandonadas 
individualmente em movimento pendular, atingindo o corpo de prova em pontos aleatórios, com energias de $3,75 \mathrm{~J}$ (10 impactos) e $20 \mathrm{~J}$ (10 impactos). Após cada impacto o corpo de prova é analisado visualmente e a profundidade das mossas medidas pelo paquímetro.

0 esquema do ensaio pode ser visto na figura 09.

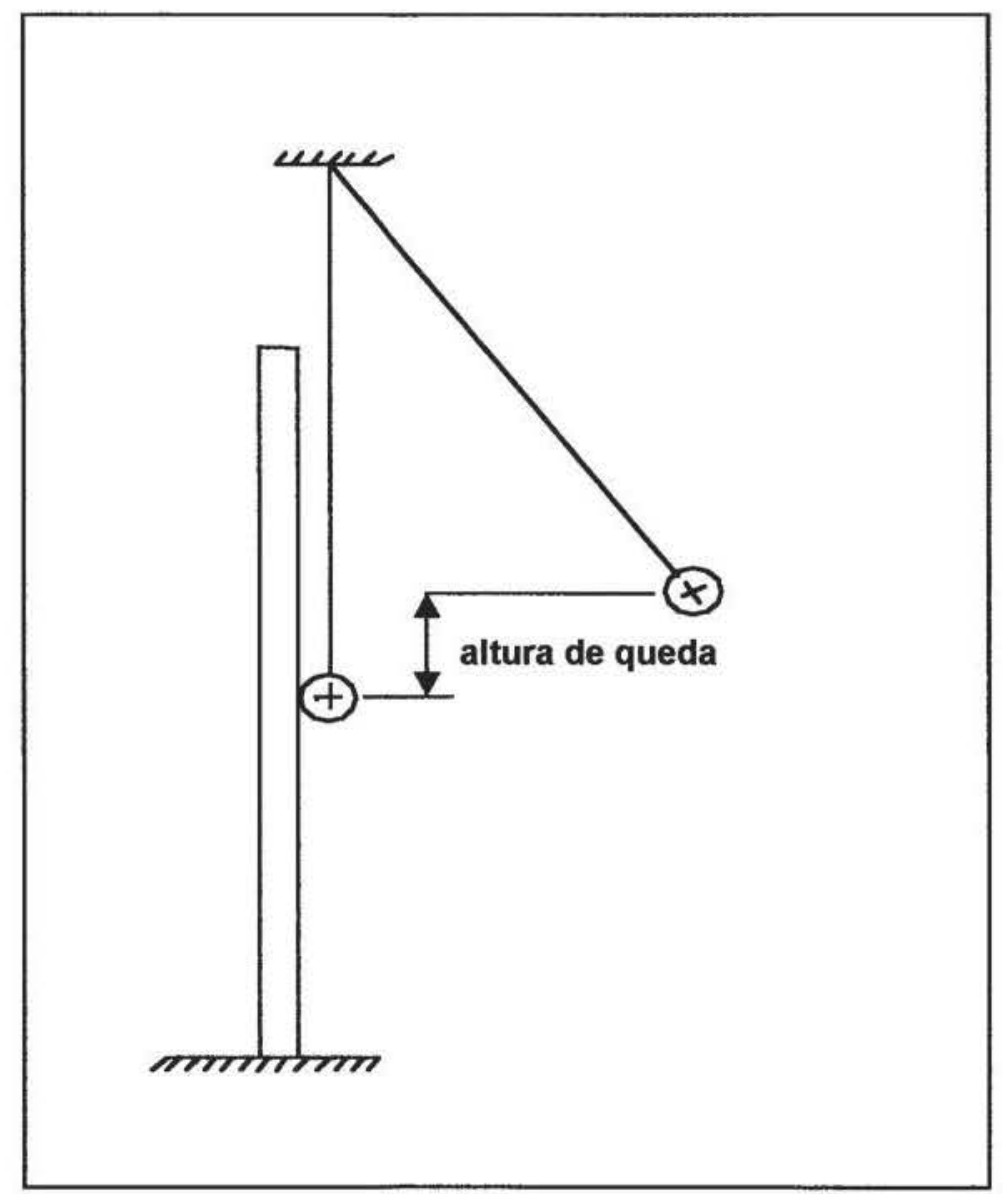

Figura 09 - Esquema do ensaio de impactos de corpo duro 


\subsubsection{Ensaio para verificaçăo do comportamento sob açăo de cargas provenientes de peças suspensas}

Procura reproduzir, dentre outros, cargas provenientes de armários, prateleiras e pias suspensas.
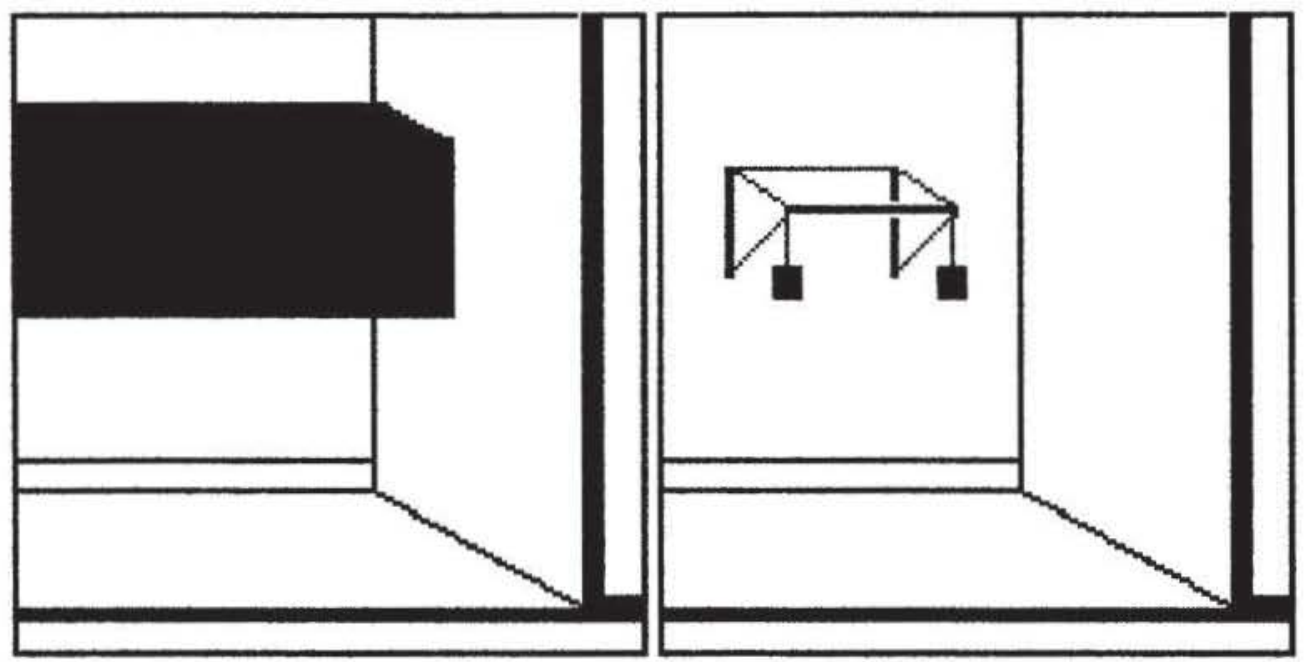

Figura 10 - Representação do ensaio de cargas provenientes de peças suspensas

Este ensaio é aplicável em paredes externas e internas e verifica seu comportamento quando submetidas às solicitaçőes transmitidas por cargas provenientes de peças suspensas, como lavatórios, armários, prateleiras etc. A aparelhagem é baseada na norma MB - 3259 "Divisórias Leves Moduladas - Verificação do Comportamento sob Ação de Cargas Provenientes de Peças Suspensas".

Após a fixação das mãos francesas e dos relógios comparadores situados no lado oposto da parede a ser ensaiada, o ensaio é iniciado aplicando a carga (contra pesos) gradativamente até atingir $1 \mathrm{kN}$. A carga permanece aplicada durante 24 horas, quando são registradas as deformaçöes horizontais. Após a retirada do carregamento aguarda-se $15 \mathrm{~min}$ para o registro da deformaçăo horizontal residual.

O esquema do ensaio pode ser visto na figura 11. 


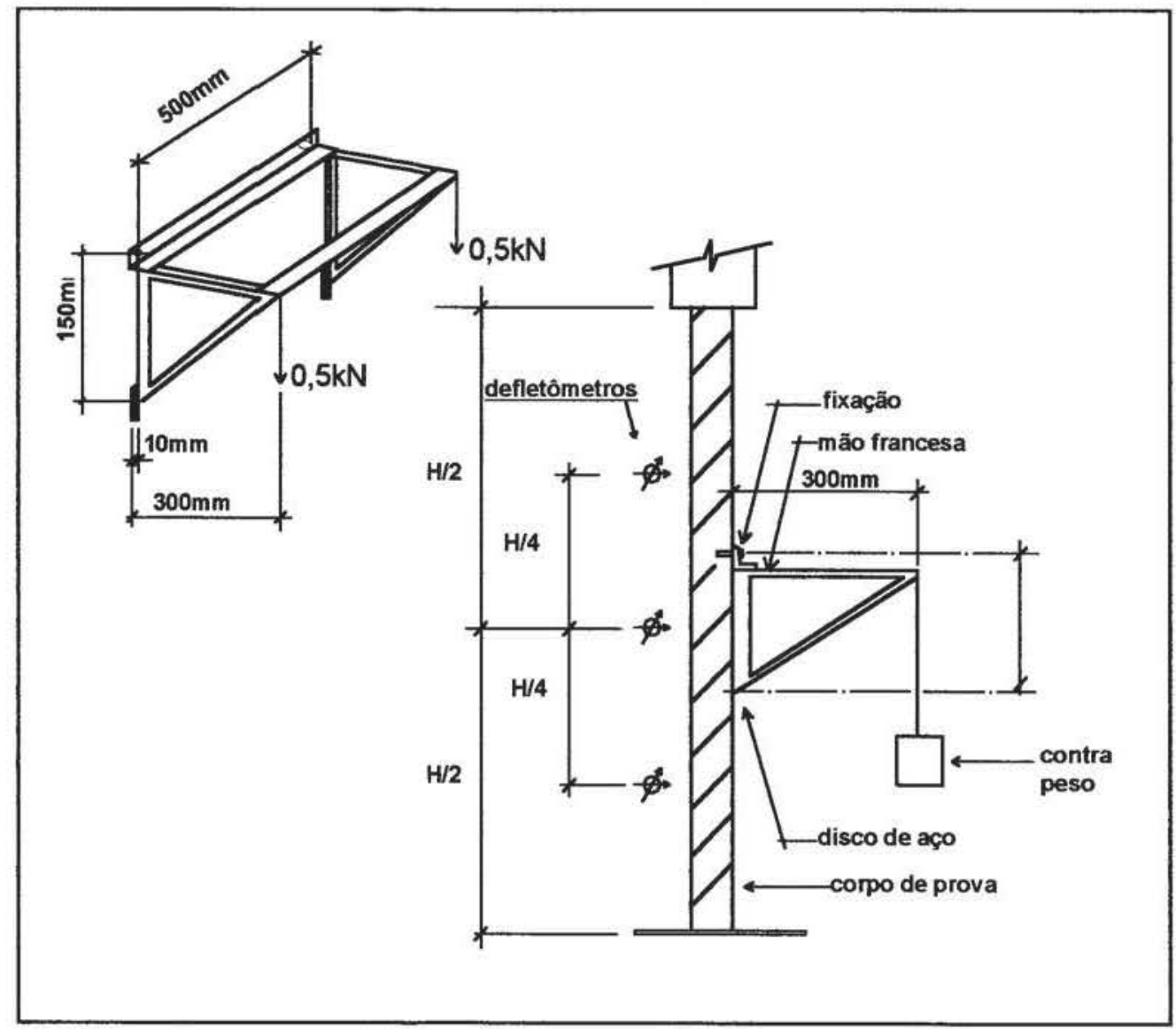

Figura11 - Esquema do ensaio de cargas provenientes de peças suspensas 


\subsubsection{Ensaio para verificaçăo do comportamento sob açăo de} fechamentos bruscos de portas

Procura reproduzir fechamentos bruscos de portas causados por manobras anormais como por exemplo, o vento.
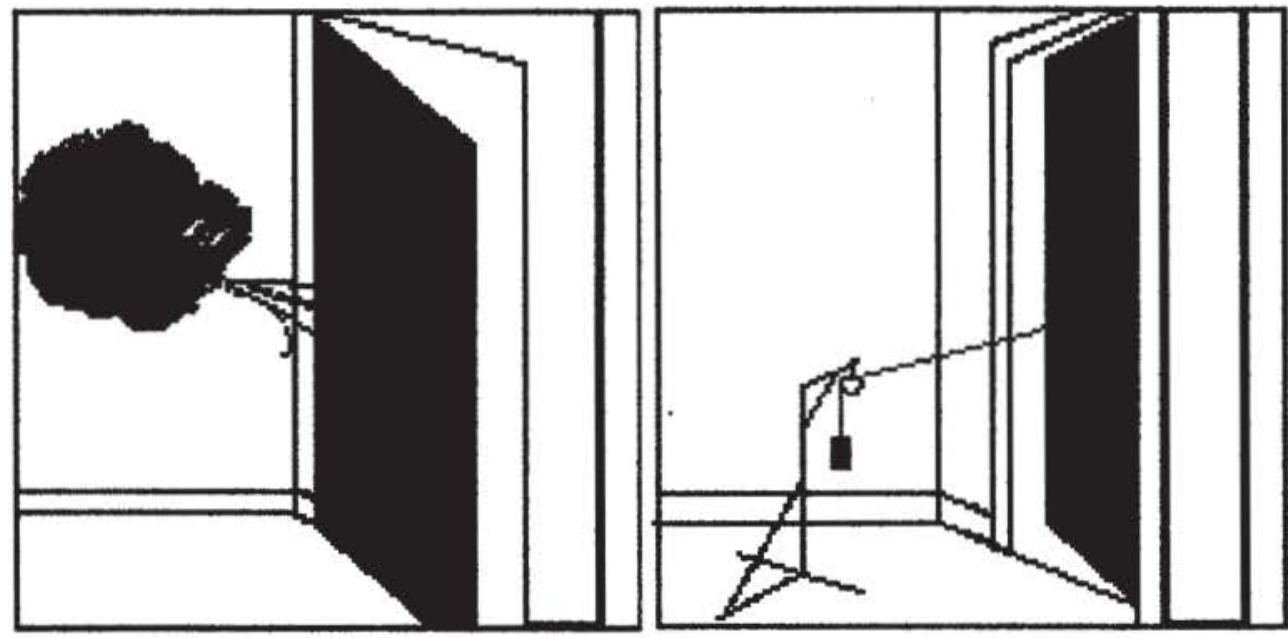

Figura 12 - Representação do ensaio de fechamento brusco de portas.

Este ensaio verifica o comportamento de paredes externas devido a interação com portas quando estas são submetidas a fechamento brusco. A aparelhagem do ensaio é baseada na norma NBR 8054 "Porta de Madeira de Edificação - Verificação do Comportamento da Folha Submetida a Manobras Anormais".

O procedimento do ensaio consiste em manter a folha da porta aberta formando um ângulo de $60^{\circ} \mathrm{com}$ o plano do batente e com o auxílio de um sistema constituído por um fio de aço, roldana, suporte de roldana e contrapeso, aplicar à maçaneta da porta uma força de $150 \mathrm{~N}$ perpendicular ao plano da porta de modo que, antes da porta atingir o marco, a força produzida năo esteja mais atuando. São aplicados 10 fechamentos bruscos evitando repiques. Após cada um deles são registradas as ocorrências observadas tanto no contorno do marco quanto na porta ensaiada.

O esquema do ensaio pode ser visto na figura 13. 


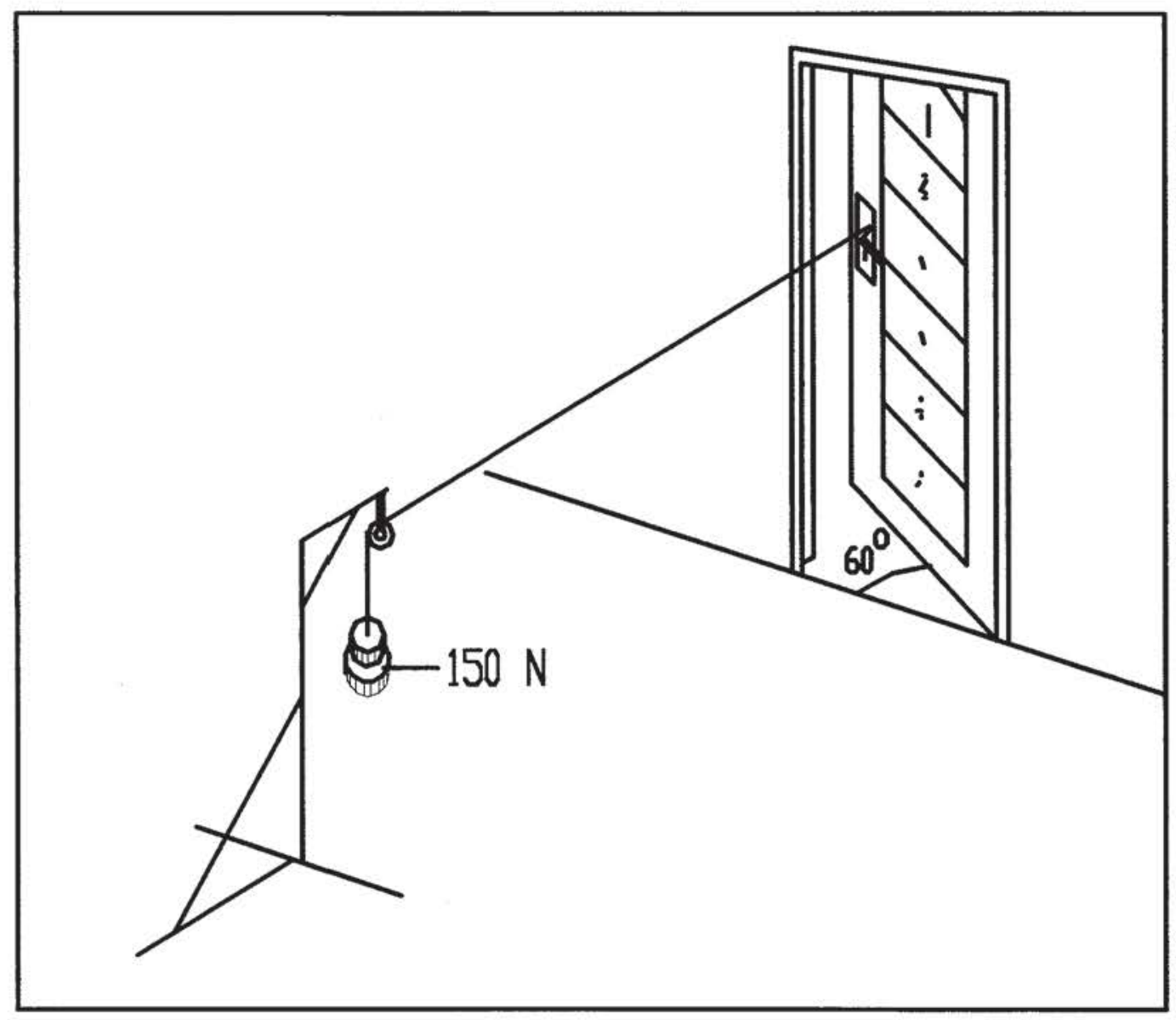

Figura 13 - Esquema do ensaio de fechamento brusco de portas. 


\section{ESTUDO DE CASO}

O PROTECH - Programa de Difusão de Tecnologia para Construção de Habitação de Baixo Custo - projeto criado no âmbito da Secretaria Geral da Presidência da República implantou no ano de 1993, em Curitiba - PR a primeira Vila Tecnológica do país. Na mesma época iniciou projetos para execução, de Vilas Tecnológicas, em Ribeirão Preto - SP, Juiz de Fora MG, Brasília - DF, Cuiabá - MT, Contagem - MG e Bauru - SP.

O programa institucionaliza um novo conceito de "habitat" considerando a habitação no sentido amplo, levando em consideração aspectos ligados às atividades econômicas, a tecnologia, às questões espaciais, ambientais e culturais e às aspirações populacionais.

Com isso, redireciona as soluções para o déficit habitacional até hoje tentadas, incentivando a produção de moradias com métodos construtivos inovadores para habitação popular, segundo uma visão realista dos problemas econômicos, sociais, históricos, políticos e culturais. 0 cumprimento destes aspectos, demonstra a boa qualidade da habitação. Qualquer desvio, por desconsideração parcial de um dos aspectos considerados, traduz-se em desarmonia nas relações e, portanto, na menor qualidade habitacional.

Sendo assim, o programa incentiva as inovações tecnológicas, para alcançar soluções que diminuam os custos de produção, sem afetar a qualidade da habitação, ou seja, construir um número maior de habitações com uma qualidade igual ou melhor ao do modelo tradicional, empregando melhor os recursos e conseqüentemente barateando a construção.

Como na metodologia básica para o desenvolvimento de um sistema construtivo a avaliação de desempenho é levada em consideração, os 
programas que surgem tentando resolver o déficit habitacional no pais, devem estar acompanhados de uma avaliação, inclusive pós ocupação para comprovar se as inovações satisfazem as aspirações e exigências dos usuários.

Em julho de 1994, o PROTECH juntamente com a COHAB - RP (Companhia de Habitação Regional de Ribeirão Preto) implantaram em Ribeirão Preto a Vila Tecnológica com 111 habitações e a Rua das Tecnologias com 20 unidades construídas com 11 das mais variadas tecnologias.

Com o objetivo de acompanhar desde o processo licitatório, até a execução das diversas tecnologias propostas, foi criado através de um Decreto Municipal, o Conselho Consultivo da Vila Tecnológica, composto por representantes do governo, da população, das universidades, entidades representativas de categorias profissionais e empresários.

Dentre as atribuições do Conselho Consultivo pode-se ressaltar a avaliação, dos sistemas construtivos alternativos, com relação à segurança estrutural, 'a avaliação relativa ao ambiente construído e à pós-ocupação que ficaram a cargo dos representantes das universidades, coordenadas pela escola de Engenharia de São Carlos, da Universidade de São Paulo.

Sendo assim, os sistemas construtivos alternativos, empregados na construção da Vila Tecnológica de Ribeirão Preto, foram avaliados visando sua qualificação junto ao PROTECH, para futuros empreendimentos. Durante a avaliação, as habitações construídas com uma das tecnologias, se encontravam em fase de execução, o que impossibilitou a realização dos ensaios. Portanto, dos onze sistemas construtivos alternativos, dez foram avaliados estruturalmente. Foi então, uma rara oportunidade dispor-se de tão vasto campo de provas para o desenvolvimento da pesquisa proposta, com a coleta e análise dos resultados obtidos durante a avaliação. 


\subsection{Avaliação de desempenho: metodologia aplicada}

A avaliação quanto à segurança estrutural realizada na Vila Tecnológica-RP teve o objetivo de verificar o comportamento estrutural dos sistemas construtivos nela empregados baseando-se nos critérios e requisitos adotados pelo IPT, bem como nas normas da ABNT.

Os ensaios (já descritos no item 4.5) foram realizados em campo, em um protótipo escolhido aleatoriamente representando cada tecnologia empregada. A importância deste método de avaliação é destacada, pois trata-se da aprovação de produtos, e também, por representarem o verdadeiro comportamento de uma habitação quando solicitada por determinadas ações, já que, as unidades estavam concluídas.

Imaginou-se inicialmente que os critérios adotados para verificar o desempenho de sistemas construtivos alternativos pudessem estar muito rigorosos, visto que, a maioria das construções eram habitações leves. Considerou-se então, como referência padrão, um modelo convencional de construção aceito pelos usuários, para que seus valores fossem considerados como um padrão mínimo de qualidade.

A avaliação foi então realizada, submetendo-se cada sistema construtivo a ensaios e, para comparação e controle dos resultados, uma habitação convencional, "padrão COHAB" (casa de alvenaria de blocos vazados cerâmicos), foi submetida aos mesmos ensaios, servindo como valores de referência.

Nos ensaios realizados na casa "padrão $C O H A B$ ", os resultados obtidos foram inferiores ao máximo admissivel pelos critérios de desempenho, e em geral, mais satisfatórios que os sistemas construtivos avaliados, sendo assim, tomou-se estes valores, como referência de qualidade satisfatória para avaliação dos sistemas inovadores.

De posse destes limites - os critérios de desempenho e os valores da casa padrão, a avaliação foi feita adotando-se 3 niveis de qualidade: satisfatório, regular e insatisfatório. Considerou-se satisfatórios os sistemas que possuem seus resultados menores ou iguais ao padrão 
$\mathrm{COHAB}$ (valores $\leq \mathrm{COHAB}$ ) logo, são sistemas com qualidade de tecnologia superior ao do método convencional.

Os sistemas cujos valores estiverem entre o padrão COHAB e o máximo admitido pelo critério (COHAB < valores $\leq$ CRITÉRIO) foram considerados regulares. Estes sistemas, apesar de apresentarem comportamento inferior ao padrão de referência são considerados satisfatórios pelos critérios de desempenho adotados. Propõe-se que os sistemas que estiverem neste nivel, sofram uma melhoria de qualidade para que seu desempenho seja pelo menos igual ao da casa padrão.

Já os sistemas que obtiverem seus valores maiores que o limite máximo admissivel foram considerados insatisfatórios. Sugere-se então, a estes sistemas uma rigorosa revisão em todo seu processo de fabricação, ou seja, da produção à execução, e ainda, se necessário a substituição de materiais por outros com melhor desempenho.

Para evitar a comparação pura e simples de resultados, o que não teria sentido na avaliação pretendida, buscou-se uma relação que eliminasse as variáveis de cada sistema de construção (altura, espessura, material), visto que, a maioria dos critérios adotados estavam relacionados com as paredes dos protótipos e suas deformaçōes horizontais, instantâneas e residuais. Sendo assim confrontou-se inicialmente, os resultados obtidos nos ensaios com os máximos admitidos pelos critérios de avaliação.

1 - (deformacão máx. permitida pelo critério - deformacão observada) deformação máxima permitida pelo critério

Esta relação expressa quanto do valor da deformação encontrada é equivalente ao máximo permitido. Como exemplo de interpretação da expressão acima, pode-se dizer que, caso o resultado seja 0,7 ou $70 \%$, o valor da deformação é equivalente a $70 \%$ do máximo permitido, ou ainda, se 
o resultado for $130 \%$, significa que a deformação ultrapassou $30 \%$ o máximo permitido.

Vale ressaltar que a avaliação proposta não se prende apenas a uma análise quantitativa de resultados mas, inclui também a análise qualitativa que permitiu definir limites para classificação dos sistemas alternativos além do que, muitos dos critério de desempenho envolvem ocorrências qualitativas como, aparecimento de fissuras, ruína, diminuição de rigidez, etc.

Os sistemas construtivos avaliados, incluindo a habitação padrão COHAB, estão relacionados a seguir, em função da tecnologia adotada na execução das paredes.

Habitação convencional "padrão COHAB" - casa de alvenaria de tijolo cerâmico com 6 furos revestido.

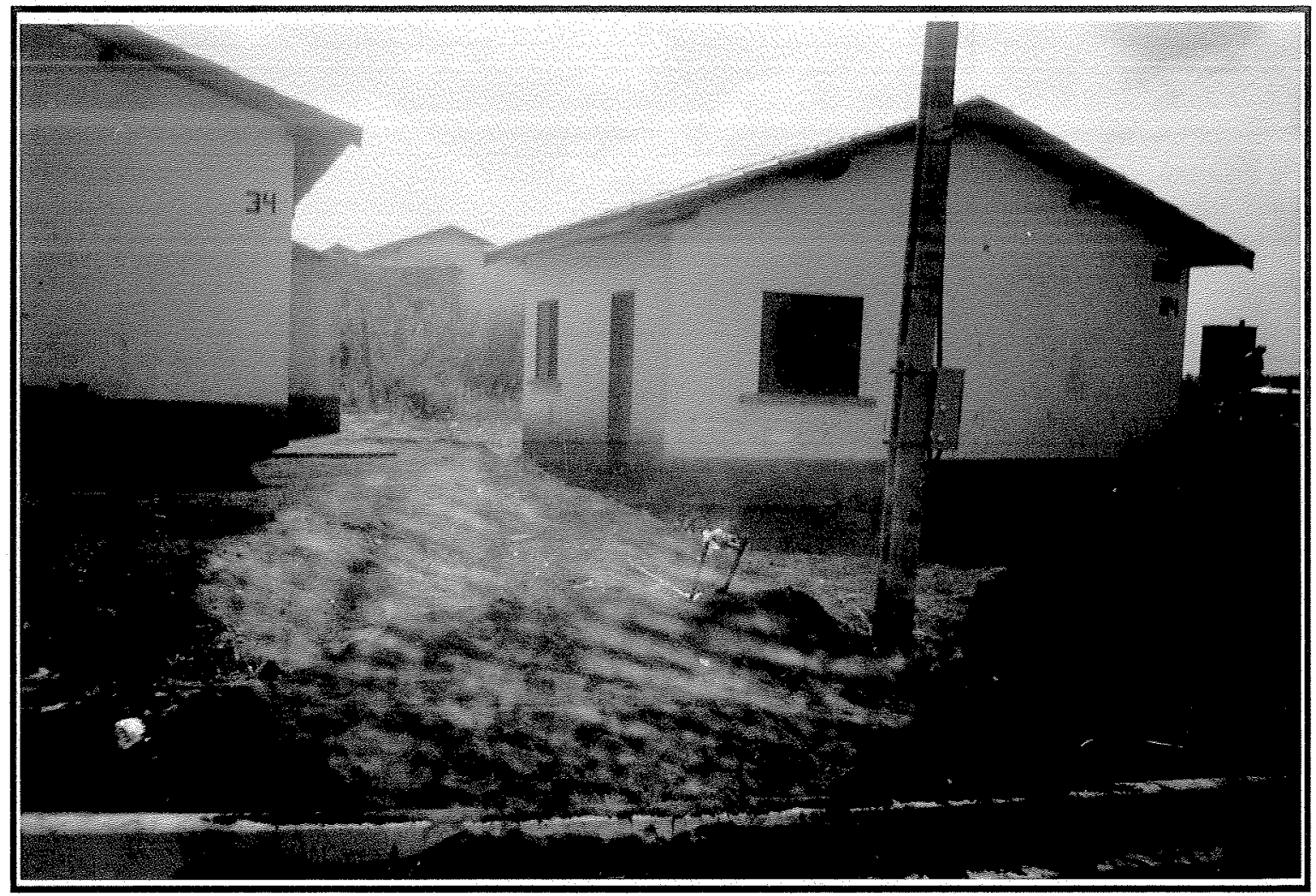


Sistema construtivo $B$ - painéis estruturais pré - fabricados em concreto.

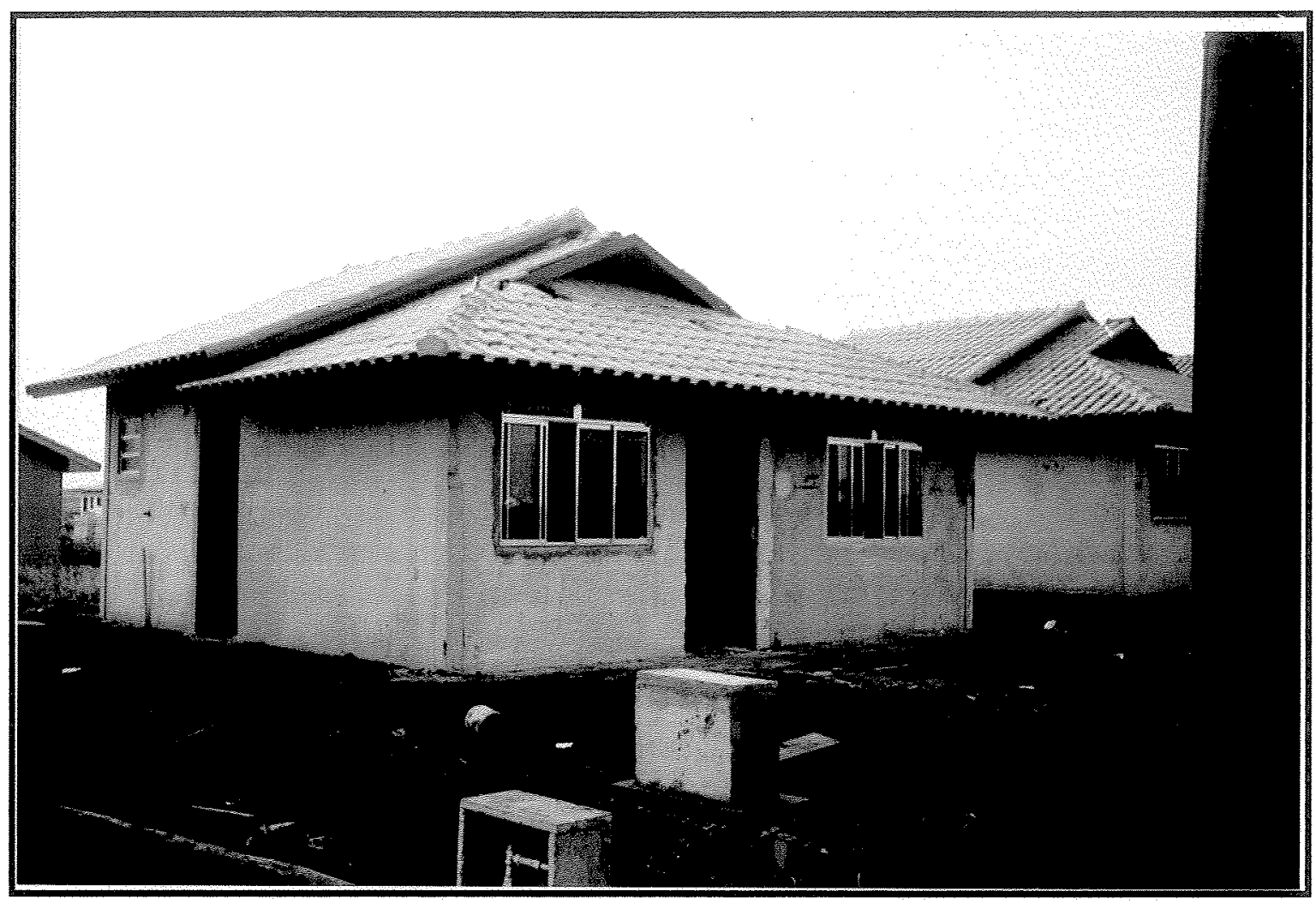

Sistema construtivo C - painéis autoportantes, tipo "sandwich", estrutura interna de madeira tratada e recoberta por chapa tipo "Hard Board", revestida com argamassa epóxica.

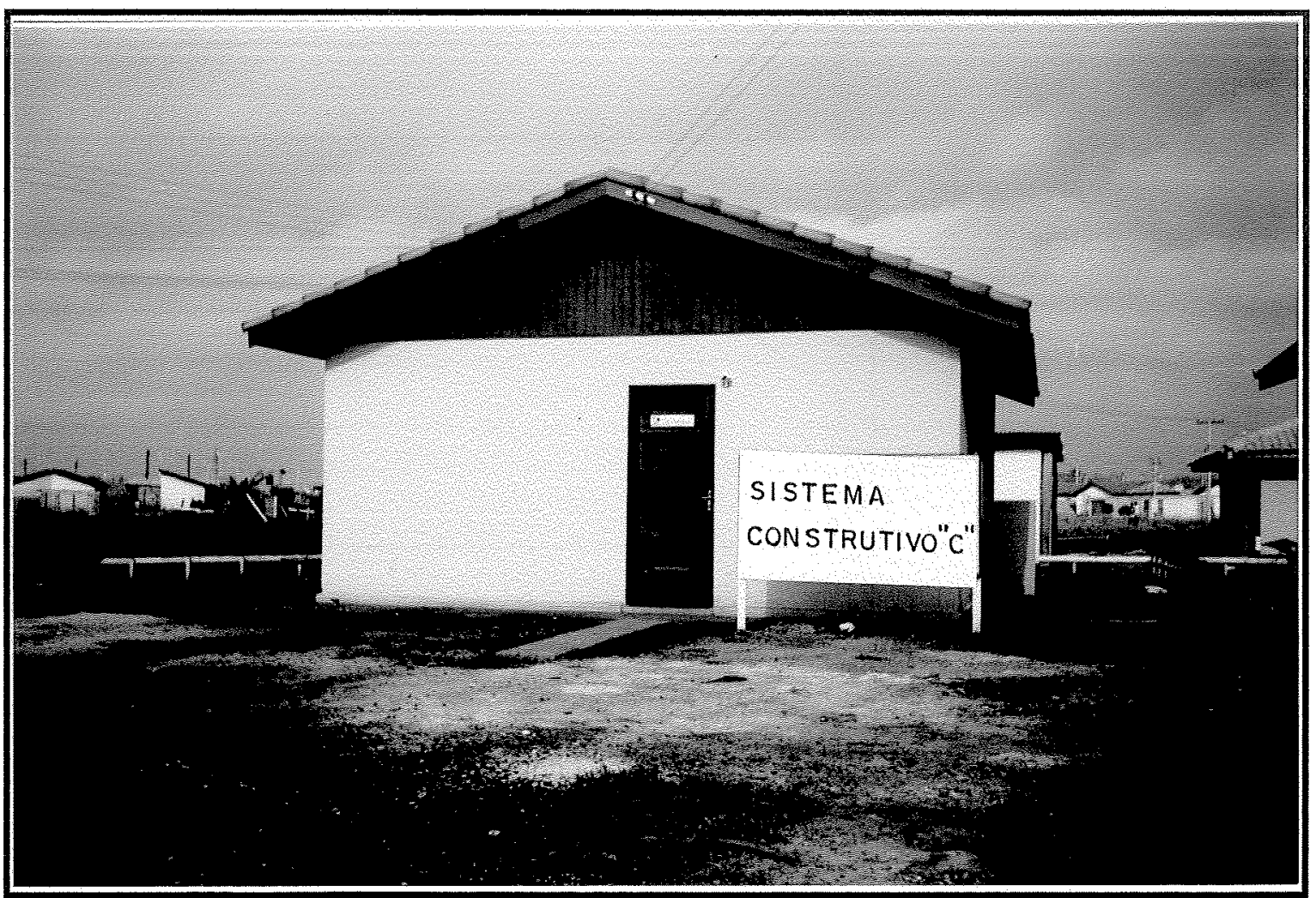


Sistema construtivo D - alvenaria de tijolos de solo-cimento vazados intertravados.

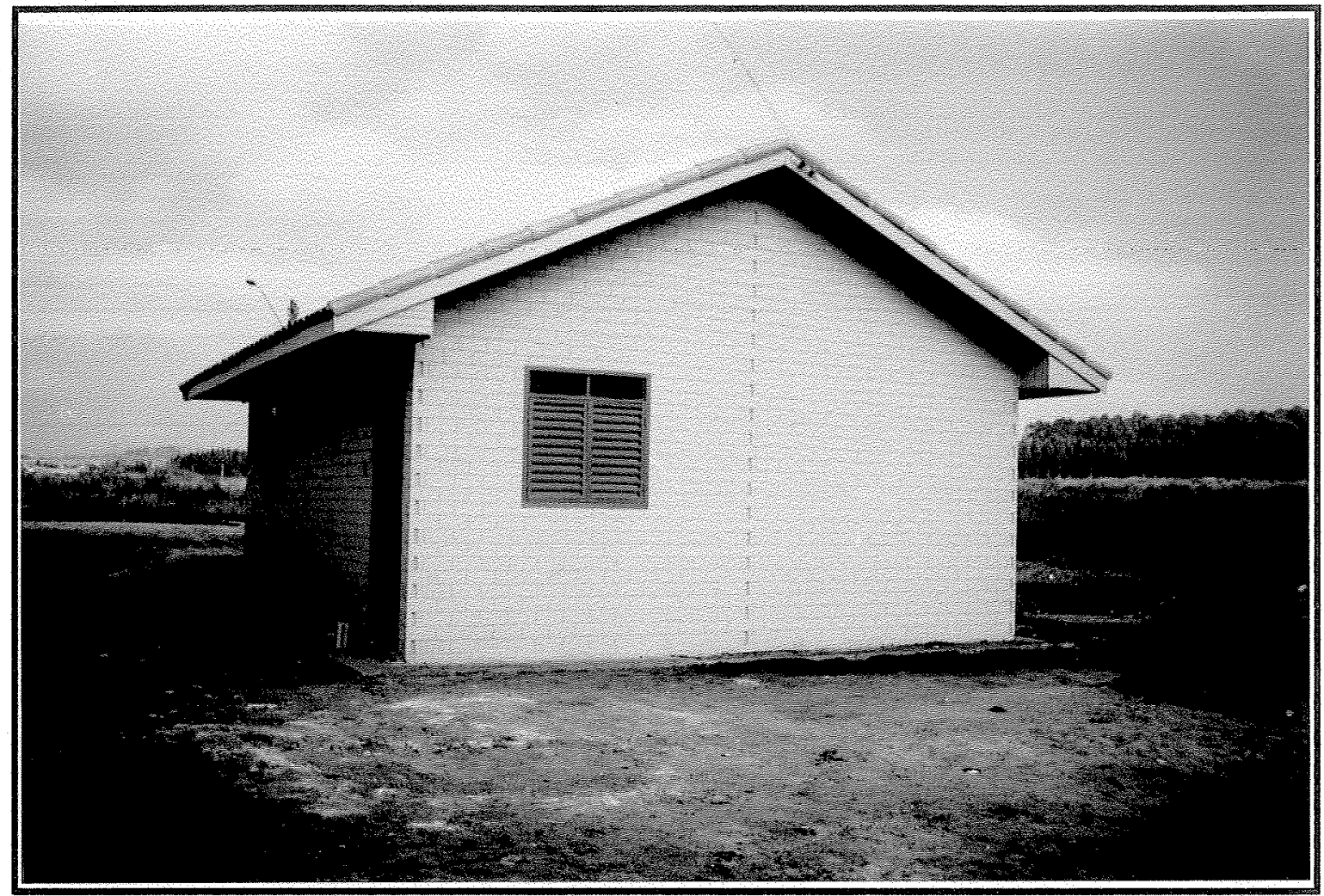

Sistema construtivo $\mathbf{E}$ - painéis pré-fabricados em concreto armado com núcleo de bloco cerâmico.

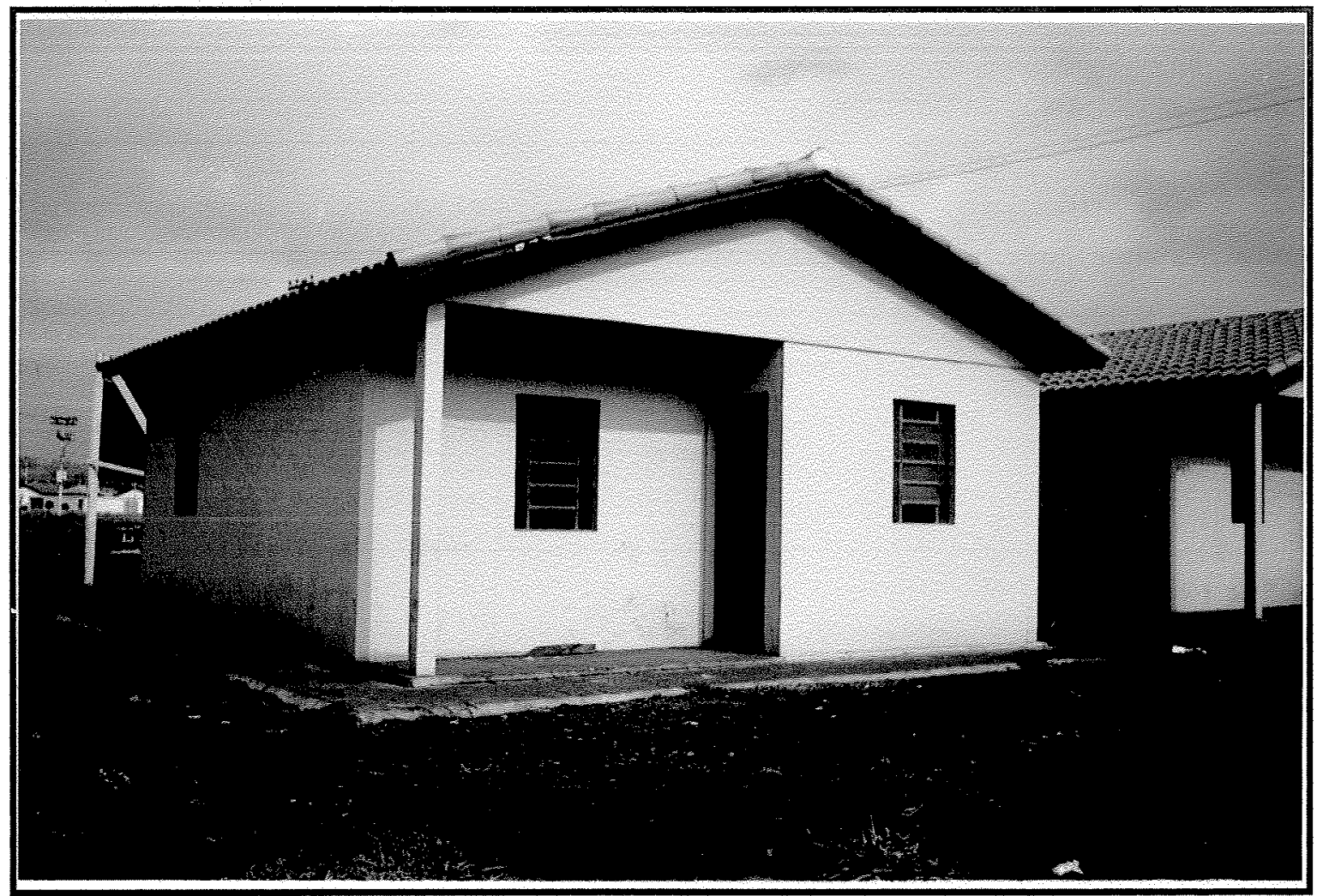


Sistema construtivo $F$ - blocos cerâmicos, com encaixe macho/fêmea, permitindo a superposição e o intertravamento, dispensando o uso da argamassa.

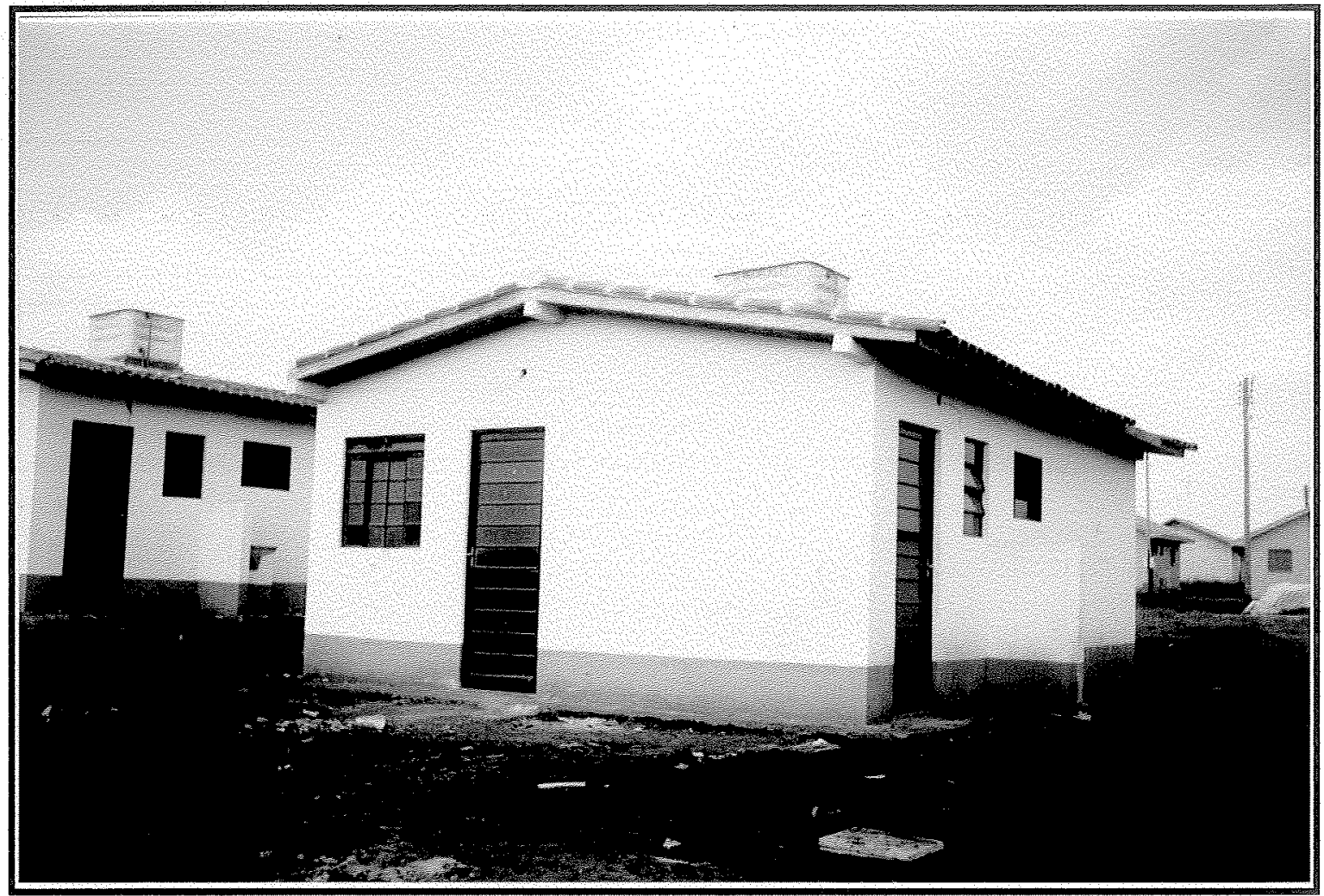

Sistema construtivo $\mathbf{G}$ - painéis pré - fabricados de poliestireno expandido e tela de aço, revestidos com argamassa, jateada com fibras de polipropileno.

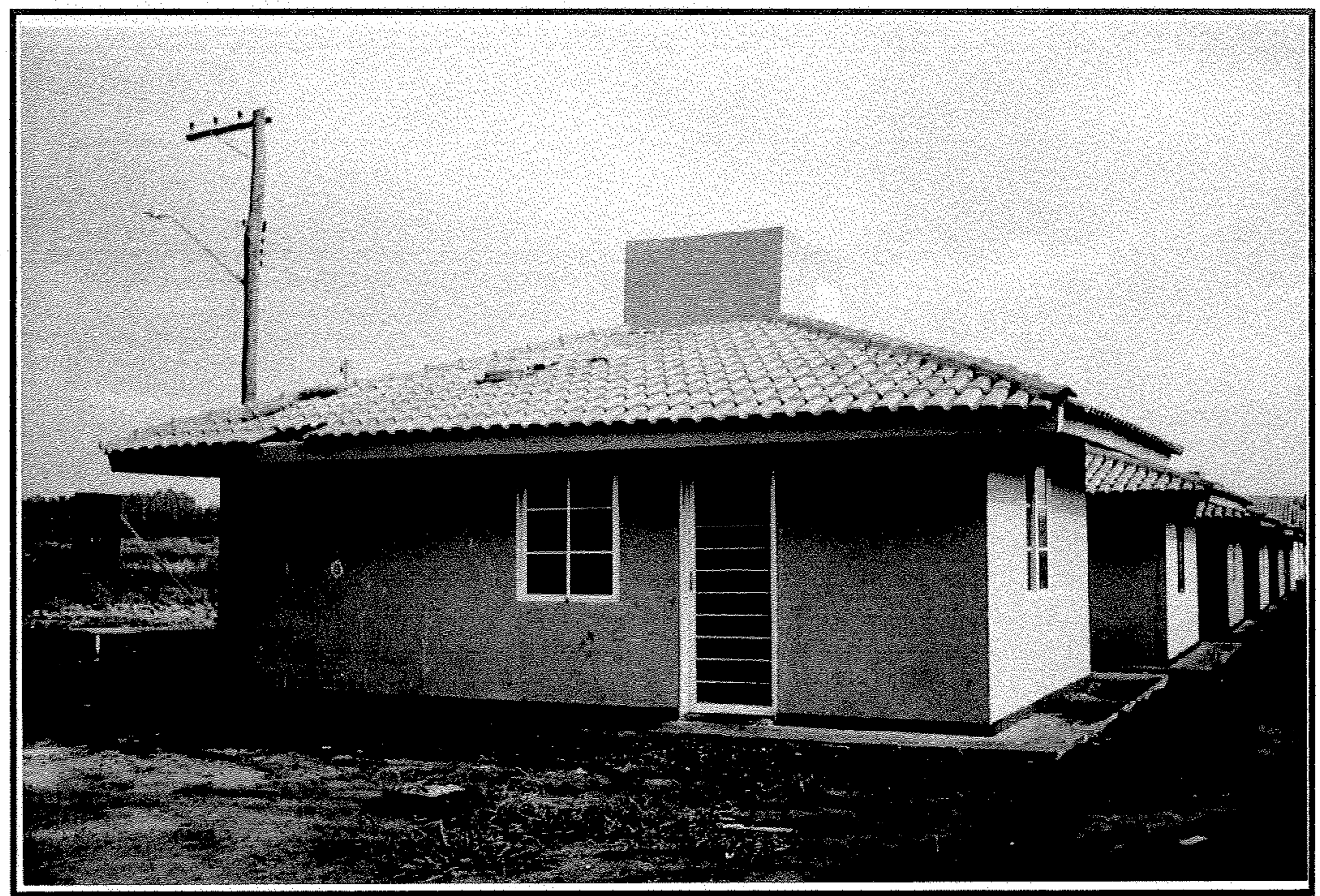


Sistema construtivo $\mathrm{H}$ - painéis em madeira de lei industrializada.

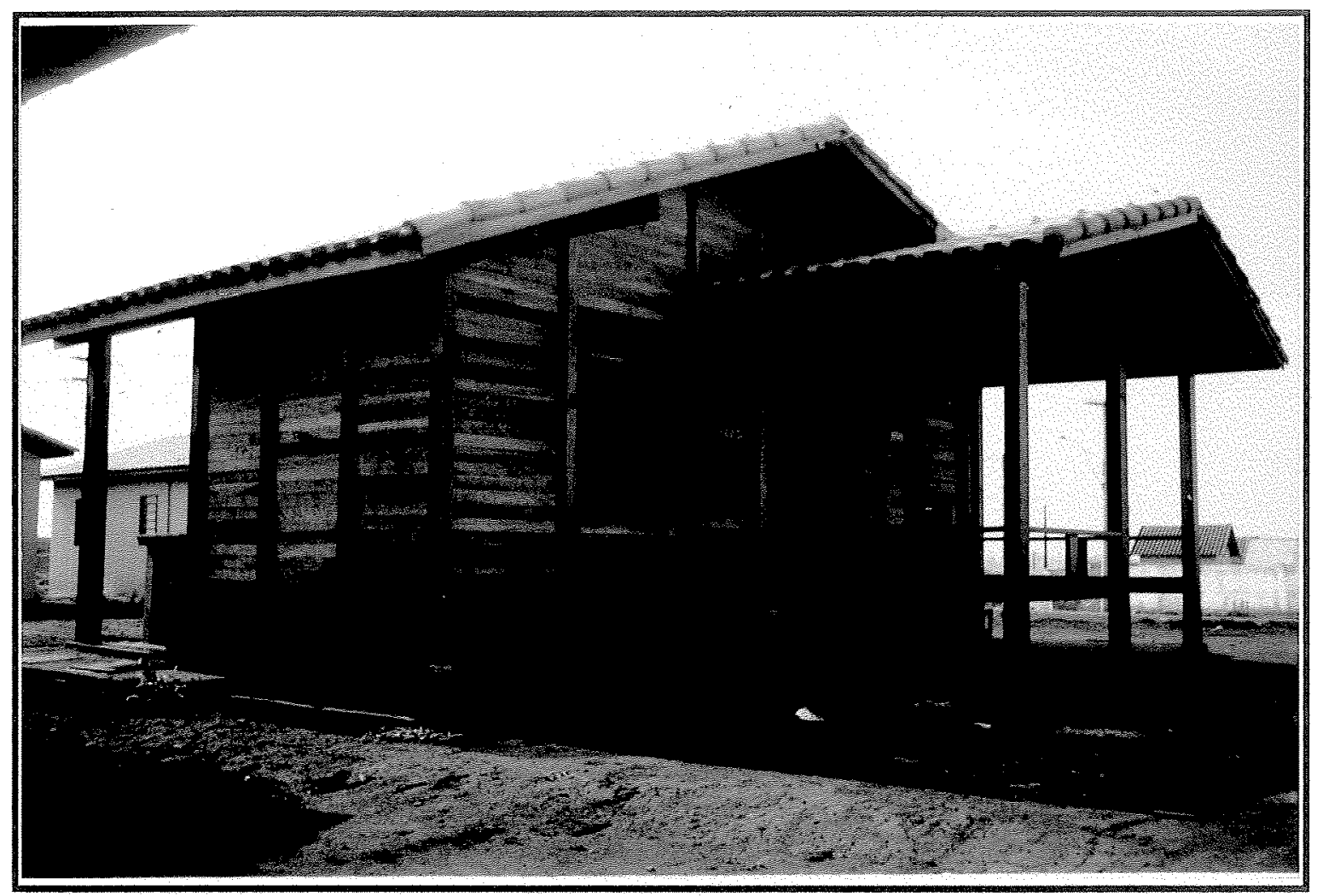

Sistema construtivo I - painéis pré - fabricados tipo "sandwich" de concreto e núcleo de poliestireno.

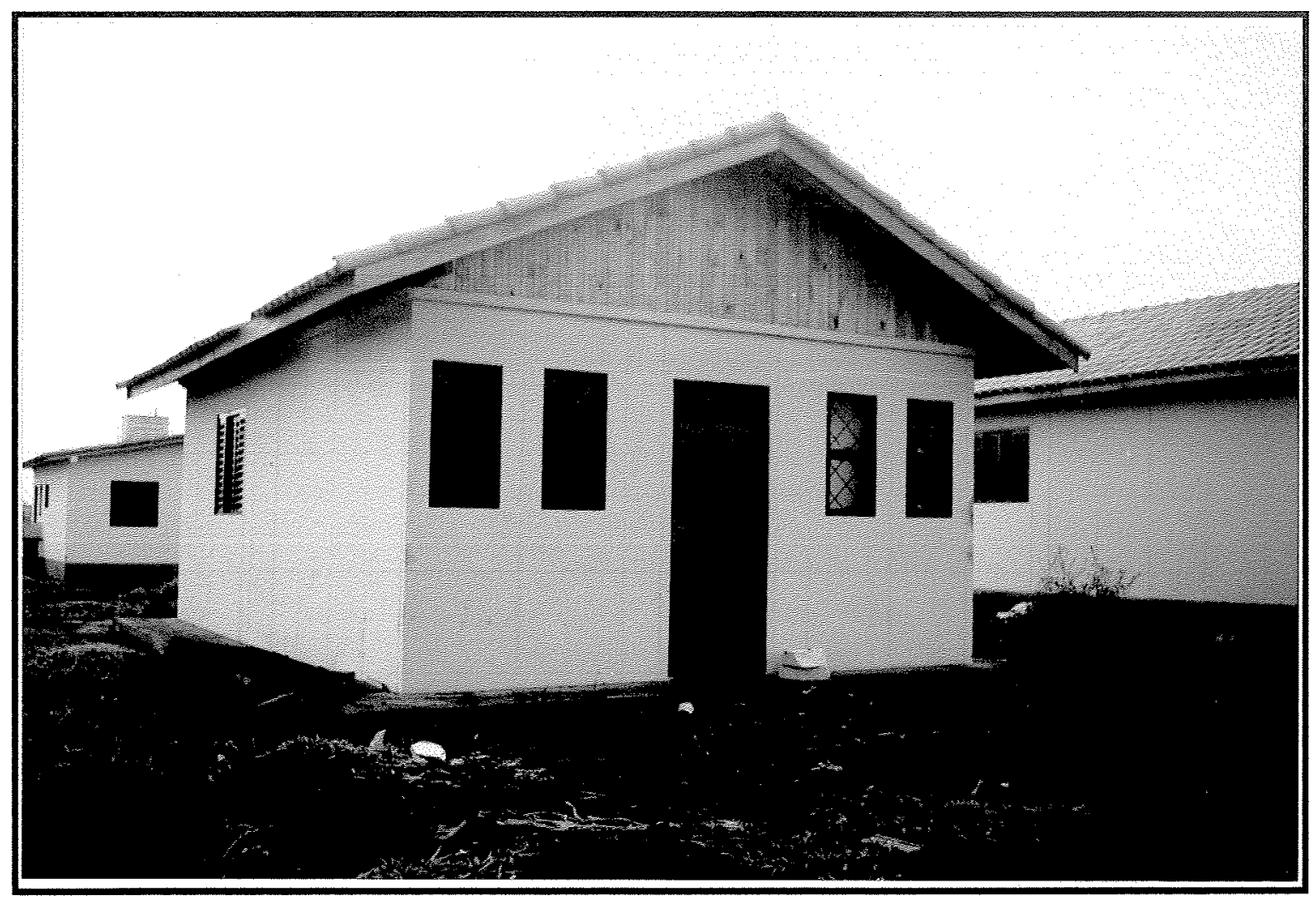


Sistema construtivo $\mathfrak{J}$ - blocos de concreto com sistema de auto encaixe e auto travamento, executado com massa especial.

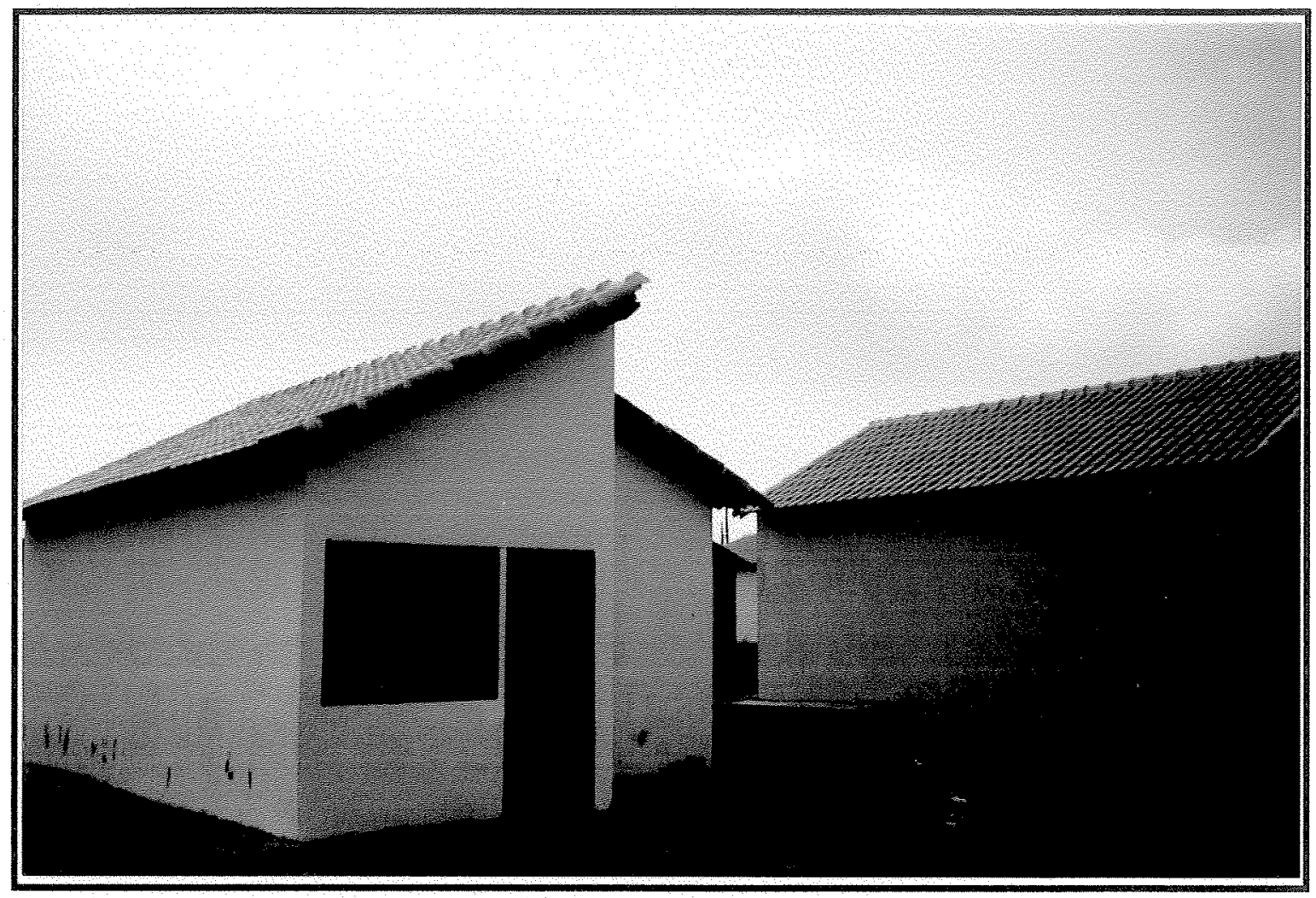

Sistema construtivo $\mathbf{K}$ - colunas pré - moldadas espaçadas com placas pré fabricadas em concreto, lisas ou imitando tijolo à vista.

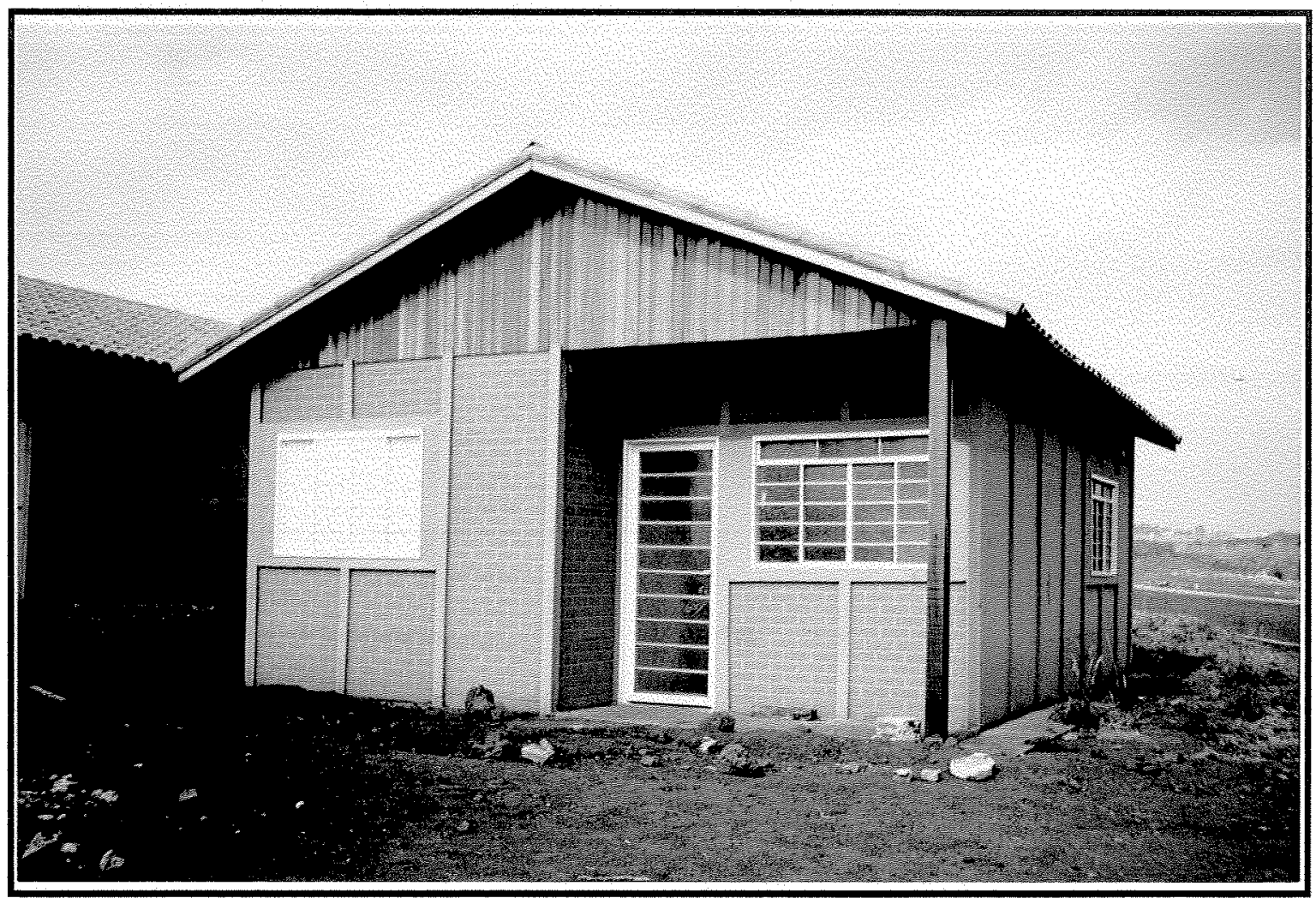




\subsection{Análise dos resultados}

Os resultados registrados, dos ensaios realizados em campo, foram inicialmente analisados individualmente para uma prévia avaliação quanto ao desempenho dos sistema construtivo. Após a análise referente a cada ensaio são apresentadas tabelas onde os resultados estão resumidamente descritos, juntamente com a limitações pertinentes ao critério de desempenho. $\dot{E}$ apresentada também, após a tabela, a documentação fotográfica referente ao ensaio.

\subsubsection{Ensaio para verificaça do comportamento sob ação de impactos de corpo mole de grande dimensão}

Os resultados de interesse ao ensaio referem-se às paredes externas submetidas à impactos de corpo mole de grande dimensão onde não devem ocorrer danos ou ruínas. As deformações referentes ao $1^{\circ}$ e $3^{\circ}$ impacto de $240 \mathrm{~J}$ devem manter-se dentro dos limites aceitáveis, h/250 e h/1250 respetivamente.

a) Sistema construtivo convencional - "tpadrão COHAB"

O protótipo ensaiado atende às exigências do critério de desempenho, no que se refere à parede analisada, ou seja:

Os impactos com 120,240,360, e 480J, não provocaram danos de qualquer natureza no elemento ensaiado. Os impactos com 720 e $960 \mathrm{~J}$ não provocaram a ruina de parte ou do elemento como um todo.

As deformações, instantânea e residual, medidas no primeiro e terceiro impacto respectivamente, com energia de $240 \mathrm{~J}$ foram bastante inferiores aos máximos permitidos.

b) Sistema construtivo $\mathbf{B}$

Não houve registro de ocorrências em todo o transcorrer do ensaio, portanto estão atendidas as exigências que se referem a não ocorrência de 
danos nos impactos de 120, 240 e 360J, e a não ocorrência de ruína nos impactos de 720 e $960 \mathrm{~J}$.

As deformações anotadas, no primeiro e terceiro impacto de 240J, são inferiores aos limites máximos admitidos no critério de desempenho.

c) Sistema construtivo C

As ocorrências anotadas durante a execução do ensaio, foram de pequena monta o que atende as exigências dos critérios estabelecidos. A deformação instantânea, registrada no primeiro impacto com energia de 240J, ultrrapassou o limite máximo admitido. Já a deformação residual, anotada no terceiro impacto, é bem inferior ao máximo admitido. Isto se deve ao comportamento elástico do painel (grandes deslocamentos sem deformações residuais consideráveis).

d) Sistema construtivo D

As ocorrências registradas no transcorrer do ensaio, foram de pequena magnitude e atendem, portanto, aos critérios de desempenho. As deformações, instantânea e residual, no primeiro e terceiro impacto com energia de $240 \mathrm{~J}$, respectivamente, atendem aos limites máximos admissiveis.

e) Sistema construtivo $\mathbf{E}$

Os resultados do ensaio atendem plenamente às exigências do critério de desempenho. Como poderá ser visto, mais adiante, não foram registradas deformações ou ocorrências durante o transcorrer do ensaio

\section{f) Sistema construtivo $F$}

As duas primeiras exigências do critério foram atendidas, pois não houve registro de ocorrências durante a aplicação dos impactos. As deformações anotadas, de interesse, para o confronto com os limites máximos, ficaram bem abaixo dos admitidos pelo critério. 
g) Sistema construtivo $G$

Os impactos produzidos, não provocaram danos de qualquer natureza em todo o transcorrer do ensaio, satisfazendo o critério plenamente, quanto à estes itens. A deformação horizontal, instantânea, anotada (dh=3,00mm) para o primeiro impacto com $240 \mathrm{~J}$, é bem menor que a máxima permitida de $11,50 \mathrm{~mm}$. A deformação residual registrada no terceiro impacto com $240 \mathrm{~J}$ é inferior ao limite máximo de $2,30 \mathrm{~mm}$ estabelecido pelo critério.

h) Sistema construtivo $\mathrm{H}$

O painel componente da parede ensaiada não atende a maioria dos critérios de desempenho. Após o impacto com energia de 480J, registrou-se o rompimento da coluna de sustentação do painel. Após os impactos de 720 e 960J, constatou-se a configuração do estado de ruína do elemento ensaiado. A deformação instantânea medida com o primeiro impacto de 240J, foi quase o triplo do máximo admissível. Após o terceiro impacto de $240 \mathrm{~J}$, não se constatou deformação residual.

\section{i) Sistema construtivo I}

As deformações transversais registradas durante o ensaio, satisfazem os requisitos necessários. Não houve ocorrência de danos significativos, nem configuração do estado de ruína do painel avaliado.

\section{j) Sistema construtivo J}

As inspeções visuais, efetuadas após a aplicação de cada impacto, não mostraram quaisquer ocorrências. As deformações medidas, tanto a instantânea quanto a residual, após o primeiro e o terceiro impacto com $240 J$, respectivamente, foram bem inferiores às limitações impostas pelo critério de desempenho. 
k) Sistema construtivo $\mathbb{K}$

Após aplicação do impacto com energia de 480J, foi constatado fissuras e deformações residuais. Com o impacto de $720 \mathrm{~J}$, configurou-se o estado de ruína do painel ensaiado.

Na tabela 01 pode-se observar os resultados obtidos referente a análise do ensaio em questão, bem como as ocorrências de cada sistema construtivo. 
Tabela 01 - Resumo dos resultados referentes ao ensaio de impactos de corpo mole de grande dimensão

\begin{tabular}{|c|c|c|c|c|c|c|c|}
\hline \multirow{3}{*}{$\begin{array}{c}\text { Sistemas } \\
\text { Construtivos }\end{array}$} & \multirow{3}{*}{$\begin{array}{l}\text { altura parede } \\
\qquad h(m)\end{array}$} & \multirow{3}{*}{$\begin{array}{c}\text { dhmáx. (mm) } \\
240(\mathrm{~J})-1^{\circ} \\
\mathrm{h} / 250\end{array}$} & \multirow{3}{*}{$\begin{array}{c}\text { dhrmáx. (mm) } \\
240(\mathrm{~J})-3^{\circ} \\
\mathrm{h} / 1250\end{array}$} & \multicolumn{4}{|c|}{ Resultados } \\
\hline & & & & \multirow{2}{*}{$\begin{array}{c}240(J)-1^{\circ} \\
d h\end{array}$} & \multirow{2}{*}{$\begin{array}{c}240(J)-3^{\circ} \\
d h r\end{array}$} & \multicolumn{2}{|c|}{ Ocorrências } \\
\hline & & & & & & $120,240,360,480(\mathrm{~J})$ & 720 e $960(\mathrm{~J})$ \\
\hline padrão $\mathrm{COHAB}$ & 2,84 & 11,40 & 2,30 & 1,70 & 0,00 & sem ocorrências & $\begin{array}{l}\text { destacamento da argamassa } \\
\text { do lado ext. da parede e } \\
\text { fissura vertical no lado } \\
\text { interno. }\end{array}$ \\
\hline B & 2,57 & 10,30 & 2,10 & 0,50 & 0,10 & sem ocorrências & sem ocorrências \\
\hline $\mathrm{C}$ & 2,73 & 11,00 & 2,20 & 13,00 & 0,10 & $\begin{array}{l}\text { fissura na junta direita - lado } \\
\text { externo da parede }\end{array}$ & $\begin{array}{l}\text { aumento da fissura e nova } \\
\text { fissura do lado interno na } \\
\text { mesma junta }\end{array}$ \\
\hline $\mathrm{D}$ & 2,50 & 10,00 & 2,00 & 7,10 & 0,00 & $\begin{array}{l}\text { fissuras nas juntas - face } \\
\text { externa da parede }\end{array}$ & $\begin{array}{l}\text { novas fissuras nas juntas - } \\
\text { face ext. e fissura com } \\
\text { lascamento do tijolo - face } \\
\text { interna da parede }\end{array}$ \\
\hline $\mathrm{E}$ & 2,50 & 10,00 & 2,00 & 0,00 & 0,00 & sem ocorrências & sem ocorrências \\
\hline $\mathrm{F}$ & 2,71 & 11,00 & 2,20 & 1,10 & 0,00 & sem ocorrências & sem ocorrências \\
\hline $\mathrm{G}$ & 2,88 & 11,50 & 2,30 & 3,00 & 0,10 & sem ocorrências & sem ocorrências \\
\hline $\mathrm{H}$ & 3,00 & 12,00 & 2,40 & 32,50 & 0,00 & $\begin{array}{l}\text { rachadura da coluna de } \\
\text { sustentação do painel - lado } \\
\text { externo e das travessas de } \\
\text { fechamento e travamento - } \\
\text { lado interno }\end{array}$ & $\begin{array}{l}\text { rompimento da coluna de } \\
\text { sustentação ext. e aumento } \\
\text { da rachadura das travessas - } \\
\text { lado interno. Afundamento } \\
\text { do painel - ruptura }\end{array}$ \\
\hline I & 2,50 & 10,00 & 2,00 & 1,80 & 0,00 & $\begin{array}{l}\text { fissura na junta do painel - } \\
\text { face interna da parede }\end{array}$ & sem ocorrências \\
\hline $\mathrm{J}$ & 2,80 & 11,20 & 2,20 & 0,40 & 0,00 & sem ocorrências & sem ocorrências \\
\hline $\mathrm{K}$ & 2,68 & 11,00 & 2,10 & 5,80 & 0,00 & $\begin{array}{l}\text { fissuras diagonais e nas juntas } \\
\text { do lado interno e externo }\end{array}$ & $\begin{array}{l}\text { aumento das fissuras e } \\
\text { ruptura de } 2 \text { painéis } \\
\text { centrais. Um deles destacou- } \\
\text { se da junta de travamento }\end{array}$ \\
\hline
\end{tabular}




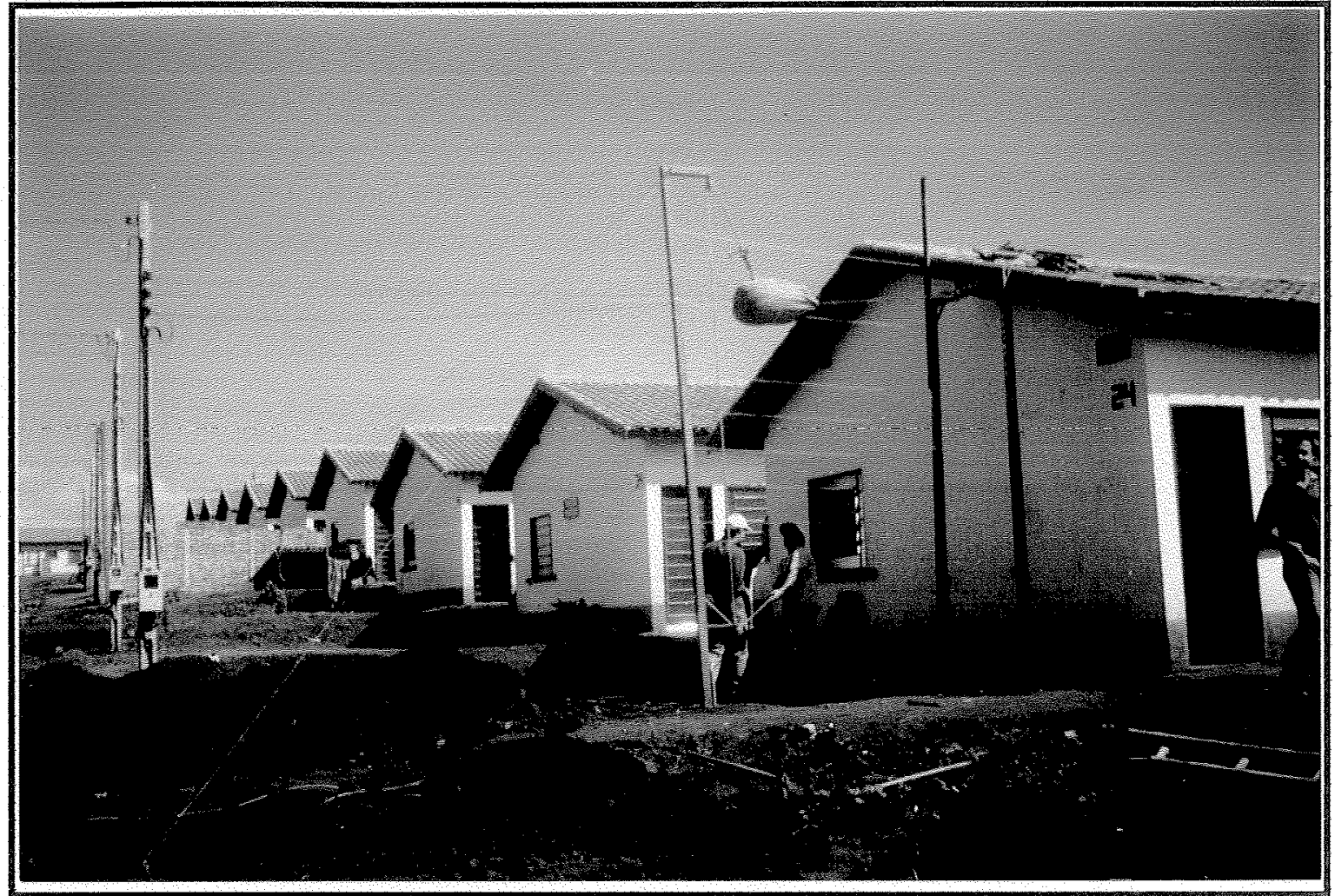

Figura 14 - Sistema construtivo convencional - padrão COHAB. Vista do ensaio.

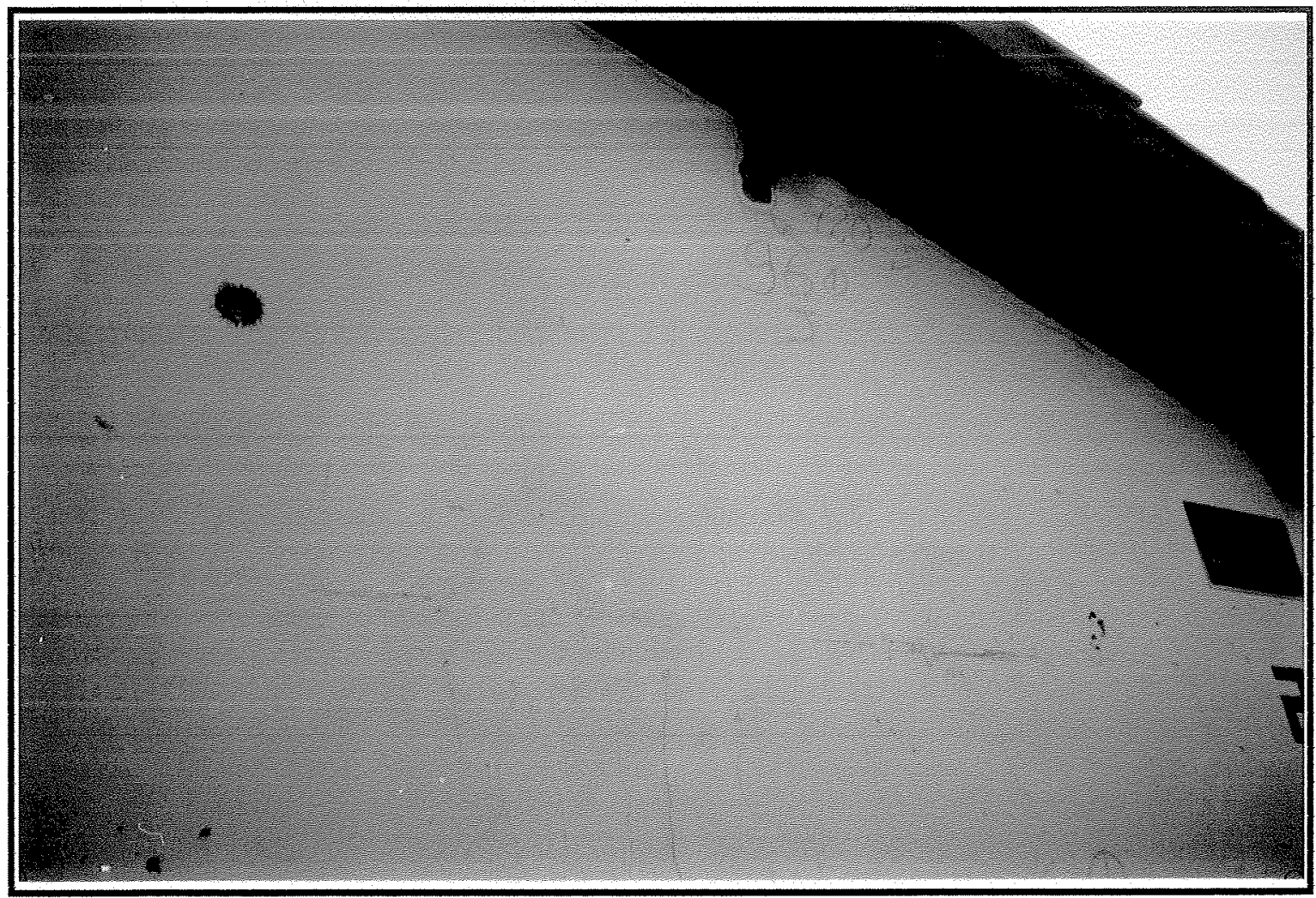

Figura 15 - Sistema construtivo convencional - padrão COHAB. Aspecto externo da parede ensaiada após o impacto de 960J. 


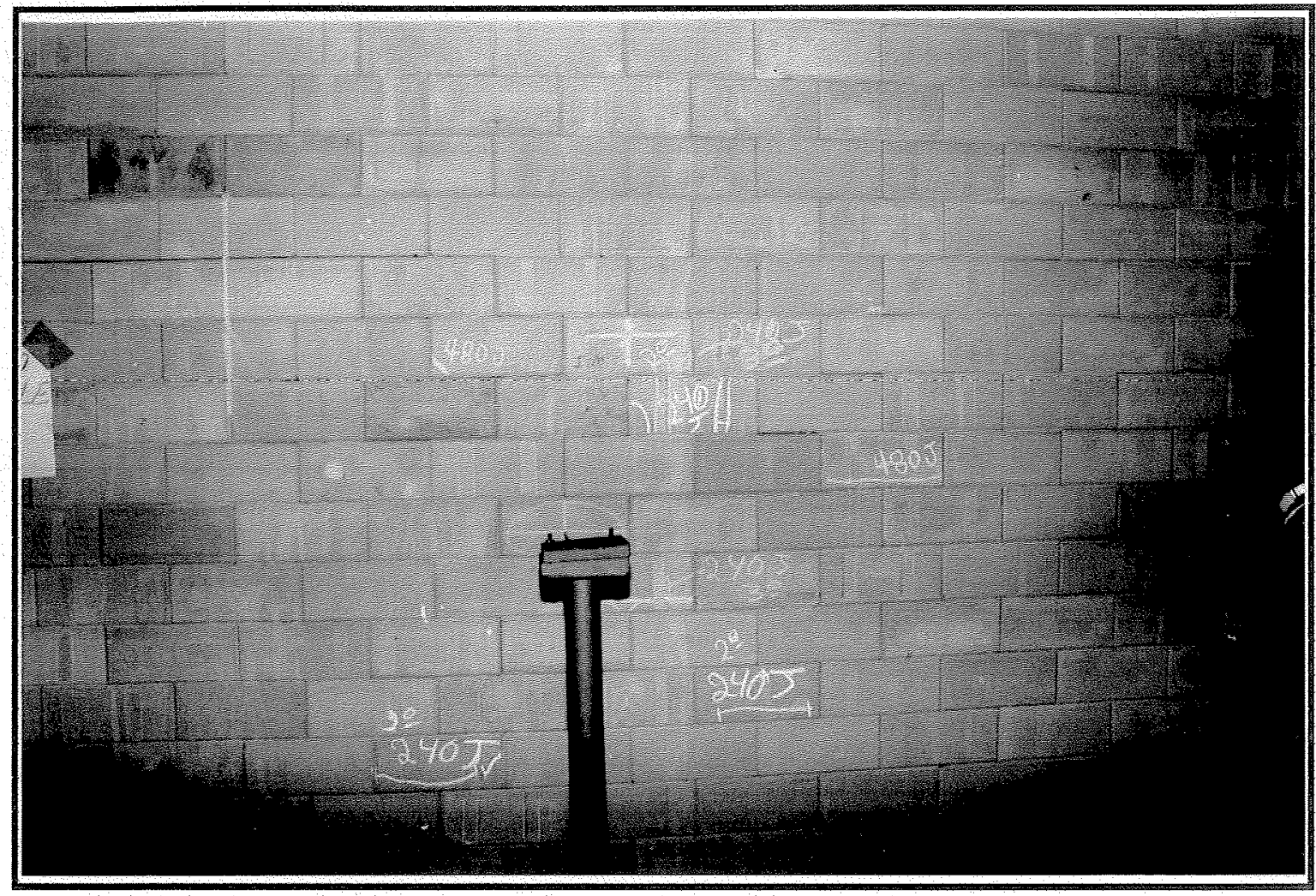

Figura 16 - Sistema construtivo D. Vista interna da parede ensaiada.

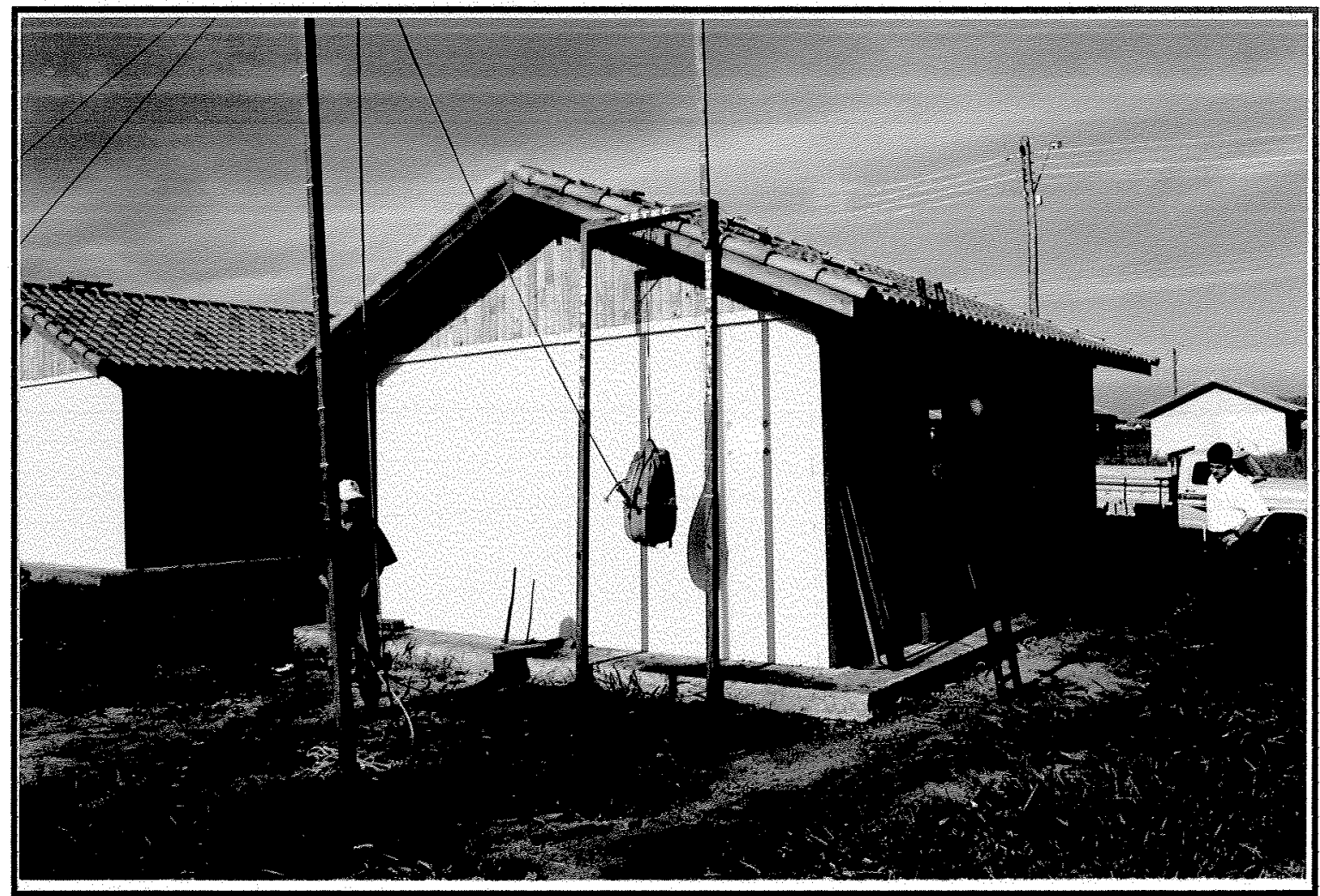

Figura 17 - Sistema construtivo I. Preparativos para o ensaio. 


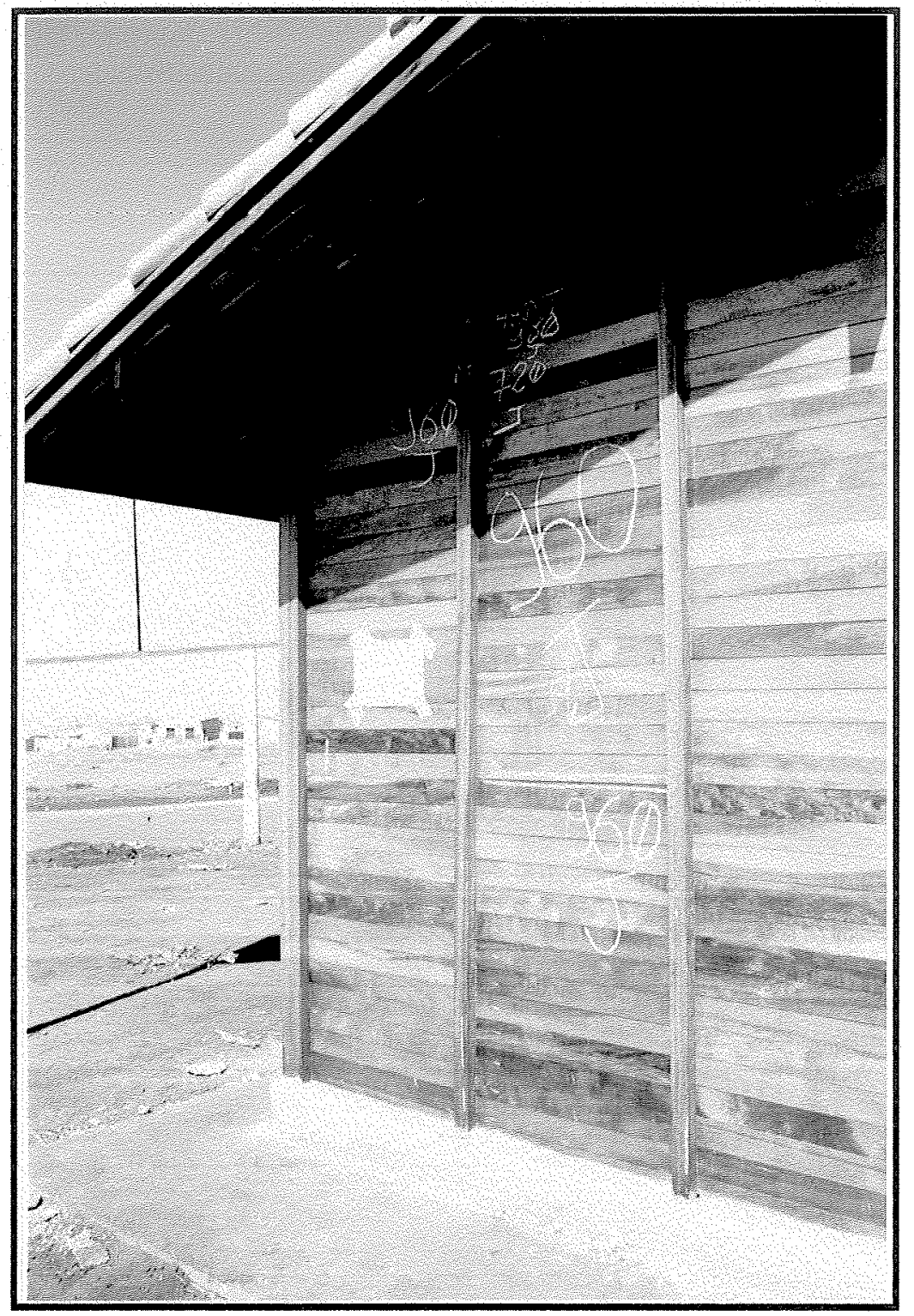

Figura 18 - Sistema construtivo $\mathrm{H}$. Configuração do estado de ruína da parede. Lado externo. Impacto com energia de 960J. 


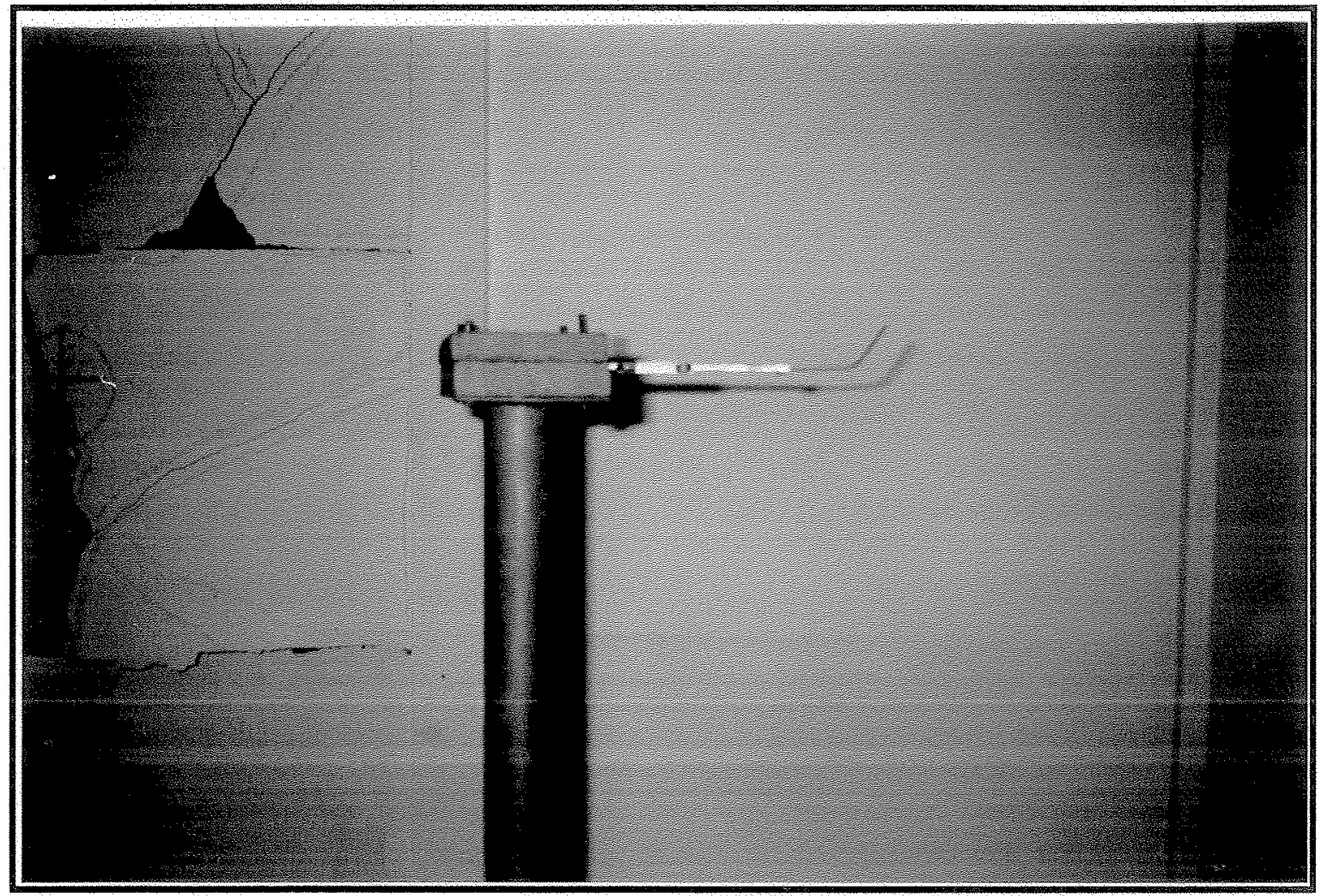

Figura 19 - Sistema construtivo K. Estado final do sistema para medição das deformações horizontais após impacto de $720 \mathrm{~J}$. 


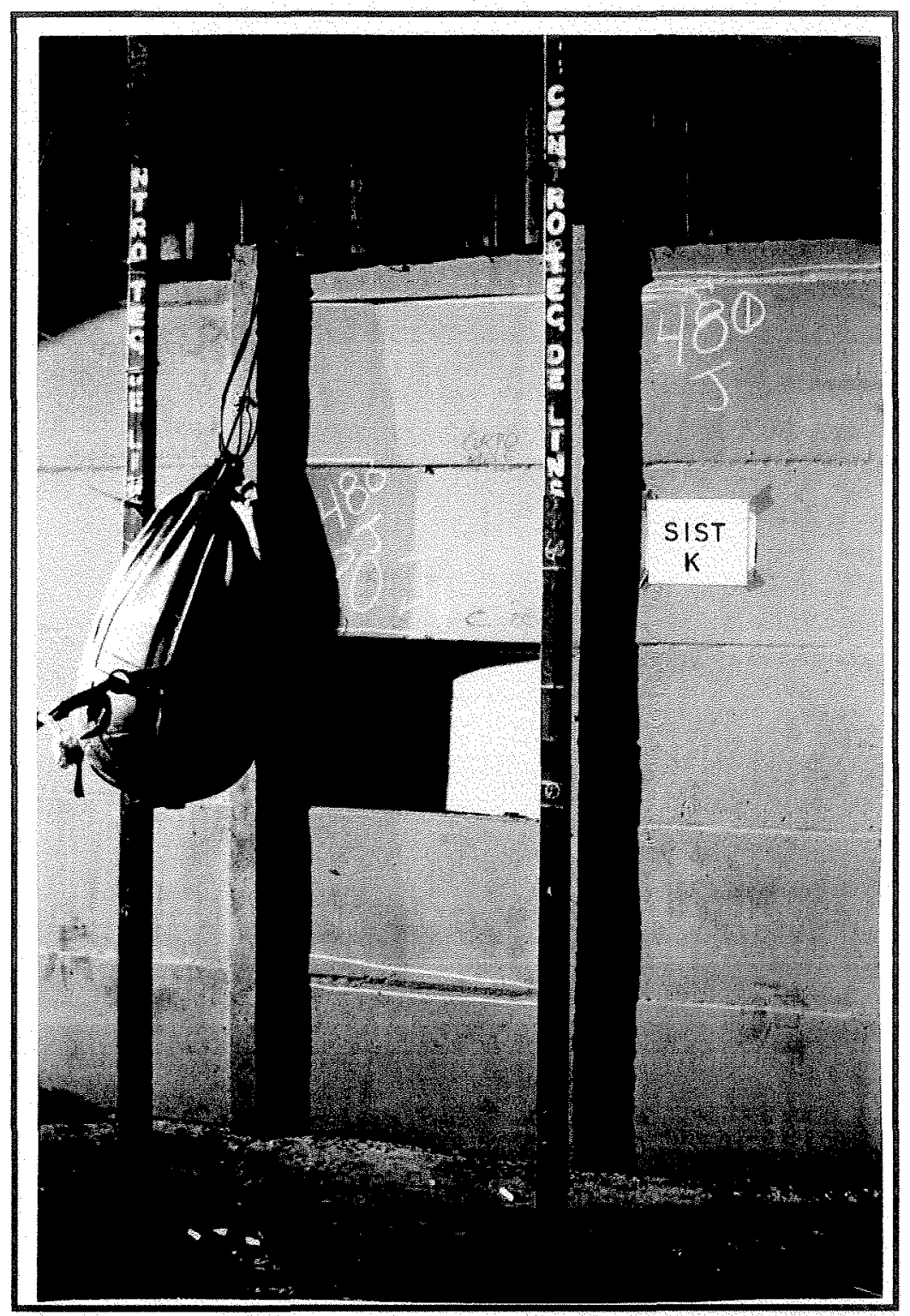

Figura 20 - Sistema construtivo K. Configuração do estado de ruína do painel. Vista externa após impacto de 720J. 


\subsubsection{Ensaio de verificação do comportamento sob ação de impactos de corpo duro de pequena e grande dimensão}

Os resultados de interesse, pertinentes ao ensaio, consistem na profundidade máxima das mossas registradas durante os impactos com energia de $3,75 \mathrm{~J}$ e na ocorrência de danos ou transpassamento da parede com os impactos de 20J. Desta forma, os resultados obtidos, para cada um dos sistemas construtivos analisados, foram agrupados e podem ser vistos na tabela 02.

Confrontando-se os resultados obtidos com os critérios de desempenho assumidos, observou-se que, de maneira geral, todos os sistemas construtivos analisados tiveram um bom comportamento, com relação às paredes externas, sob ação de impactos de corpo duro.

As ocorrências registradas durante os impactos de $3,75 \mathrm{~J}$ nos sistemas $\mathrm{A}$ e $\mathrm{H}$ foram consideradas de pequena monta pois, não foram observadas mossas superiores ao limite permitido de $2,0 \mathrm{~mm}$.

Apenas o sistema construtivo $\mathrm{J}$ apresentou uma profundidade de mossa superior ao limite máximo admitido. Este resultado deve-se mais ao engrossamento do revestimento da parede, acarretado por falhas na colocação dos blocos, do que à resistência da parede. Tal fato fica evidenciado pela ocorrência registrada de desprendimento localizado do revestimento. 
Tabela 02 - Resumo dos resultados referentes ao ensaio de impactos de corpo duro de pequena e grande dimensão

\begin{tabular}{|c|c|c|c|c|c|}
\hline \multirow{2}{*}{$\begin{array}{c}\text { Sistemas } \\
\text { construtivos }\end{array}$} & \multirow{2}{*}{$\begin{array}{c}\text { Componente } \\
\text { ensaiado }\end{array}$} & \multirow{2}{*}{$\begin{array}{l}\text { Limitações } \\
\text { dmáx.(mm) }\end{array}$} & \multirow{2}{*}{$\begin{array}{c}\text { Profund. máx. 3,75 } \\
\text { d (mm) }\end{array}$} & \multicolumn{2}{|c|}{ Ocorrências } \\
\hline & & & & $3,75(\mathrm{~J})$ & $20(\mathrm{~J})$ \\
\hline padrão $\mathrm{COHAB}$ & parede externa & 2,00 & 1,00 & $\begin{array}{l}\text { marca no } \\
\text { revestimento }\end{array}$ & sem ocorrências \\
\hline B & parede externa & 2,00 & 0,00 & sem ocorrências & sem ocorrências \\
\hline $\mathrm{C}$ & parede externa & 2,00 & 0,00 & sem ocorrências & sem ocorrências \\
\hline $\mathrm{D}$ & parede externa & 2,00 & 1,00 & sem ocorrências & sem ocorrências \\
\hline $\mathrm{E}$ & parede externa & 2,00 & 0,50 & sem ocorrências & sem ocorrências \\
\hline $\mathrm{F}$ & parede externa & 2,00 & 1,00 & sem ocorrências & sem ocorrências \\
\hline $\mathrm{G}$ & parede externa & 2,00 & 0,90 & sem ocorrências & sem ocorrências \\
\hline $\mathrm{H}$ & parede externa & 2,00 & 0,00 & peq. marca no verniz & sem ocorrências \\
\hline I & parede externa & 2,00 & 0,50 & sem ocorrências & sem ocorrências \\
\hline $\mathrm{J}$ & parede externa & 2,00 & 3,40 & $\begin{array}{l}\text { desprendimento do } \\
\text { revestimemto }\end{array}$ & sem ocorrências \\
\hline $\mathrm{K}$ & parede externa & 2,00 & 0,00 & sem ocorrências & sem ocorrências \\
\hline
\end{tabular}

dmáx. - máximo admitido pelo critério

$\mathrm{d}$ - profundidade da mossa 


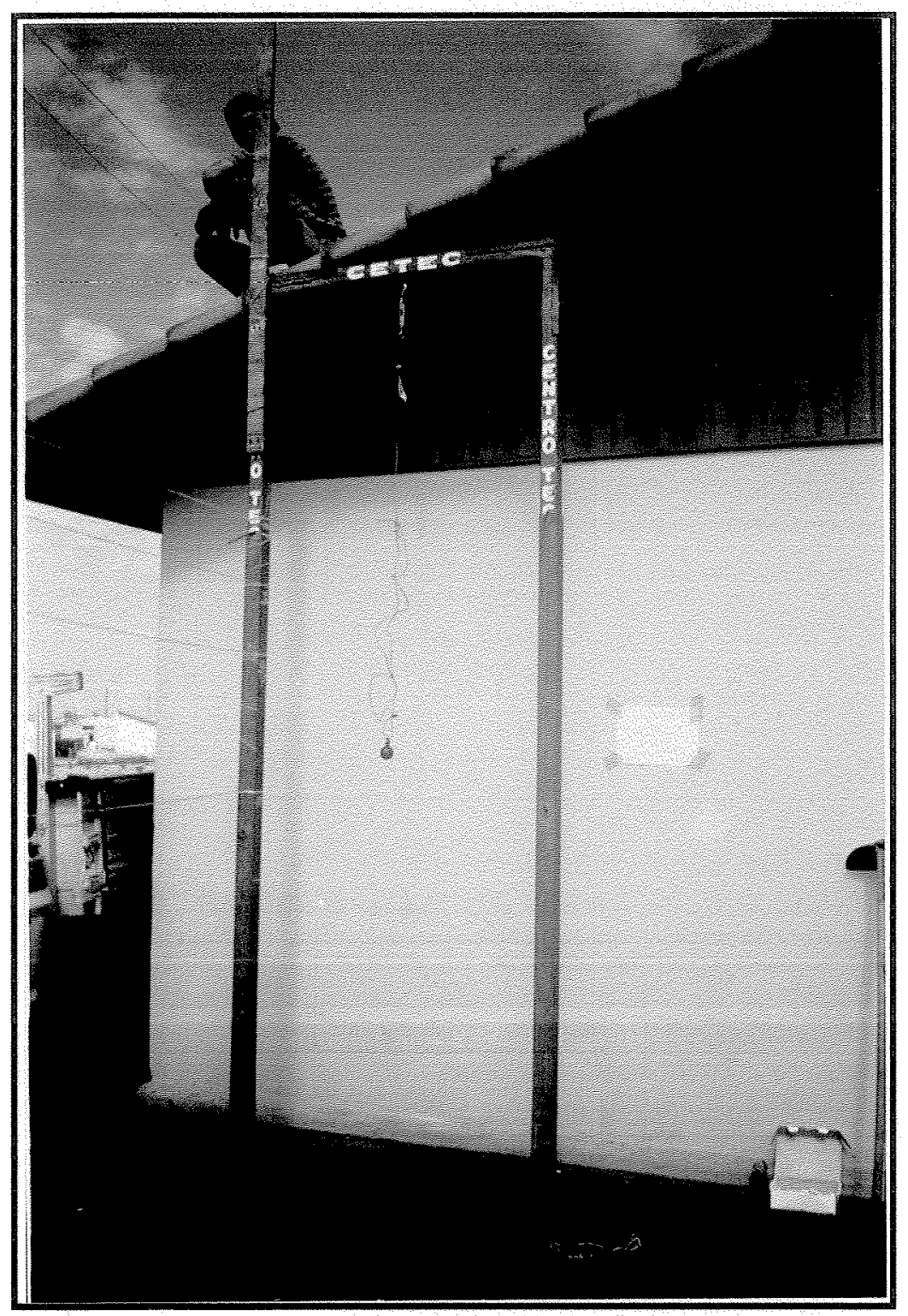

Figura 21 - Sistema construtivo I. Vista do ensaio com esfera de 0,5kg. 


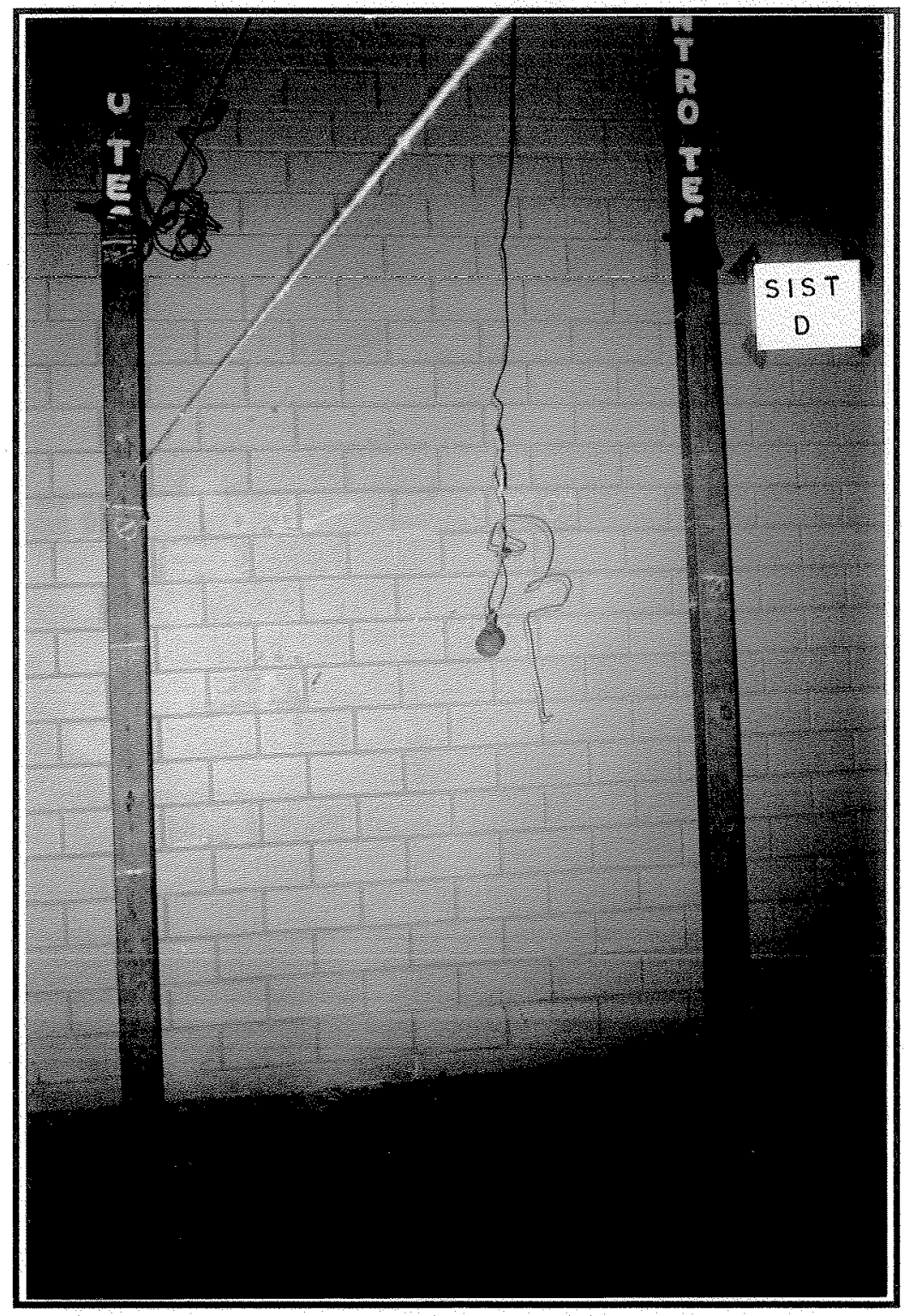

Figura 22 - Sistema construtivo D. Vista do ensaio com esfera de 1,0kg. 


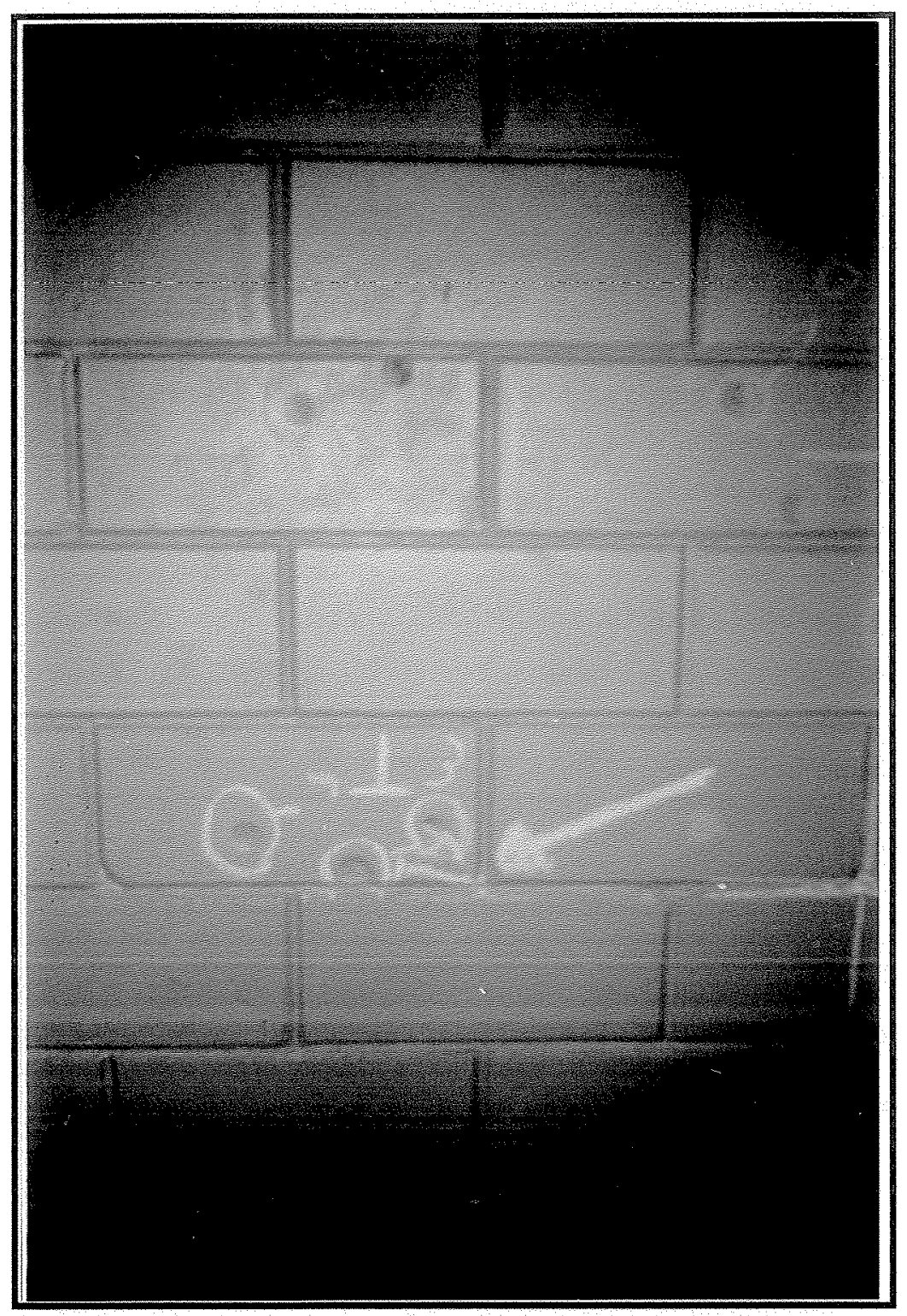

Figura 23 - Sistema construtivo D. Mossas produzidas pelos impactos. 


\subsubsection{Ensaio de verificação do comportamento sob ação de cargas provenientes de peças suspensas}

Os elementos ensaiados, referem-se em sua totalidade às paredes internas submetidas a cargas provenientes de peças suspensas onde não devem ocorrer fissuras, rupturas ou arrancamento dos dispositivos de fixação. As deformações instantâneas e residuais não devem ultrapassar h/500 e h/2500 respectivamente.

A fixação do dispositivo de aplicação do carregamento foi efeluado da mesma forma em todos os sistemas construtivos, através de bucha de náilon comum, S-8, com parafuso de rosca soberba.

O sinal negativo nos valores das deformações, indicam movimento no sentido da face carregada. O sinal positivo, movimento contrário.

a) Sistema construtivo convencional - padrão COHAB

Estes resultados, que satisfazem plenamente os requisitos quanto às deformações, instantânea e residual máximas admitidas, foram obtidos após a terceira tentativa de fixação.

Na primeira tentativa, ao se atingir o carregamento parcial de $600 \mathrm{~N}$ (60kgf), ocorreu o arrancamento do sistema de fixação do dispositivo de aplicação da carga. Na segunda tentativa, em outra parede interna, utilizou-se bucha de náilon S-10, cortada, sem que a fixação ficasse satisfatória. Na última tentativa, utilizou-se bucha de náilon comum, $\mathrm{S}-8$, com bom resultado.

\section{b) Sistema construtivo $\mathbf{B}$}

Após a montagem do ensaio, funcionários da empresa trabalharam no recinto onde estavam instalados os aparelhos, utilizados para medida das deformações. Apesar da recomendação dada, os resultados anotados após 24 horas indicaram alteração na posição do suporte dos aparelhos, provavelmente por algum esbarrão. O ensaio ficou, então, prejudicado. 
c) Sistema construtivo $\mathbb{C}$

Não houve observação de quaisquer danos nas faces do painel analisado, bem como na parede como um todo.

Os máximos valores das deformações instantâneas e residuais, medidos $(-0,33 \mathrm{~mm}$ e $-0,21 \mathrm{~mm})$, foram bastante inferiores aos valores máximos admissiveis.

d) Sistema construtivo D

Não foram observadas ocorrências de danos nas faces da parede ensaiada. O máximo valor da deformação horizontal, anotado, após 24 horas de permanência da carga, $(0,53 \mathrm{~mm})$ é muito inferior ao máximo admitido $(5,00 \mathrm{~mm})$. A mesma observação é válida para a deformação residual do ensaio $(-0,29 \mathrm{~mm})$ com relação à perrnissível $(1,00 \mathrm{~mm})$.

e) Sistema construtivo $E$

Não foram observadas ocorrências de danos, nas faces do painel, bem como nas suas interfaces. O valor máximo da deformação horizontal $(-0,21 \mathrm{~mm})$, é significativamente inferior à máxima admitida, tanto quanto a deformação residual $(-0,13 \mathrm{~mm})$.

f) Sistema construtivo $\mathbf{F}$

Não houve observação de ocorrências após a manutenção da carga. As deformações, tanto instantâneas quanto residuais, mantiveram-se bastante abaixo dos valores admissíveis.

g) Sistema construtivo $\mathbf{G}$

Após 24 horas de manutenção da carga, não houve observação de ocorrências. Os valores máximos, das deformações instantânea e residual, foram inferiores aos valores máximos admitidos. 
h) Sistema construtivo $\mathrm{H}$

Após 24 horas de manutenção do carregamento, foi observado empenamento das tábuas que sustentavam o dispositivo da carga. A deformação instantânea máxima anotada, $-3.43 \mathrm{~mm}$, apesar da magnitude é inferior à máxima permitida. A deformação residual máxima de $1.03 \mathrm{~mm}$ está muito próxima do valor limite de 1,20. Neste sistema construtivo, recomenda-se a fixação de peças suspensas nos montantes das paredes, ou em local indicado pelo fabricante.

\section{i) Sistema construtivo I}

Não houve anotação de ocorrência de danos, após a manutenção da carga. A máxima de $1,01 \mathrm{~mm}$ é menor que a máxima admitida. A deformação máxima residual, do ensaio, de 1,00mm está no limite permissivel do critério de desempenho.

\section{j) Sistema construtivo $J$}

Durante as inspeções visuais não foram detectados danos, nem ocorrências com o sistema de fixação. As deformações horizontais instantâneas, bem como as residuais, medidas, foram bem inferiores aos limites máximos, pertinentes ao critério de desempenho.

\section{k) Sistema construtivo $\mathrm{K}$}

Não foram constatados danos de qualquer natureza durante as inspeções nas faces carregada e oposta da parede. As deformações máximas, tanto após a manutenção da carga, quanto residuais, foram inferiores aos limites máximos admitidos.

$\mathrm{Na}$ tabela 03 pode-se observar os resultados obtidos referente a análise do ensaio em questão, bem como as ocorrências de cada sistema construtivo. 
Tabela 03 - Resumo dos resultados referentes ao ensaio de cargas provenientes de peças suspensas

\begin{tabular}{|c|c|c|c|c|c|}
\hline \multirow{2}{*}{$\begin{array}{c}\text { Sistemas } \\
\text { construtivos }\end{array}$} & \multirow{2}{*}{$\begin{array}{c}\text { altura da parede } \\
\mathrm{h}(\mathrm{mm})\end{array}$} & \multirow{2}{*}{$\begin{array}{c}\text { dhmáx. (mm) } \\
\text { h/500 }\end{array}$} & \multirow{2}{*}{$\begin{array}{c}\text { dhrmáx. (mm) } \\
\text { h/2500 }\end{array}$} & \multicolumn{2}{|c|}{ Resultados } \\
\hline & & & & $\mathrm{dh}(\mathrm{mm})$ & $\mathrm{dhr}(\mathrm{mm})$ \\
\hline padrão $\mathrm{COHAB}$ & 2,84 & 5,70 & 1,10 & 0,14 & 0,13 \\
\hline $\mathrm{B}$ & 2,57 & 5,14 & 1,03 & $*$ & $*$ \\
\hline $\mathrm{C}$ & 2,73 & 5,46 & 1,10 & 0,33 & 0,21 \\
\hline $\mathrm{D}$ & 2,50 & 5,00 & 1,00 & 0,75 & 0,53 \\
\hline $\mathrm{E}$ & 2,50 & 5,00 & 1,00 & 0,21 & 0,13 \\
\hline F & 2,71 & 5,42 & 1,10 & 0,03 & 0,03 \\
\hline $\mathrm{G}$ & 2,88 & 5,76 & 1,20 & 0,70 & 0,70 \\
\hline $\mathrm{H}$ & 3,00 & 6,00 & 1,20 & 3,43 & 1,03 \\
\hline $\mathrm{I}$ & 2,50 & 5,00 & 1,00 & 1,01 & 1,00 \\
\hline $\mathbf{J}$ & 2,80 & 5,60 & 1,10 & 0,03 & 0,02 \\
\hline $\mathrm{K}$ & 2,68 & 5,40 & 1,10 & 0,10 & 0,05 \\
\hline
\end{tabular}

* leitura prejudicada

dh - deformação horizontal instantânea

dhr - deformação horizontal residual 


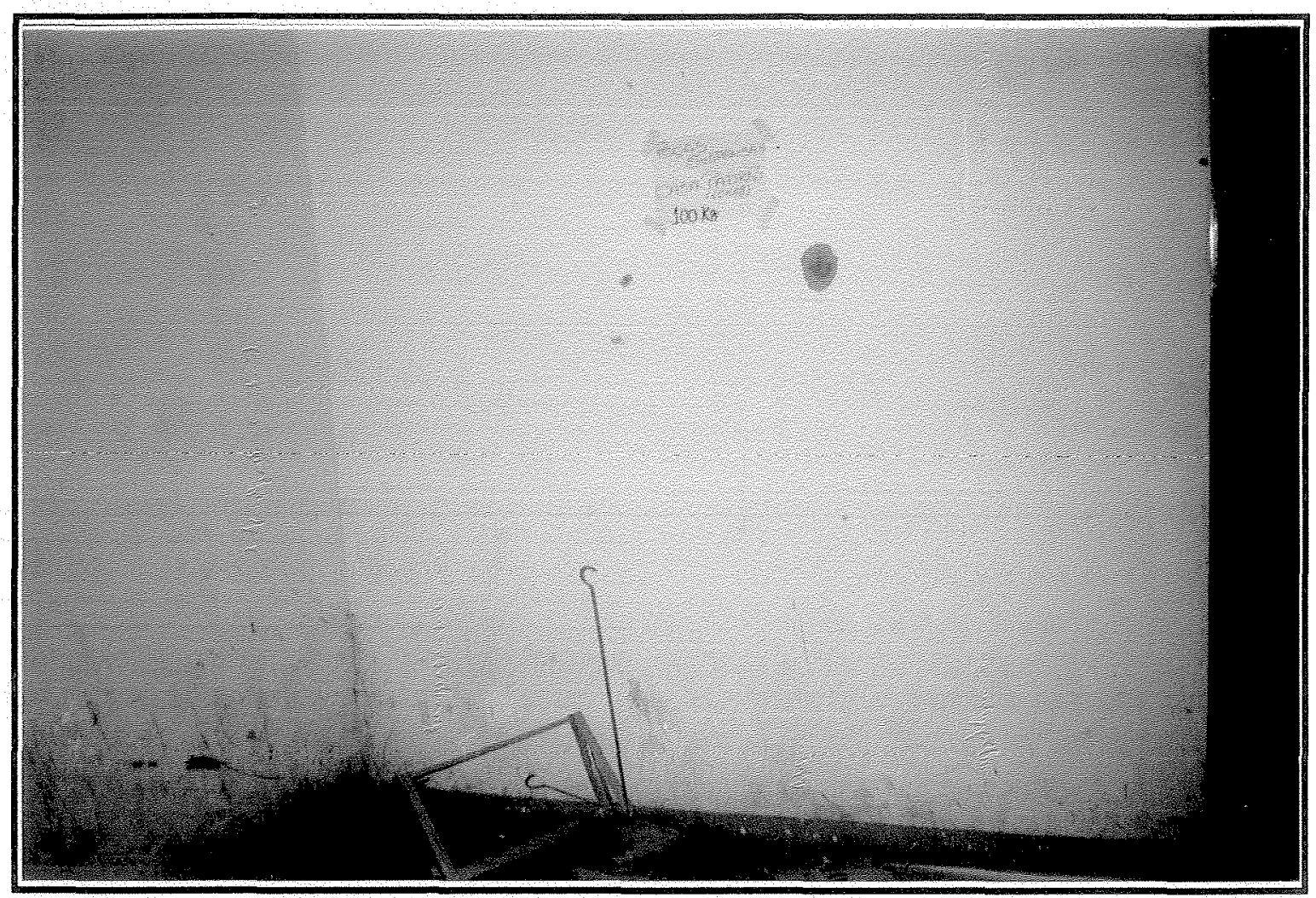

Figura 24 - Sistema construtivo convencional - padrão COHAB. Arrancamento do sistema de fixação com $600 \mathrm{~N}$ de carga total.

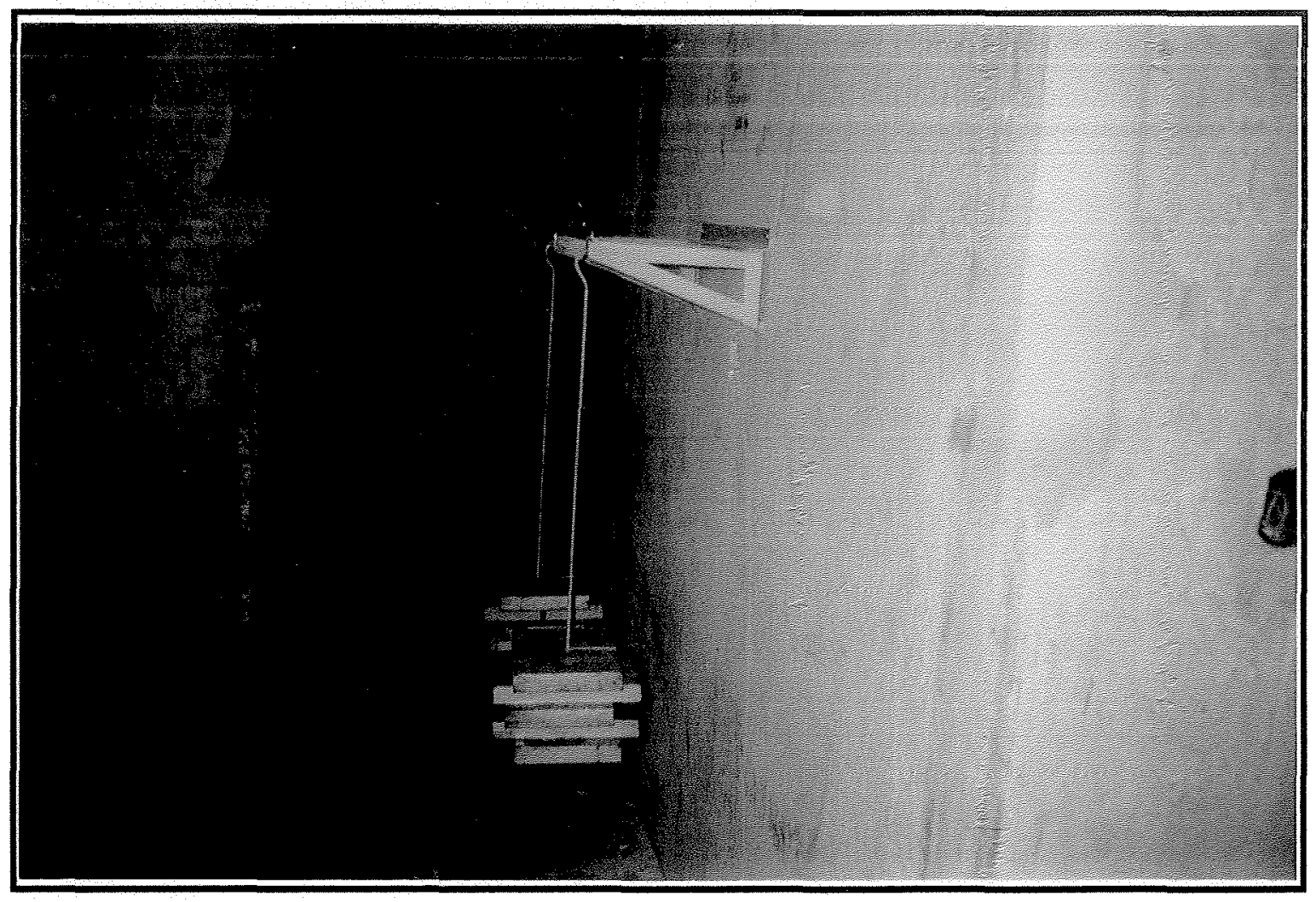

Figura 25 - Sistema construtivo B. Vista do ensaio com carga total aplicada de $1000 \mathrm{~N}$. 


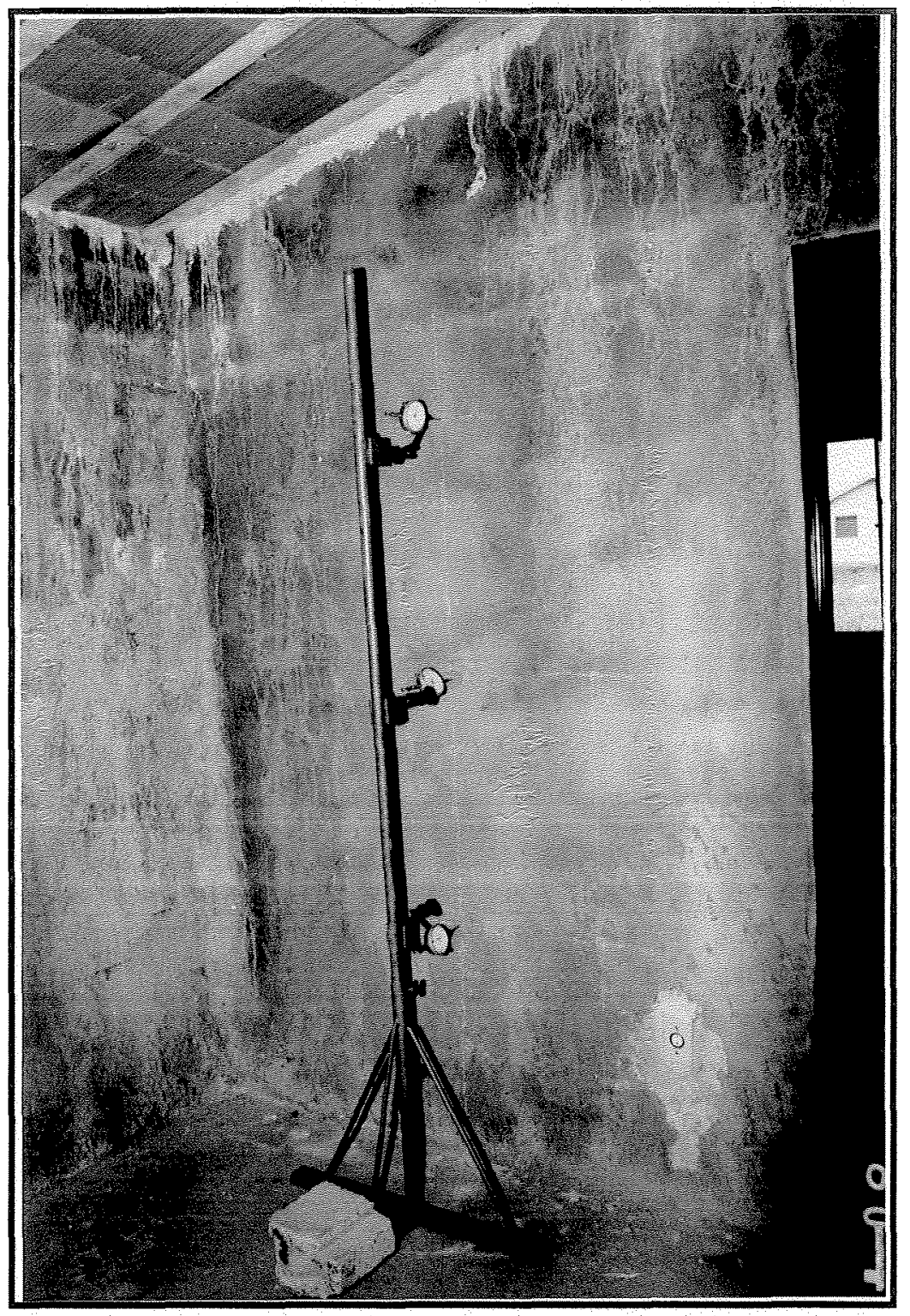

Figura 26 - Sistema construtivo J. Face oposta da parede instrumentada. 


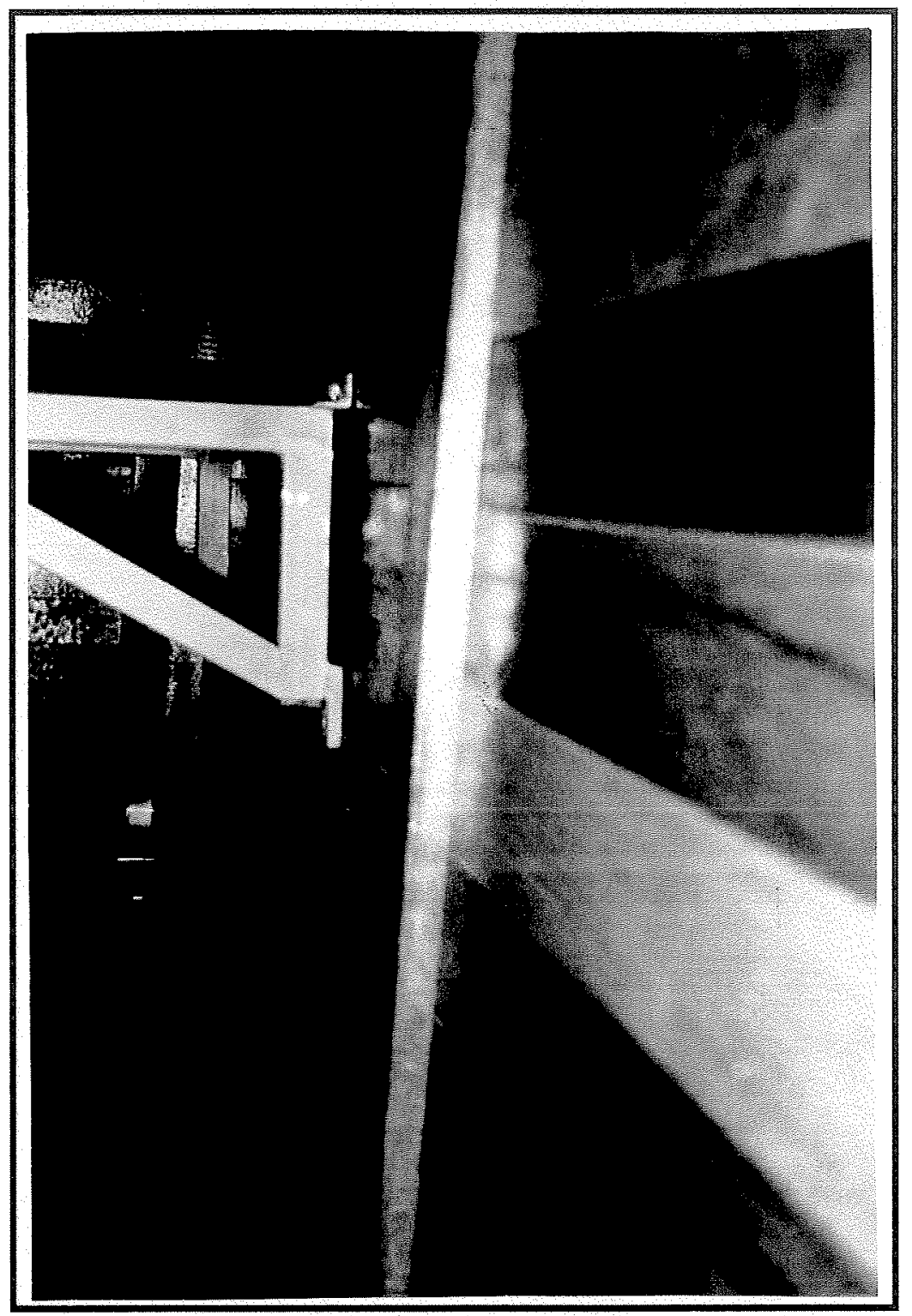

Figura 27 - Sistema construtivo H. Empenamento da prancha no ponto de fixação dos dispositivos de aplicação das cargas. 


\subsubsection{Ensaio de verificação do comportamento sob ação de fechamentos bruscos de portas}

Os resultados do ensaio, de interesse para a avaliação e obtidos por inspeção visual, são facilmente analisáveis. Foram, portanto, registradas as ocorrências de danos de qualquer natureza, para o confronto com os critérios de desempenho.

Desta forma, os registros das inspeçōes, para cada um dos sistemas construtivos analisados, foram agrupados e podem ser vistos na tabela 04.

Vale ressaltar que este ensaio avalia tanto as paredes quanto as folhas de portas quando submetidas à solicitações, sendo que, como pretendia-se avaliar as paredes, estas não devem apresentar avarias graves nem rupturas.

De maneira geral, observou-se que as folhas das portas externas empregadas nos sistemas construtivos analisados, apresentaram-se com significativa fragilidade. Nos sistemas construtivos $F$ e $G$ o ensaio foi encerrado no $7^{\circ}$ fechamento brusco pois, houve ruptura da folha da porta.

Os sistemas construtivos $\mathrm{B}, \mathrm{C}, \mathrm{E} \mathrm{e} \mathrm{J}$ apresentaram pequenas fissuras no contorno do batente e/ou desprendimento do revestimento.

As paredes externas analisadas, dos demais sistemas construtivos apresentaram bom comportamento, com exceção do sistema construtivo $\mathrm{H}$, devido a diminuição da rigidez do conjunto painel/porta. 


\begin{tabular}{|c|c|}
\hline Sistemas construtivos & Registro das ocorrências \\
\hline padrão $\mathrm{COHAB}$ & danos na fechadura; funcionabilidade da chave prejudicada; sem danos à parede \\
\hline $\mathbb{B}$ & $\begin{array}{l}\text { fissura no contomo do batente na parte superior direita, face interna; fissura no rejuntamento do } \\
\text { revestimento extemo }\end{array}$ \\
\hline $\mathrm{C}$ & fissura vertical na junção painel/marco, lado esquerdo face interna da parede \\
\hline$D$ & afundamento da porta na região da fechadura; sem danos à parede \\
\hline $\mathbb{E}$ & $\begin{array}{l}\text { fissuras no entomo do batente; destacamento na região de fixação esquerda; desprendimento do } \\
\text { revestimento na parte superior do batente, face interna }\end{array}$ \\
\hline F & ruptura da folha da porta; sem danos à parede; ensaio encerrado no $7^{\circ}$ fechamento brusco \\
\hline $\mathrm{G}$ & ruptura da folha da porta; sem danos à parede; ensaio encerrado no $7^{\circ}$ fechamento brusco \\
\hline $\mathrm{H}$ & lascamento da guamição superior do batente; diminuição da tigidez do conjunto painelporta \\
\hline $\mathbb{I}$ & ruptura da folha na região da fechadura e no canto inferior esquerdo; sem danos à parede \\
\hline$J$ & $\begin{array}{l}\text { destacamento do batente na parte externa; fissura vertical na parede próximo ao batente, face interna } \\
\text { inferior }\end{array}$ \\
\hline $\mathbb{K}$ & $\begin{array}{l}\text { ruptura da solda entre o montante da porta e o perfil de sustentação do vidro na região da fechadura; } \\
\text { funcionabilidade da fechadura prejudicada }\end{array}$ \\
\hline
\end{tabular}




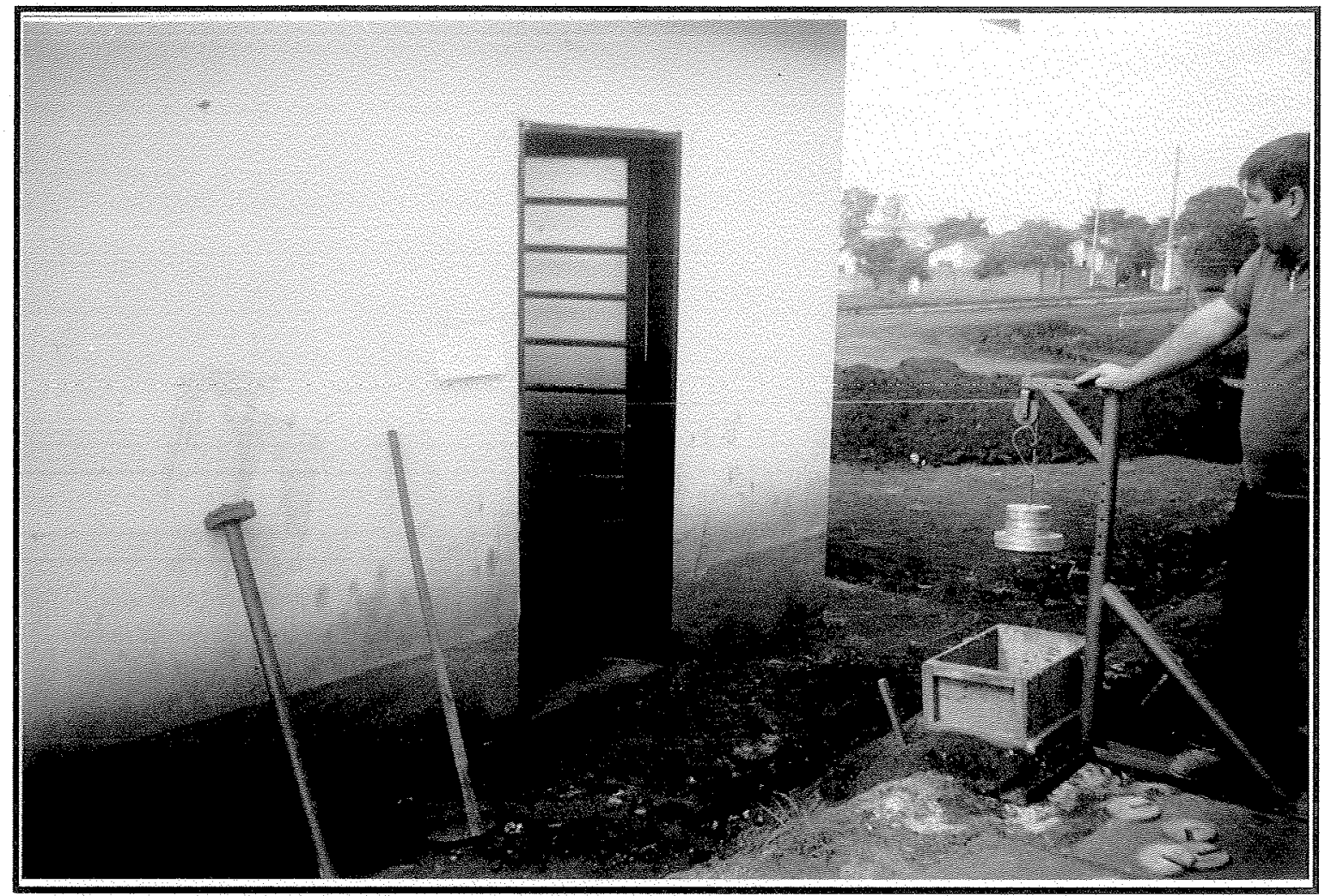

Figura 28 - Sistema Construtivo convencional - padrão COHAB. Vista do ensaio.

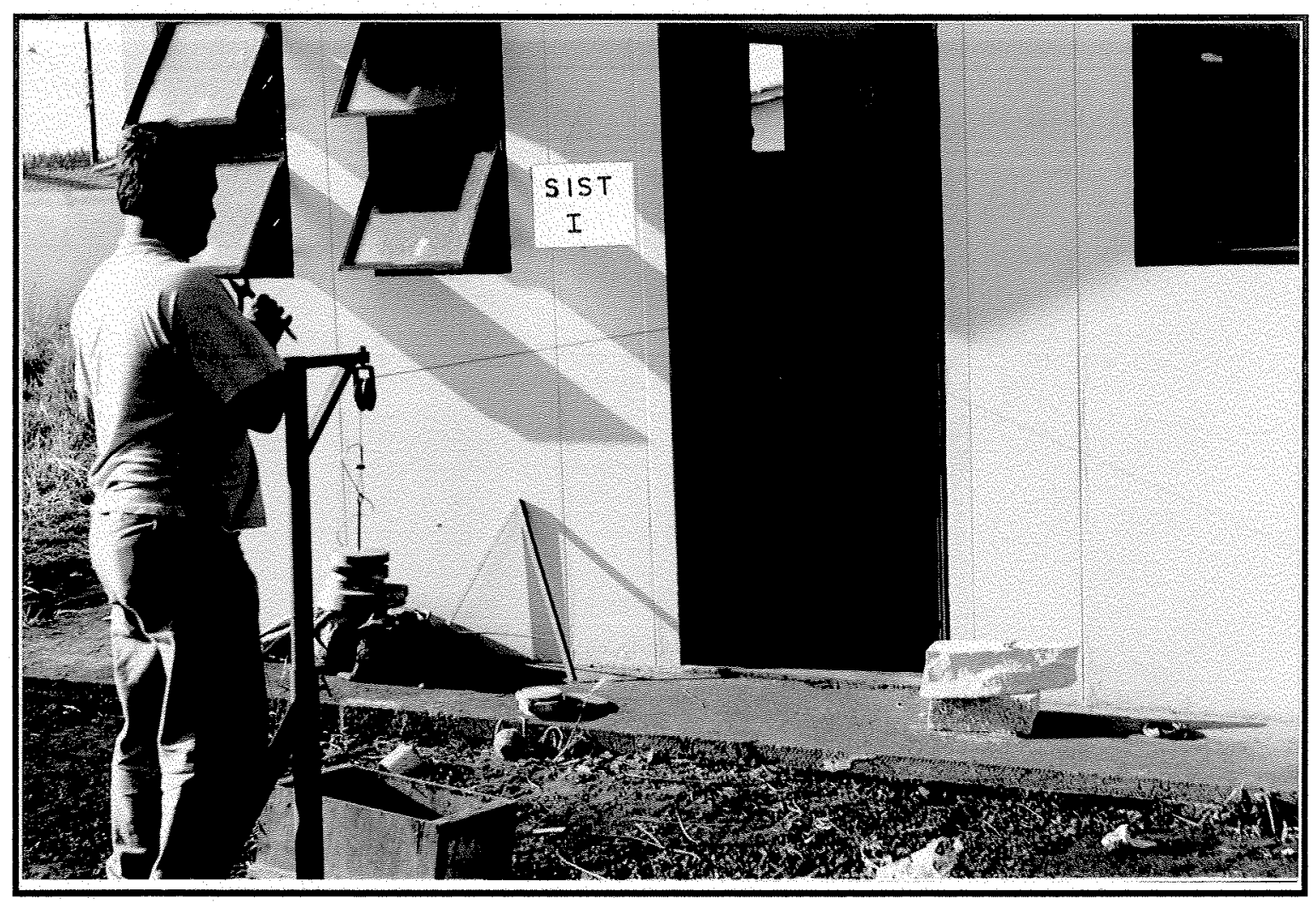

Figura 29 - Sistema construtivo I . Vista do ensaio. 


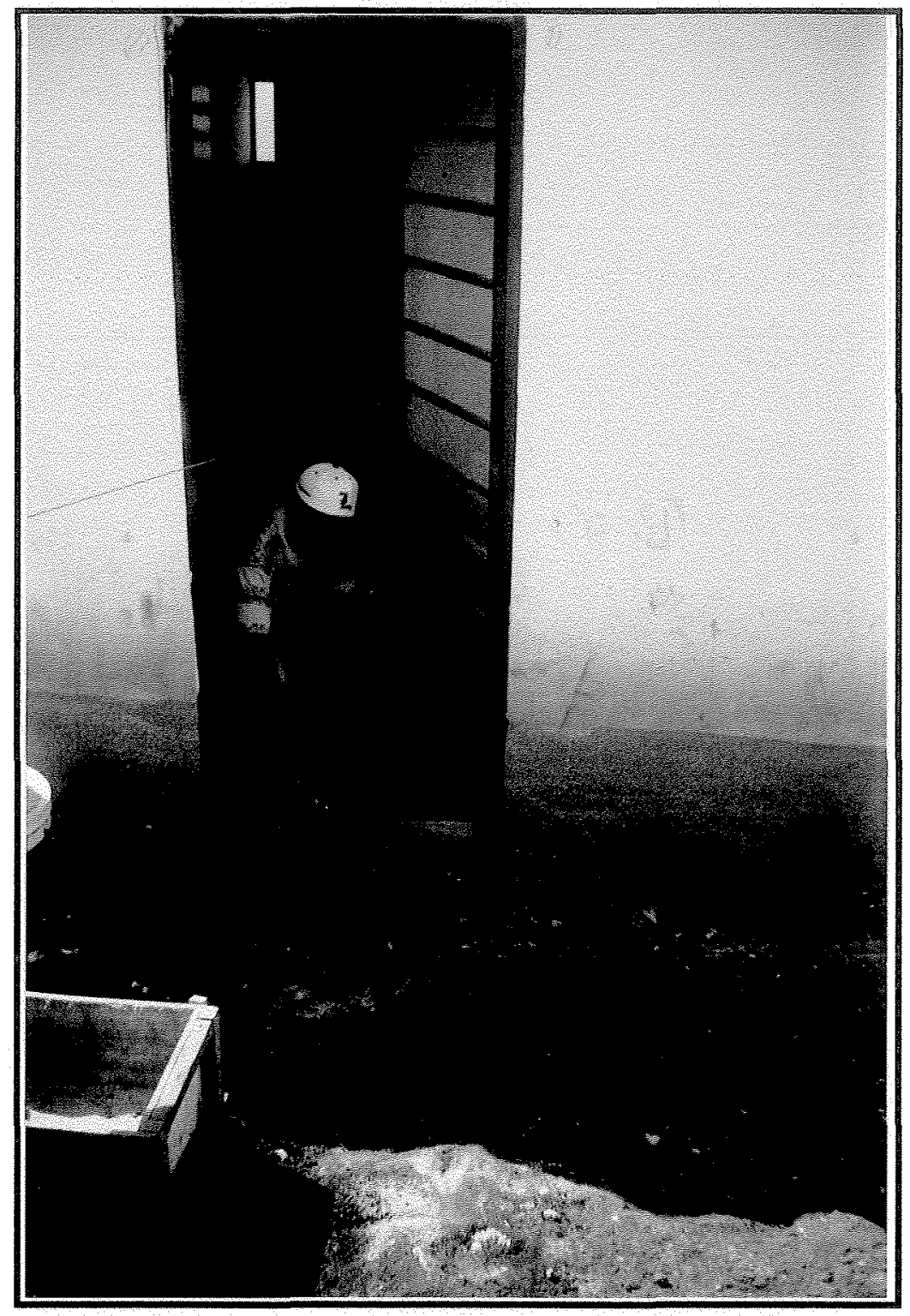

Figura 30 - Sistema construtivo convencional - padrão COHAB. Dispositivo para marcar a inclinação da porta de $60^{\circ} \mathrm{com}$ o plano da parede. 


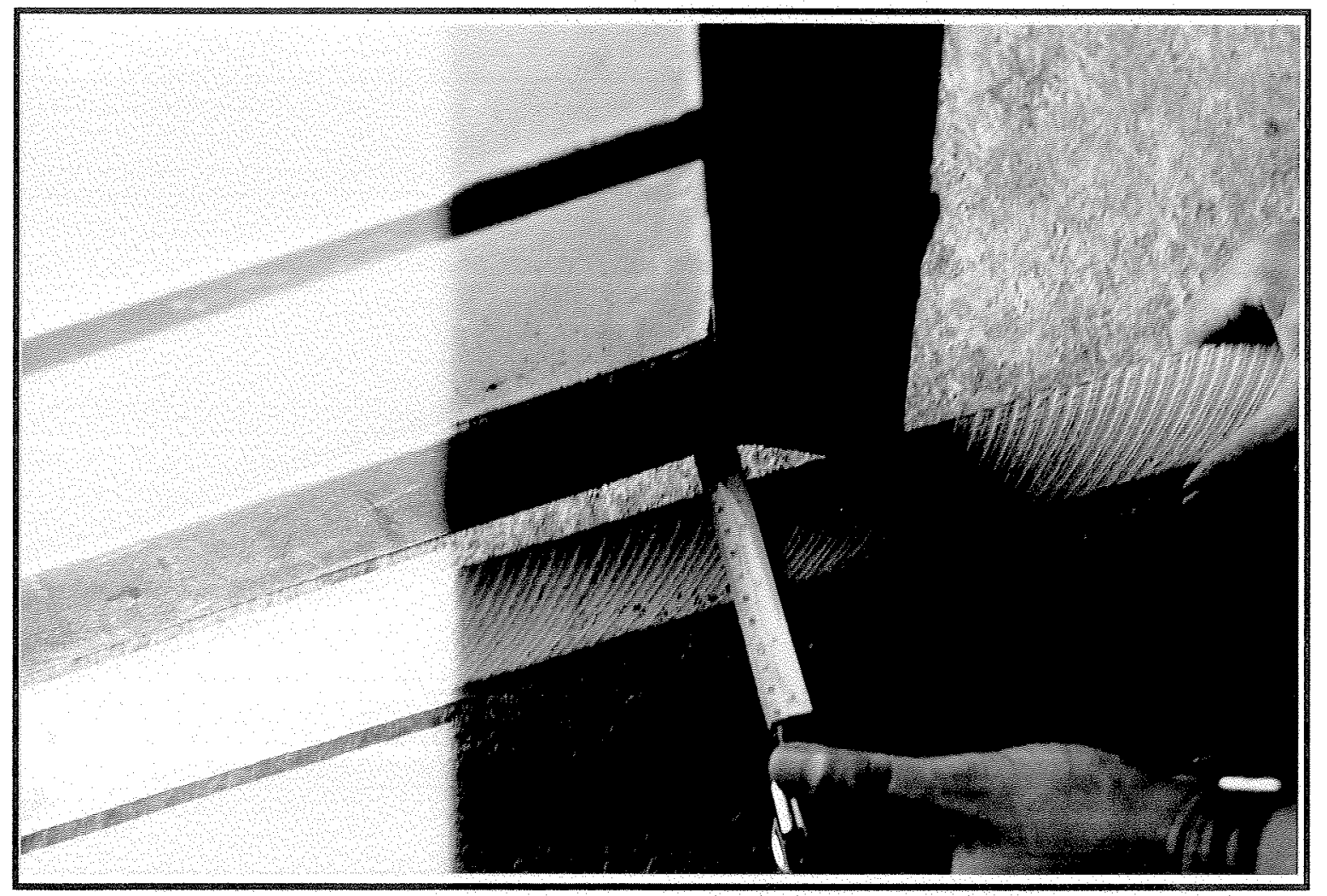

Figura 31 - Sistema construtivo F. Detalhe da ruptura da folha no $7^{\circ}$ fechamento brusco. 


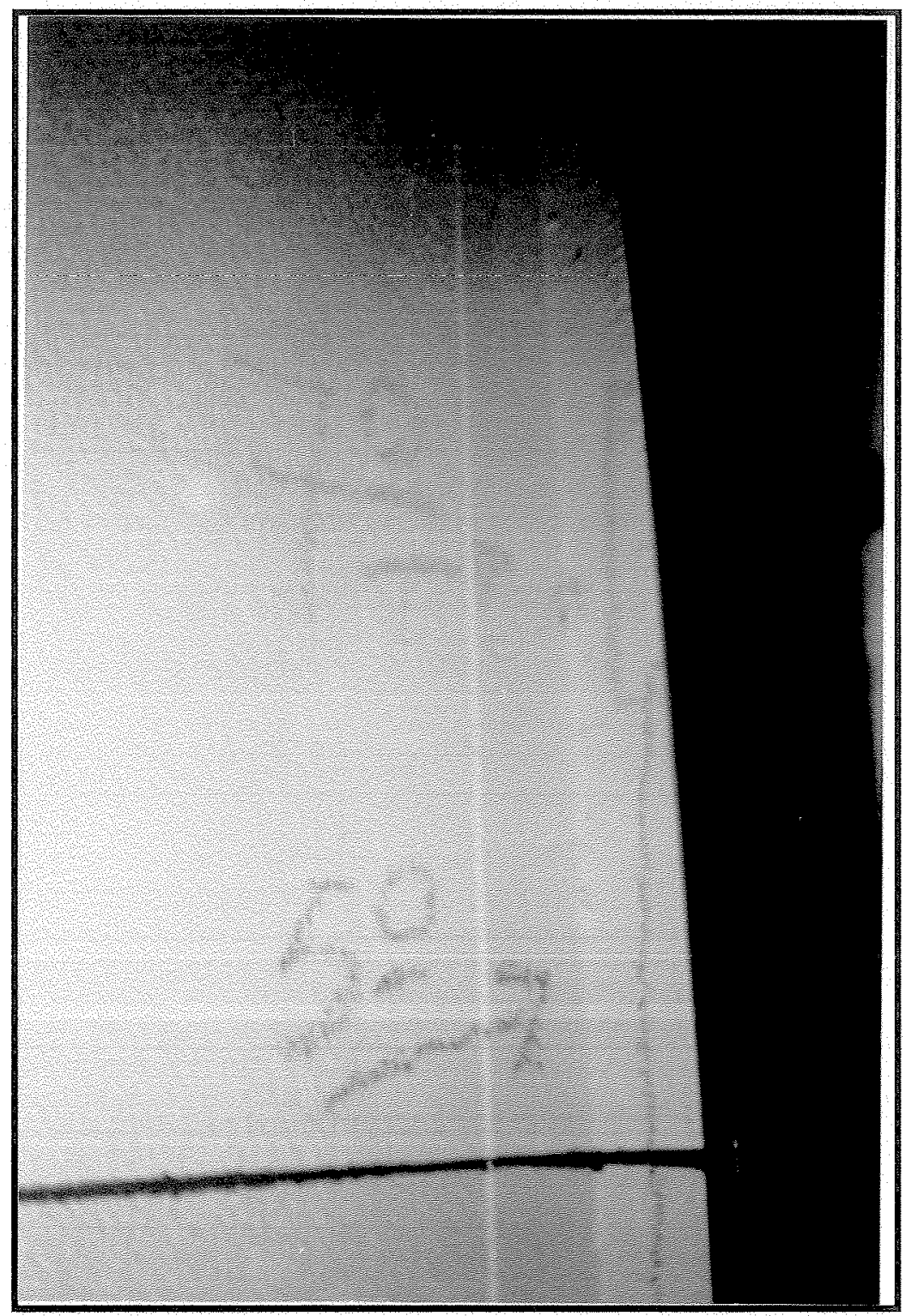

Figura 32 - Sistema construtivo $\mathrm{C}$. Detalhe das fissuras painel/marco na região de fixação do marco. 


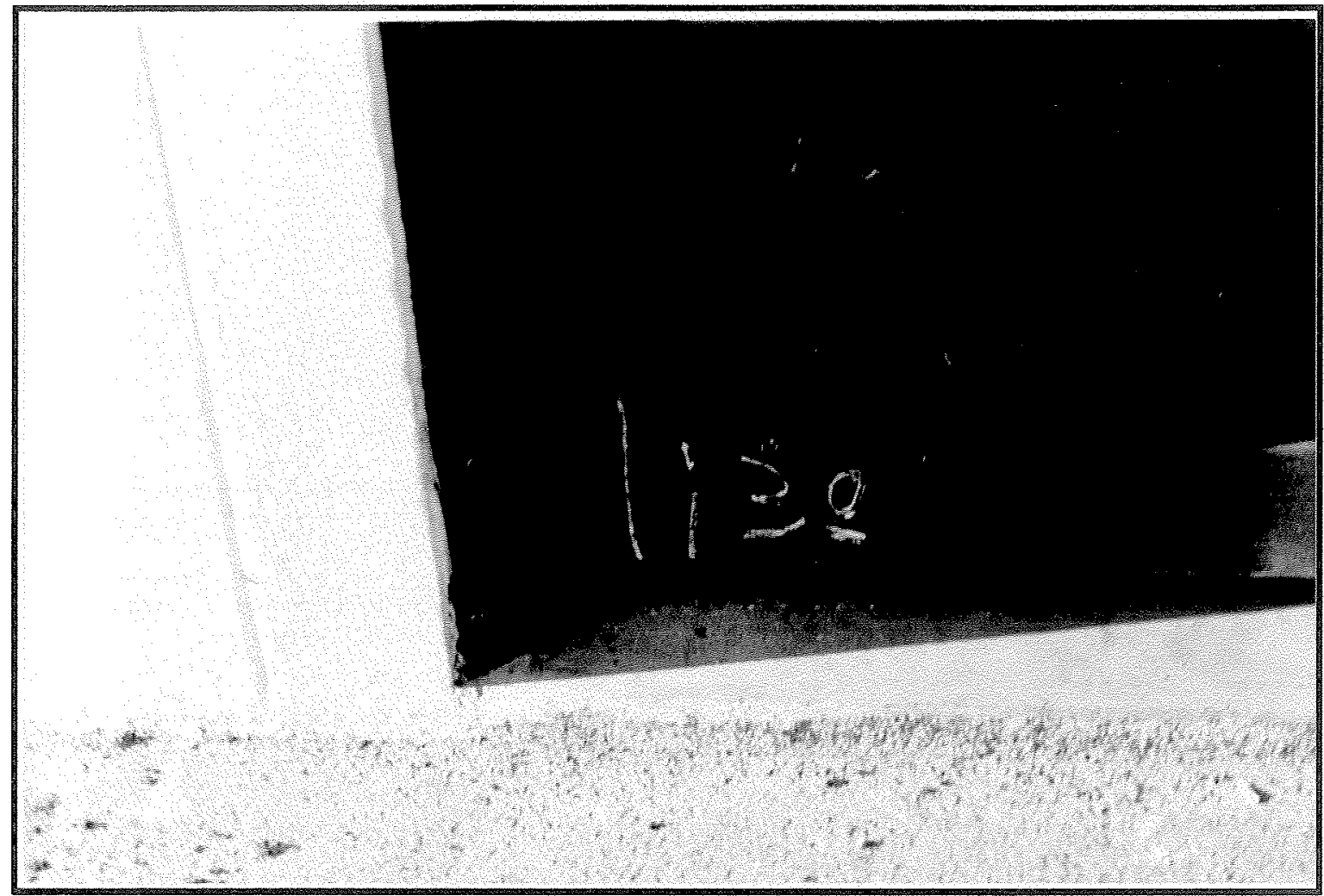

Figura 33 - Sistema construtivo I. Detalhe da ruptura da solda no canto inferior da folha.

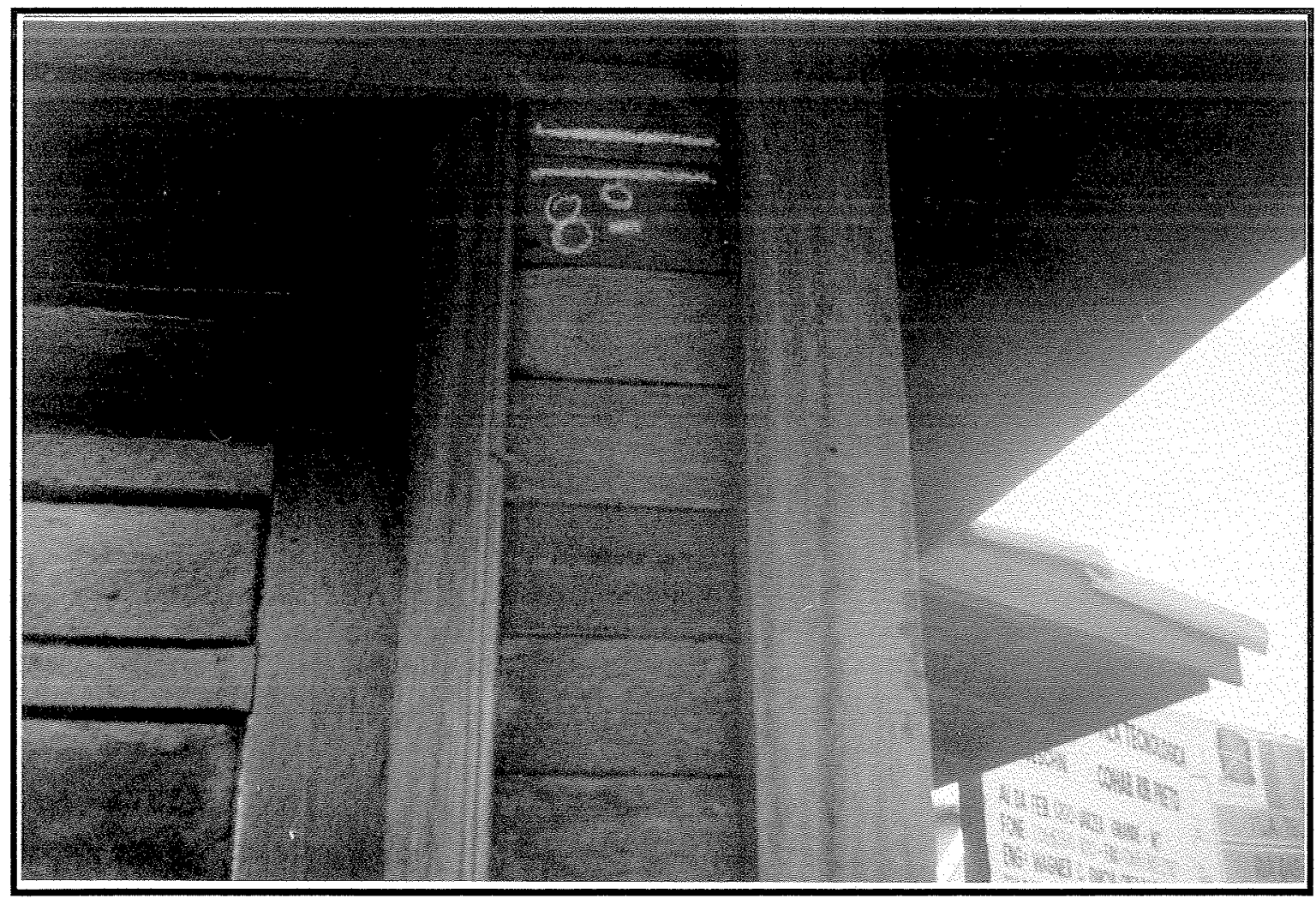

Figura 34 - Sistema construtivo $\mathrm{H}$. Detalhe da fissura na prancha durante o $8^{\circ}$ fechamento brusco. 


\subsection{Avaliação dos sistemas construtivos}

\subsubsection{Ensaio de verificação do comportamento sob ação de impactos de corpo mole de grande dimensão}

$\mathrm{Na}$ avaliação relativa ao ensaio de impactos de corpo mole de grande dimensão foram levados em consideração os critérios admitidos pelo IPT e os valores de referência do sistema construtivo convencional "padrão COHAB", como pode ser visto nas figuras 35 e 36 .

Os sistemas construtivos $\mathrm{E}, \mathrm{F}$ e $\mathrm{J}$ não apresentaram nenhuma ocorrência nos impactos de 120 a 960J. As deformaçōes instantâneas e residuais apresentaram valores menores que $\circ$ padrão de referência COHAB, sendo então avaliados como satisfatórios.

Apesar do sistema construtivo $\mathbf{G}$ näo ter apresentado nenhuma ocorrência durante os impactos, os resultados tanto da deformação instantânea como residual mantiveram-se entre o limite admitido pelo critério e o padrão $\mathrm{COHAB}$, portanto foi avaliado como regular.

Observou-se que na deformação instantânea, o sistema construtivo C, foi considerado insatisfatório em relação ao padrão COHAB mas, não foram constatados valores significativos na deformação residual. Provavelmente, isto ocorreu, devido ao comportamento elástico do painel (grandes deslocamentos sem deformações residuais consideráveis). Nos impactos de 720 e 960J não houve ruína do elemento ensaiado, e nos demais impactos registrou-se uma pequena fissura na junta direita do painel. Levando-se em consideração as ocorrências e deformações encontradas o sistema construtivo $\mathrm{C}$, foi considerado regular em relação ao padrão COHAB.

$\mathrm{Na}$ deformação instantânea, os sistemas construtivos $\mathrm{D}$ e I foram considerados regulares mas, não foram registradas deformações residuais 
no $3^{\circ}$ impacto de 240J. Ambos apresentaram pequenas fissuras durante os impactos de 120, 240, 360 e 480J mas, não houve ruína nos impactos de 720 e 960J. Os sistemas construtivos D e I foram avaliados como regulares em confronto com o padrão de referência adotado.

Não foi observada nenhuma ocorrência no sistema construtivo $B$ e a deformação instantânea registrada no $1^{\circ}$ impacto de 240J estava abaixo do limite padrão $\mathrm{COHAB}$. Também não foram constatados valores significativos na deformação residual, apesar de seus valores serem maiores que o padrão de referência adotado. $\mathrm{O}$ sistema construtivo portanto foi avaliado como satisfatório.

Os sistemas construtivos $\mathrm{H}$ e $\mathrm{K}$ apesar de não apresentarem deformaçöes residuais após $\circ 3^{\circ}$ impacto de $240 \mathrm{~J}$ foram considerados insatisfatórios em relação ao padrão $\mathrm{COHAB}$, pois atingiram a ruína com energia de impacto de $960 \mathrm{~J}$ e $720 \mathrm{~J}$ respectivamente. 
Tabela 05 - Ensaio de impactos de corpo mole $240 \mathrm{~J} \mathrm{-} 1^{\circ}$ impacto

\begin{tabular}{cccrr}
\hline $\begin{array}{c}\text { Sistemas } \\
\text { construtivos }\end{array}$ & $\begin{array}{c}\text { altura da } \\
\text { parede }(\mathrm{m})\end{array}$ & $\begin{array}{c}\text { dhmáx. } \\
\mathrm{h} / 250(\mathrm{~mm})\end{array}$ & $\begin{array}{c}\text { dh } \\
(\mathrm{mm})\end{array}$ & $\begin{array}{r}\text { 1-(dhmáx.-dh) } \\
\text { phmáx. }\end{array}$ \\
\hline padrăo CoHAB & 2,84 & 11,40 & 1,70 & 14,90 \\
B & 2,57 & 10,30 & 0,50 & 4,90 \\
C & 2,73 & 11,00 & 13,00 & 119,30 \\
D & 2,50 & 10,00 & 7,10 & 71,00 \\
E & 2,50 & 10,00 & 0,00 & 0,00 \\
F & 2,71 & 11,00 & 1,10 & 10,20 \\
G & 2,88 & 11,50 & 3,00 & 26,10 \\
H & 3,00 & 12,00 & 32,50 & 270,80 \\
I & 2,50 & 10,00 & 1,80 & 18,00 \\
J & 2,80 & 11,20 & 0,40 & 3,60 \\
K & 2,68 & 11,00 & 5,80 & 54,20 \\
\hline
\end{tabular}

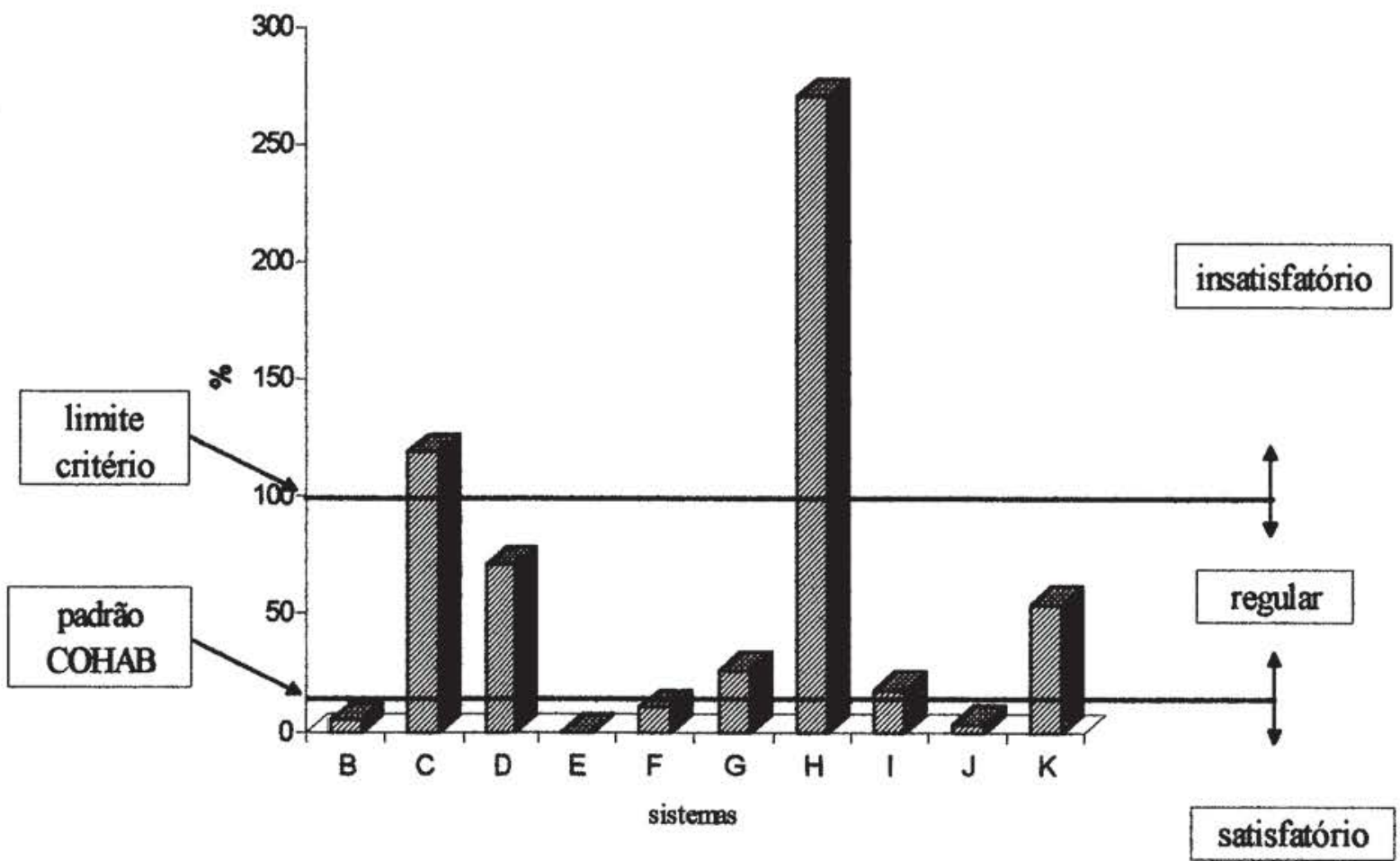

- 1-(chmáx. - ch) / dhmáx.

Figura 35 - Avaliaçăo dos sistemas em relação ao padrão COHAB. Ensaio de impactos de corpo mole de grande dimensão - $1^{\circ}$ impacto de $240 \mathrm{~J}$. 
Tabela 06 - Ensaio de impactos de corpo mole $240 \mathrm{~J}-3^{\circ}$ impacto

\begin{tabular}{ccccc}
\hline $\begin{array}{c}\text { Sistemas } \\
\text { construtivos }\end{array}$ & $\begin{array}{c}\text { altura da } \\
\text { parede }(\mathrm{m})\end{array}$ & $\begin{array}{c}\text { dhrmáx. } \\
\text { h/1250 }(\mathrm{mm})\end{array}$ & $\begin{array}{c}\text { dhr } \\
(\mathrm{mm})\end{array}$ & $\begin{array}{c}\text { 1-(dhrmáx.-dhr) }(\%) \\
\text { dhrmáx. }\end{array}$ \\
\hline padrå̃o COHAB & 2,84 & 2,30 & 0,00 & 0,00 \\
B & 2,57 & 2,10 & 0,10 & 4,80 \\
C & 2,73 & 2,20 & 0,10 & 4,50 \\
D & 2,50 & 2,00 & 0,00 & 0,00 \\
E & 2,50 & 2,00 & 0,00 & 0,00 \\
F & 2,71 & 2,20 & 0,00 & 0,00 \\
G & 2,88 & 2,30 & 0,10 & 4,30 \\
H & 3,00 & 2,40 & 0,00 & 0,00 \\
I & 2,50 & 2,00 & 0,00 & 0,00 \\
J & 2,80 & 2,20 & 0,00 & 0,00 \\
K & 2,68 & 2,10 & 0,00 & 0,00 \\
\hline
\end{tabular}

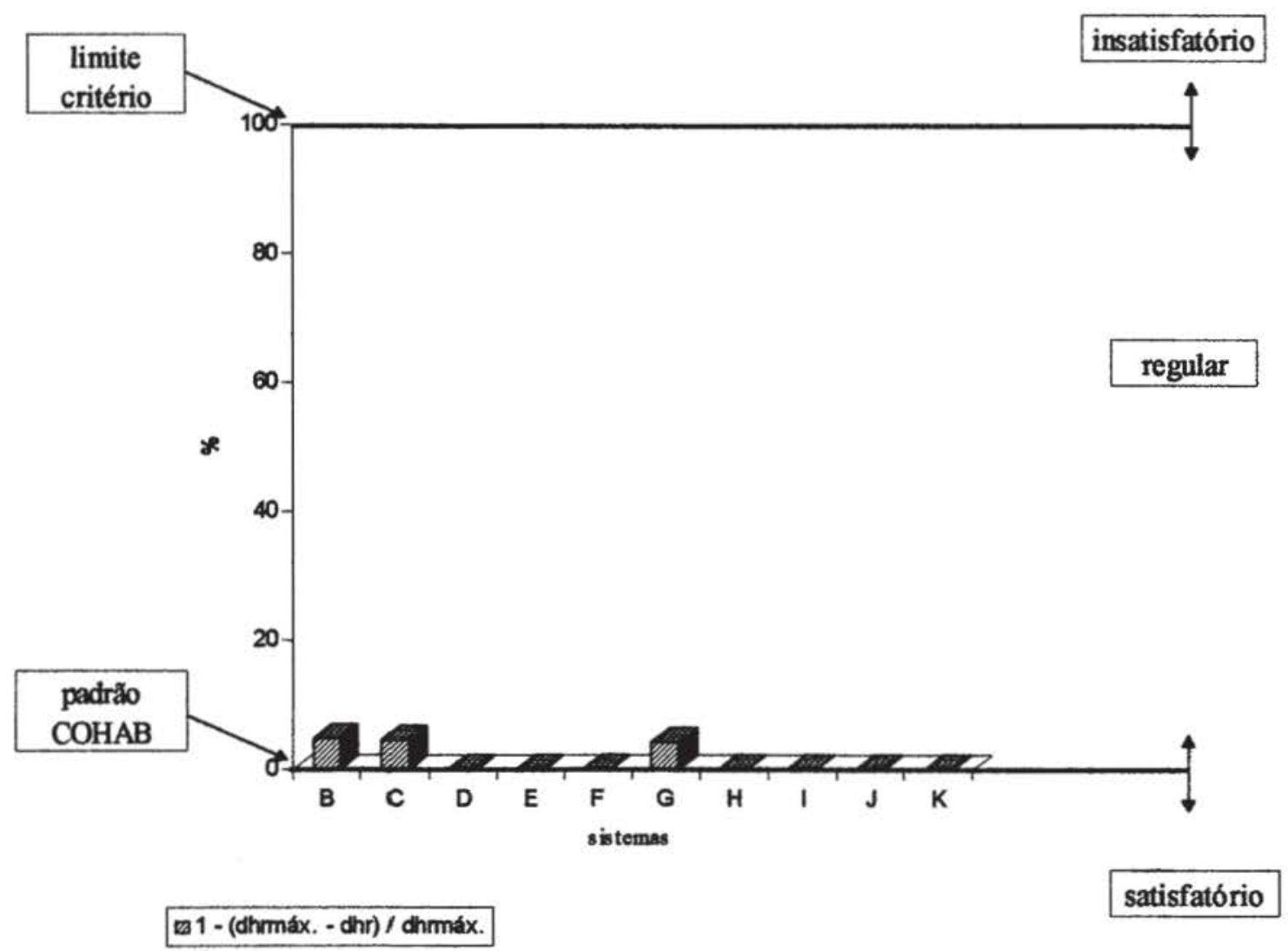

Figura 36 - Avaliação dos sistemas em relação ao padrão COHAB. Ensaio de impactos de corpo mole de grande dimensão - $3^{\circ}$ impacto de $240 \mathrm{~J}$. 


\subsubsection{Ensaio de verificação do comportamento sob ação de impactos de corpo duro de pequena e grande dimensão}

No ensaio de corpo duro de pequena e grande dimensão, no que se refere à não ocorrência de ruptura ou transpassamento, para impactos de 20J, o critério de desempenho foi totalmente cumprido pelos sistemas construtivos avaliados pois, não foram registradas ocorrências de qualquer natureza, iguais, portanto, ao padrão COHAB.

Já nos impactos de $3,75 \mathrm{~J}$, as ocorrências observadas nos sistemas construtivos $\mathrm{A}$ e $\mathrm{H}$ foram consideradas de pequena monta.

A profundidade das mossas, em todos os sistemas mantiveram-se dentro do limite de referência padrão $\mathrm{COHAB}$, como pode ser visto na figura 37.

Apenas o sistema $\mathrm{J}$ apresentou resultado superior ao limite permitido mas, como já justificado, este acontecimento se deve mais ao engrossamento do revestimento da parede, acarretado mais por falhas na colocação dos blocos, do que à resistência da parede, sendo então avaliado como regular.

Os demais sistemas construtivos analisados, de maneira geral, tiveram um comportamento satisfatório pois, seus resultados não ultrapassaram o limite obtido no "padrão COHAB". 
Tabela 07 - Ensaio de impactos de corpo duro

\begin{tabular}{ccccc}
\hline $\begin{array}{c}\text { Sistemas } \\
\text { construtivos }\end{array}$ & $\begin{array}{c}\text { altura da } \\
\text { parede }(\mathrm{m})\end{array}$ & $\begin{array}{c}\text { dmáx. } \\
(\mathrm{mm})\end{array}$ & $\begin{array}{c}\mathrm{d} \\
(\mathrm{mm})\end{array}$ & $\begin{array}{c}\text { 1-(dmáx.-d) } \\
\text { dmáx. }\end{array}$ \\
\hline Padrắ COHAB & 2,84 & 2,00 & 1,00 & 50,00 \\
B & 2,57 & 2,00 & 0,00 & 0,00 \\
C & 2,73 & 2,00 & 0,00 & 0,00 \\
D & 2,50 & 2,00 & 1,00 & 50,00 \\
E & 2,50 & 2,00 & 0,50 & 25,00 \\
F & 2,71 & 2,00 & 1,00 & 50,00 \\
G & 2,88 & 2,00 & 0,90 & 45,00 \\
H & 3,00 & 2,00 & 0,00 & 0,00 \\
I & 2,50 & 2,00 & 0,50 & 25,00 \\
J & 2,80 & 2,00 & 3,40 & 170,00 \\
K & 2,68 & 2,00 & 0,00 & 0,00 \\
\hline
\end{tabular}

$\mathrm{d}=$ profundidade da mossa

dmáx. = máximo admitido pelo critério

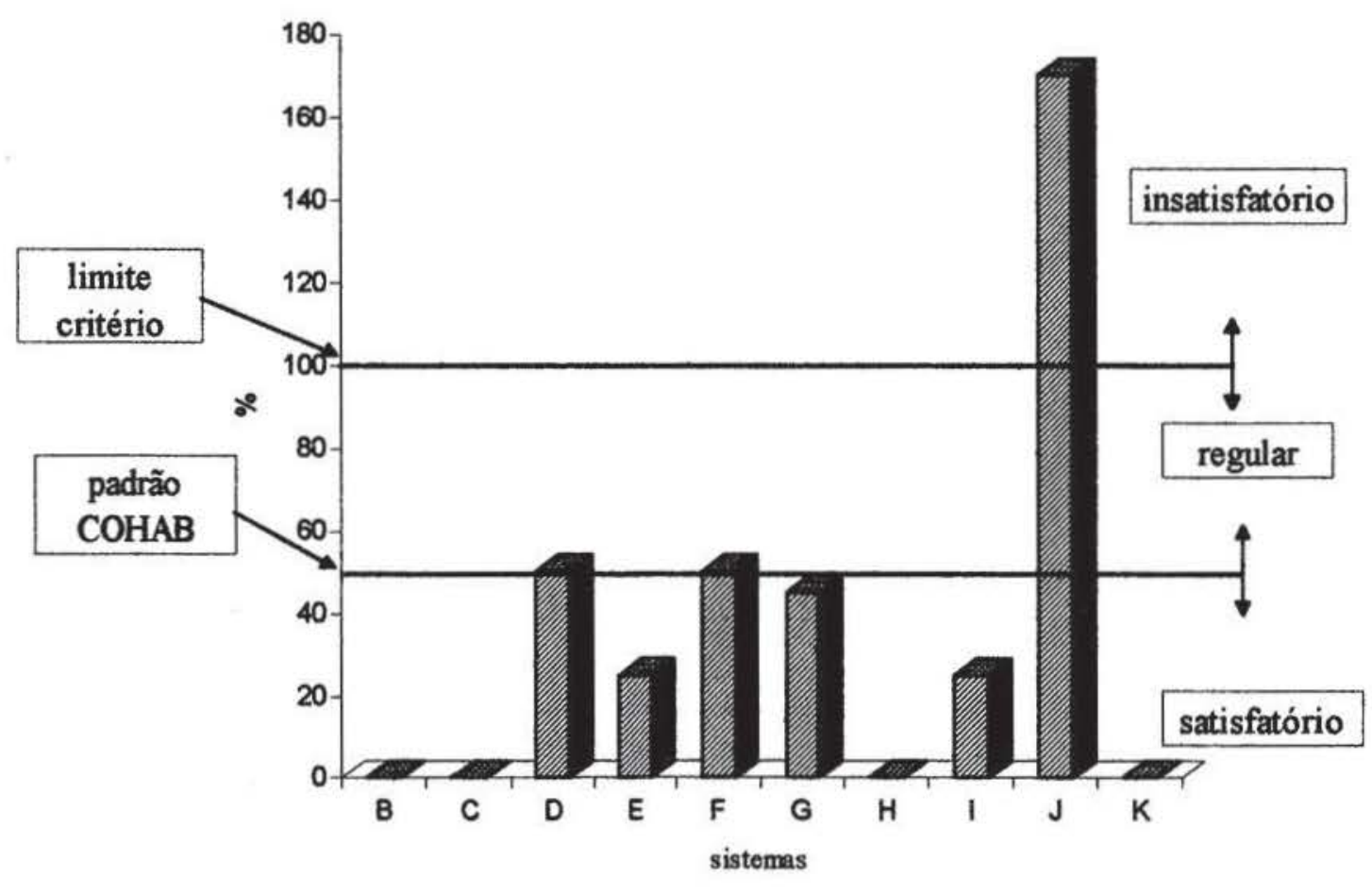

圆 1 - (dmáx.-d) / dmáx.

Figura 37 - Avaliação dos sistemas em relação ao padrăo COHAB. Ensaio de impactos de corpo duro de pequena dimensão. 


\subsubsection{Ensaio de verificação do comportamento sob ação de cargas provenientes de peças suspensas}

Para avaliação dos sistemas construtivos em relação às solicitações de cargas provenientes de peças suspensas, levou-se em consideração as deformações instantâneas e residuais (figuras 38 e 39), as ocorrências registradas no elemento ensaiado após 24 horas de carregamento e os resultados obtidos no padrão de referência $\mathrm{COHAB}$.

Os valores das deformações instantâneas e residuais mantiveram-se abaixo dos valores de referência padrão $\mathrm{COHAB}$, nos sistemas construtivos F, J e K. Não foram constatadas ocorrências. Logo, estes sistemas construtivos foram avaliados como satisfatórios em relação ao padrão de referência adotado.

Os sistemas construtivos $\mathrm{C}, \mathrm{D}, \mathrm{E}, \mathrm{G}$ e I não apresentaram qualquer tipo de ocorrência e as deformações instantâneas e residuais tiveram valores entre o limite admitido pelo critério e o padrão $\mathrm{COHAB}$, sendo então avaliados como regulares.

Apesar de apresentar deformações instantâneas e residuais abaixo do limite do critério, o sistema construtivo $\mathrm{H}$, apresentou após 24 horas de manutenção do carregamento, empenamento das tábuas que sustentavam o dispositivo da carga. Logo, o sistema construtivo $\mathrm{H}$ foi considerado insatisfatório em relação ao padrão $\mathrm{COHAB}$.

Não foi possivel, a avaliação do sistema construtivo $B$ em relação a cargas provenientes de peças suspensas pois, o ensaio foi prejudicado por operários que trabalhavam no local. 
Tabela 08 - Ensaio de peças suspensas - deformaçōes instantâneas

\begin{tabular}{ccccc}
\hline $\begin{array}{c}\text { Sistemas } \\
\text { construtivos }\end{array}$ & $\begin{array}{c}\text { altura da } \\
\text { parede }(\mathrm{m})\end{array}$ & $\begin{array}{c}\text { dhmáx. } \\
(\mathrm{mm})\end{array}$ & $\begin{array}{c}\mathrm{dh} \\
(\mathrm{mm})\end{array}$ & $\begin{array}{c}\text { 1-(dhmáx.-dh) } \\
\text { phmáx. }\end{array}$ \\
\hline padrăo COHAB & 2,84 & 5,70 & 0,14 & 2,50 \\
B & 2,57 & 5,14 & $*$ & $*$ \\
C & 2,73 & 5,46 & 0,33 & 6,00 \\
D & 2,50 & 5,00 & 0,75 & 10,60 \\
E & 2,50 & 5,00 & 0,21 & 4,20 \\
F & 2,71 & 5,42 & 0,03 & 0,60 \\
G & 2,88 & 5,76 & 0,70 & 12,20 \\
H & 3,00 & 6,00 & 3,43 & 57,20 \\
I & 2,50 & 5,00 & 1,01 & 20,20 \\
J & 2,80 & 5,60 & 0,03 & 0,50 \\
K & 2,68 & 5,40 & 0,10 & 1,90 \\
\hline
\end{tabular}

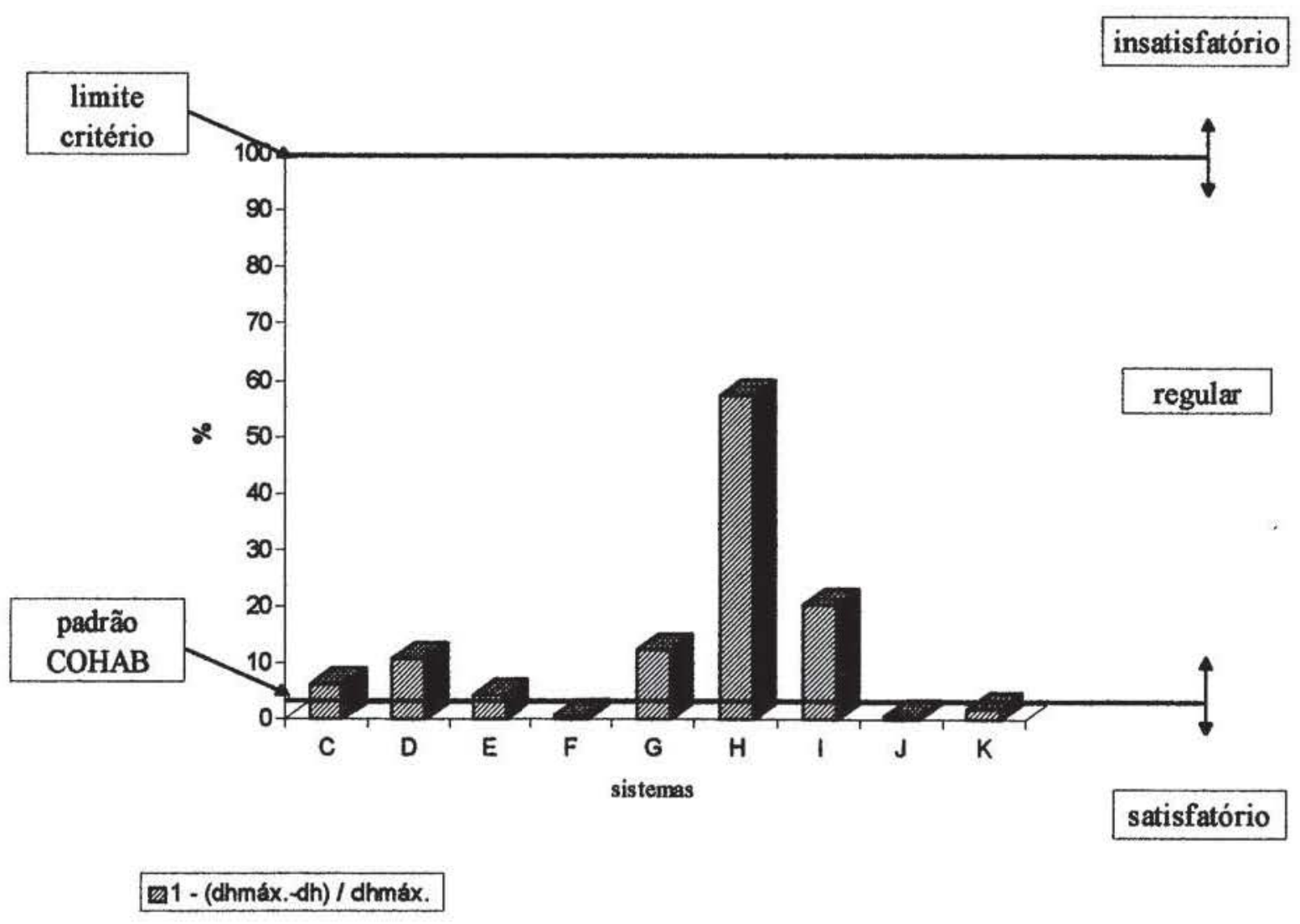

Figura 38 - Avaliaçăo dos sistemas em relação ao padrão COHAB. Ensaio de cargas provenientes peças suspensas - deformaçőes instantåneas. 
Tabela 09 - Ensaio de peças suspensas - deformaçőes residuais

\begin{tabular}{ccccc}
\hline $\begin{array}{c}\text { Sistemas } \\
\text { construtivos }\end{array}$ & $\begin{array}{c}\text { altura da } \\
\text { parede }(\mathrm{m})\end{array}$ & $\begin{array}{c}\text { dhrmáx. } \\
(\mathrm{mm})\end{array}$ & $\begin{array}{c}\text { Dhr } \\
(\mathrm{mm})\end{array}$ & $\begin{array}{c}1 \text {-(dhrmáx.-dhr) }(\%) \\
\text { dhrmáx. }\end{array}$ \\
\hline padrão COHAB & 2,84 & 1,10 & 0,13 & 11,82 \\
B & 2,57 & 1,03 & $*$ & $*$ \\
C & 2,73 & 1,10 & 0,21 & 19,09 \\
D & 2,50 & 1,00 & 0,53 & 29,00 \\
E & 2,50 & 1,00 & 0,13 & 13,00 \\
F & 2,71 & 1,10 & 0,03 & 2,73 \\
G & 2,88 & 1,20 & 0,70 & 58,33 \\
H & 3,00 & 1,20 & 1,03 & 85,82 \\
I & 2,50 & 1,00 & 1,00 & 100,00 \\
J & 2,80 & 1,10 & 0,02 & 1,82 \\
K & 2,68 & 1,10 & 0,05 & 4,55 \\
\hline
\end{tabular}

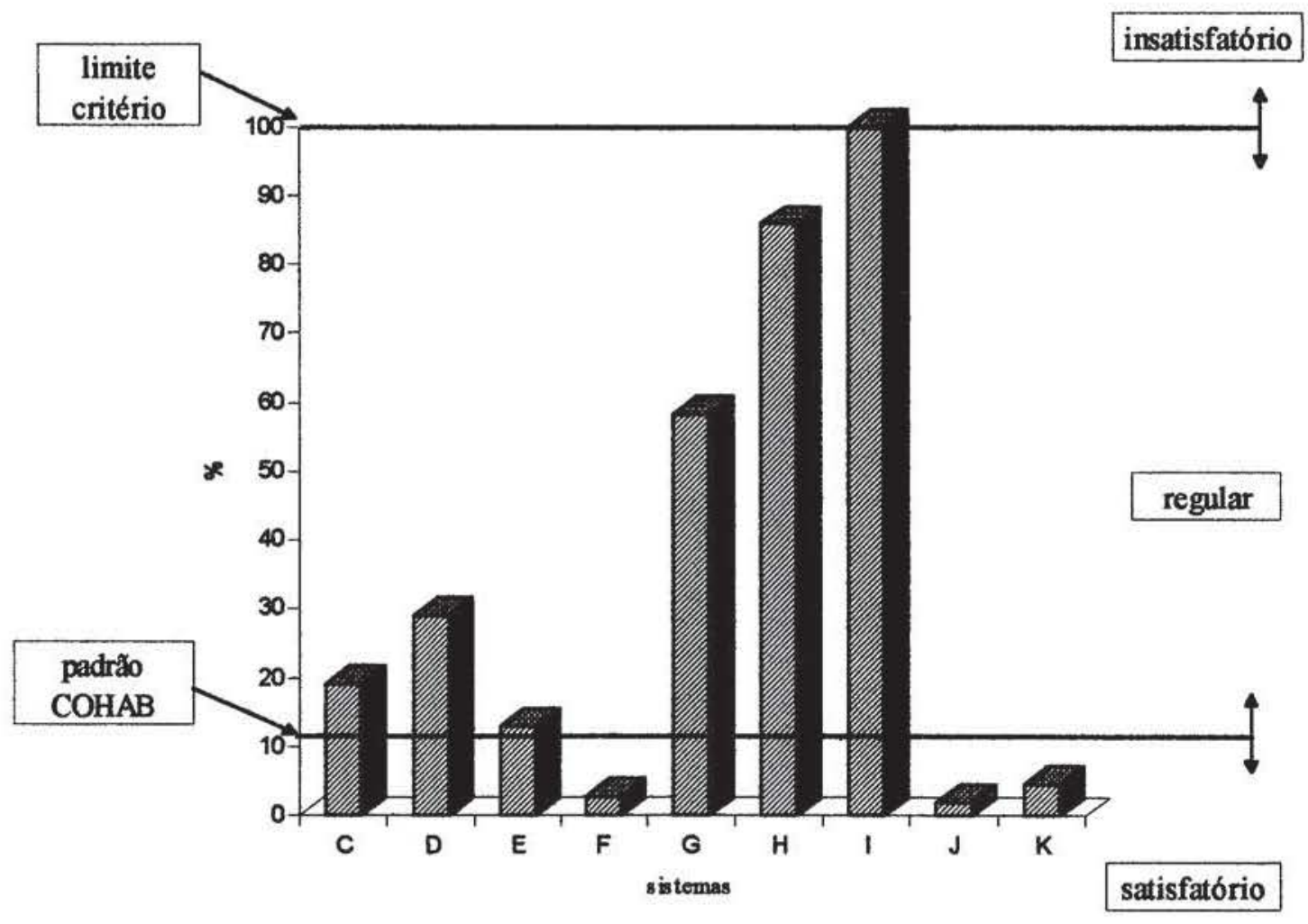

ש1 - (dhrmáx.-dhr) / dhrmax.

Figura 39 - Avaliação dos sistemas em relação ao padrão COHAB. Ensaio de cargas provenientes de peças suspensas - deformações residuais. 


\subsubsection{Ensaio de verificação do comportamento sob ação de fechamentos bruscos de portas}

No ensaio de fechamento brusco (tabela 10), a avaliação foi feita considerando o critério estabelecido (não ocorrência de rupturas, fissuraçöes, destacamentos ou cisalhamento no contorno do marco) e as ocorrências registradas na casa padrão $\mathrm{COHAB}$.

Os sistemas construtivos avaliados como regulares em relação ao padrão $\mathrm{COHAB}$ foram aqueles que apresentaram pequenas fissuras no contorno do batente e/ou desprendimento do revestimento, como os sistemas construtivos $\mathrm{B}, \mathrm{C}, \mathrm{E}, \mathrm{J}$ e K.

Não foram registradas ocorrências nas paredes externas analisadas dos sistemas construtivos $\mathrm{D}$ e I, sendo portanto avaliados como satisfatórios em confronto com o padrão de referência adotado.

$\mathrm{O}$ sistema construtivo $\mathrm{H}$ foi considerado insatisfatório em relação ao padrão adotado por apresentar diminuição na rigidez do conjunto painel/porta.

Como já registrado, observou-se uma certa fragilidade das folhas das portas empregadas nos sistemas construtivos analisados, o que influenciou na avaliação relativa ao ensaio pois, os sistema construtivos $F$ e $G$ foram considerados insatisfatórios em relação ao padrão $\mathrm{COHAB}$ pelo encerramento do ensaio no $7^{\circ}$ fechamento brusco devido à danos na porta, sem ter-se registrado até então, quaisquer ocorrências nas paredes. É sugerido então, mudanças nos procedimentos do ensaio relatadas a seguir no sub-capítulo 5.4 . 
Tabela 10 - Avaliação dos sistemas em relação ao padrão COHAB - ensaio de fechamento brusco de portas

\begin{tabular}{|c|c|c|}
\hline Sistemas construtivos & Ocorrências & Avaliação \\
\hline padrão $\mathrm{COHAB}$ & danos na fechadura; funcionabilidade da chave prejudicada; sem danos à parede & satisfatório \\
\hline B & $\begin{array}{l}\text { pequena fissura no contorno do batente na parte superior direita, face interna e no } \\
\text { rejuntamento do revestimento externo }\end{array}$ & regular \\
\hline C & $\begin{array}{l}\text { pequena fissura vertical na junção painel/marco, lado esquerdo face interna da } \\
\text { parede }\end{array}$ & regular \\
\hline D & afundamento da porta na região da fechadura; sem danos à parede & satisfatório \\
\hline $\mathrm{F}$ & $\begin{array}{l}\text { ruptura da folha da porta; sem danos à parede; ensaio encerrado no } 7^{\circ} \text { fechamento } \\
\text { brusco }\end{array}$ & insatisfatório \\
\hline G & $\begin{array}{l}\text { ruptura da folha da porta; sem danos à parede; ensaio encerrado no } 7^{\circ} \text { fechamento } \\
\text { brusco }\end{array}$ & insatisfatório \\
\hline $\mathrm{H}$ & $\begin{array}{l}\text { lascamento da guarnição superior do batente; diminuição da rigidez do conjunto } \\
\text { painel/porta }\end{array}$ & insatisfatório \\
\hline $\mathrm{K}$ & $\begin{array}{l}\text { ruptura da solda entre o montante da porta e o perfil de sustentação do vidro na } \\
\text { região da fechadura; funcionabilidade da fechadura prejudicada; sem danos à parede }\end{array}$ & regular \\
\hline
\end{tabular}




\begin{tabular}{|c|c|c|c|c|c|}
\hline \multicolumn{6}{|c|}{$\begin{array}{c}\text { Tabela } 11 \text { - Avaliação dos sistemas construtivos empregados na Vila Tecnológica de } \\
\text { Ribeirão Preto }\end{array}$} \\
\hline $\begin{array}{l}\text { Sistemas } \\
\text { construtivos }\end{array}$ & Corpo mole & $\begin{array}{l}\text { Corpo } \\
\text { duro }\end{array}$ & Estanqueidade & $\begin{array}{l}\text { Peças } \\
\text { suspensas }\end{array}$ & $\begin{array}{l}\text { Fechamento } \\
\text { brusco }\end{array}$ \\
\hline B & satisfatório & satisfatório & * & * & regular \\
\hline $\mathrm{C}$ & regular & satisfatório & satisfatório & regular & regular \\
\hline D & regular & satisfatório & regular & regular & satisfatório \\
\hline $\mathrm{E}$ & satisfatório & satisfatório & insatisfatório & regular & regular \\
\hline $\bar{F}$ & satisfatório & satisfatório & * & satisfatório & insatisfatório \\
\hline G & regular & satisfatório & insatisfatório & regular & insatisfatório \\
\hline $\mathrm{H}$ & insatisfatório & satisfatório & insatisfatório & insatisfatório & insatisfatório \\
\hline 1 & regular & satisfatório & insatisfatório & regular & satisfatório \\
\hline $\mathrm{J}$ & satisfatório & regular & satisfatório & satisfatório & regular \\
\hline $\mathrm{K}$ & insatisfatório & satisfatório & insatisfatório & satisfatório & regular \\
\hline
\end{tabular}

* ensaio prejudicado 


\subsection{Dificuldades encontradas e sugestões}

A avaliação dos sistemas construtivos por ensaios realizados 'in loco', permitiu constatar algumas dificuldades na execução dos mesmos, com relação à metodologia prescrita nas normas correspondentes. Tais dificuldades, sem dúvida, são devidas ao fato de que os procedimentos de ensaio são melhores adaptados ao laboratório do que ao campo.

Algumas dificuldades encontradas são descritas a seguir:

a) o procedimento do ensaio de impacto de corpo mole ou corpo duro é descrito conforme a figura 40 . Como o ensaio foi feito em campo e as unidades já estavam concluídas, o beiral existente, obrigou a sustentação do saco cilíndrico, de forma que não se alterasse a energia de impacto. A alteração procedida é mostrada na figura 41.
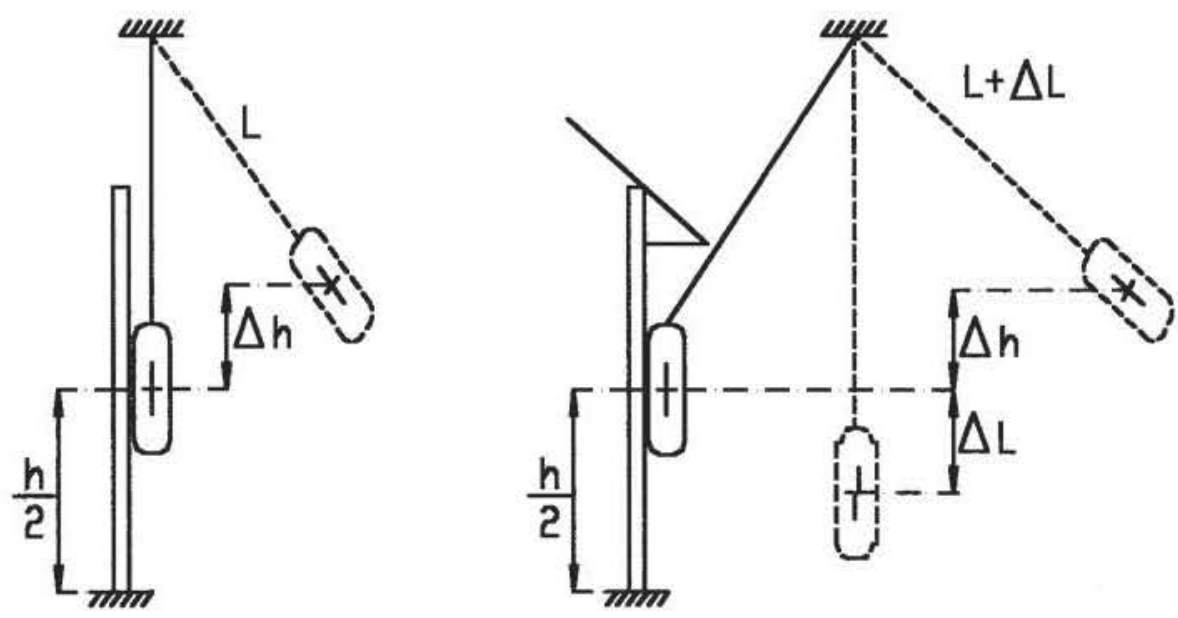

Figura 40 - Procedimento do ensaio

Figura 41- Ensaio em campo

b) outra dificuldade encontrada, foi no ensaio de peças suspensas, já que os fabricantes não especificam o tipo e o local de fixação nas paredes. Neste caso, o aparato é montado a meia altura, no centro do painel ou parede, podendo causar ocorrências não desejadas no transcorrer do ensaio. 
c) como o objetivo do ensaio de fechamento brusco era o de avaliar o comportamento de paredes quando submetidas a manobras anormais de portas, em alguns dos sistemas não foi possível o término do ensaio devido a fragilidade da folha.

\section{Sugestões:}

a) na descrição dos procedimentos de ensaio deve-se prever a utilização do equipamento em ensaios realizados em campo, considerando os beirais e piso externo, facilitando a fixação e manuseio do equipamento para os ensaios de corpo mole e corpo duro.;

b) exigir dos fabricantes maiores especificações para evitar dúvidas e ocorrências indesejáveis, durante a avaliação, garantindo assim a qualidade de seu produto;

c) definir uma porta padrão que tenha resistência suficiente para suportar os 10 fechamentos bruscos sem prejudicar o ensaio. 


\section{CONCLUSÕES}

O conceito de desempenho é aplicado em produtos para os quais não existe uma normalização técnica específica, sendo então, necessário a sua utilização para constatar se as exigências dos usuários estão sendo atendidas.

A necessidade da aplicação deste conceito cresce juntamente com a industrialização da construção civil que tenta suprir o déficit habitacional através de sistemas construtivos inovadores.

A avaliação destes sistemas construtivos carece ainda de uma metodologia que especifique os limites mínimos de qualidade a serem alcançados.

Em alguns países europeus a produção de sistemas construtivos novos, sempre foi acompanhada da avaliação de desempenho, diminuindo assim, as restrições no que se refere a introdução de construções inovadoras. Desde 1965 o CSTB (Centre Scientifique et Techinique du Bâtiment), da França, já publicava exigências a serem cumpridas por habitações leves.

No Brasil a falta de uma normalização dificulta a introdução de sistemas construtivos com qualidade, pois os fabricantes e construtores não possuem parâmetros em que se basear para garantir a qualidade do produto final, sendo então lançado no mercado tecnologias não testadas ou avaliadas.

É importante citar que, para elaboração das normas de desempenho deve-se determinar requisitos e critérios de desempenho a que um determinado produto deve atender, independentemente de sua forma e natureza. Isto porque, podem abranger vários produtos ainda não 
normalizados, o que não acontece com os códigos de obras ou as normas prescritivas. Uma mudança já verificada mas, que ainda carece de um embasamento maior de especificações é registrada no novo CÓDIGO DE OBRAS E EDIFICAÇÕES DO MUNICÍPIO DE SÃO PAULO (1992) onde relaciona, o desempenho de uma edificação, como uma das especificações a serem atendidas. É registrado no referido código: "o desempenho obtido pelo emprego de componentes, em especial daqueles ainda não consagrados pelo uso, bem como quando em utilizações diversas das habituais, será de inteira responsabilidade do Profissional que os tenha especificado ou adotado. A Prefeitura Municipal de São Paulo poderá desaconselhar o emprego de componentes considerados inadequados, que possam vir a comprometer o desempenho desejável, bem como referendar a utilização daqueles cuja qualidade seja notável".

Já a implementação de certificados de homologação para produtos novos, devem ser interpretados como uma forma de determinar a viabilidade ou não de uso do sistema inovador, pois não garantem integralmente sua qualidade e requer todo um sistema estruturado de aprovação como a UEAtc (Union Européene pour L'agreemente Techinique dans la Construction) na Europa.

Com a aplicação prática deste estudo, concluiu-se que os programas que surgem tentando resolver o déficit habitacional no país, incentivando as soluções inovadoras com objetivo de construir-se mais, gastando-se menos sem prejudicar a qualidade do produto, devem estar acompanhados de um projeto de avaliação para constatar a qualidade dos sistemas construtivos, pois assim, evitariam a construção de habitações que não satisfazem as exigências dos usuários.

A falta de maiores informações sobre o produto, através de projetos e especificaçōes técnicas necessárias, por partes dos fabricantes ocasiona dúvidas e ocorrências não previstas, tanto na avaliação, quanto durante a ocupação da habitação pelos usuários. Fato este evidenciado durante o ensaio de cargas provenientes de peças suspensas, pois não constava nas 
especificações o sistema de fixaçăo adequado para cada tecnologia, nem o local destinado à elas.

É relevante citar, a importância da avaliação de desempenho de novas tecnologias para habitação antes de entrarem no mercado. Isto porque, os sistemas construtivos que obtiveram avaliação insatisfatória, foram justamente os que não apresentaram, no processo licitatório da Vila Tecnológica, resultados de ensaios realizados em laboratório.

Vale lembrar que, apesar de alguns sistemas construtivos necessitarem de melhorias para alcançar os valores mínimos de qualidade adotados neste trabalho, os mesmos são considerados satisfatórios pelos critérios de desempenho.

Com os resultados obtidos na avaliação proposta pode-se verificar que as tecnologias avaliadas no conjunto, apresentaram um bom resultado no contexto geral de cada ensaio, como pode ser visto a seguir:

Tabela 12 - Porcentagem dos níveis de qualidade em relaçăo aos ensaios realizados

\begin{tabular}{lcccc}
\hline & $\begin{array}{c}\text { Impactos de } \\
\text { corpo mole }\end{array}$ & $\begin{array}{c}\text { Impactos de } \\
\text { corpo duro }\end{array}$ & $\begin{array}{c}\text { Peças } \\
\text { suspensas }\end{array}$ & $\begin{array}{c}\text { Fechamento } \\
\text { brusco }\end{array}$ \\
\hline Satisfatório & $40 \%$ & $90 \%$ & $30 \%$ & $20 \%$ \\
Regular & $40 \%$ & $10 \%$ & $50 \%$ & $50 \%$ \\
Insatisfatório & $20 \%$ & $0 \%$ & $10 \%$ & $30 \%$ \\
\hline
\end{tabular}

* ensaio prejudicado

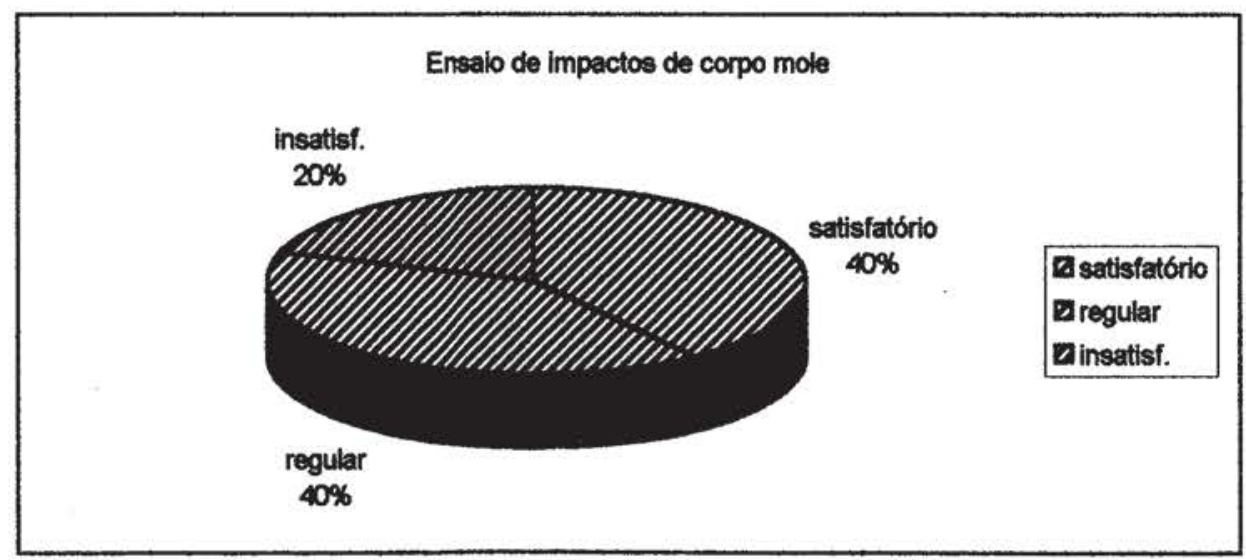

Figura 42 - Porcentagem dos níveis de qualidade em relação ao ensaio de impactos de corpo mole de grande dimensão 


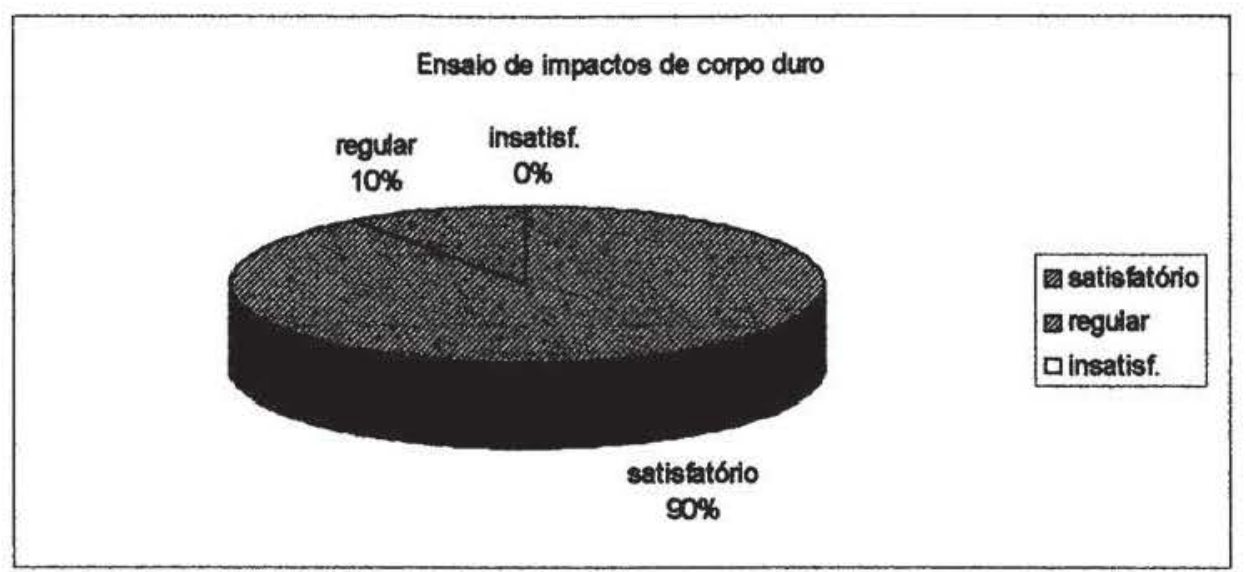

Figura 43 - Porcentagem dos níveis de qualidade em relação ao ensaio de impactos de corpo duro de pequena e grande dimensăo.

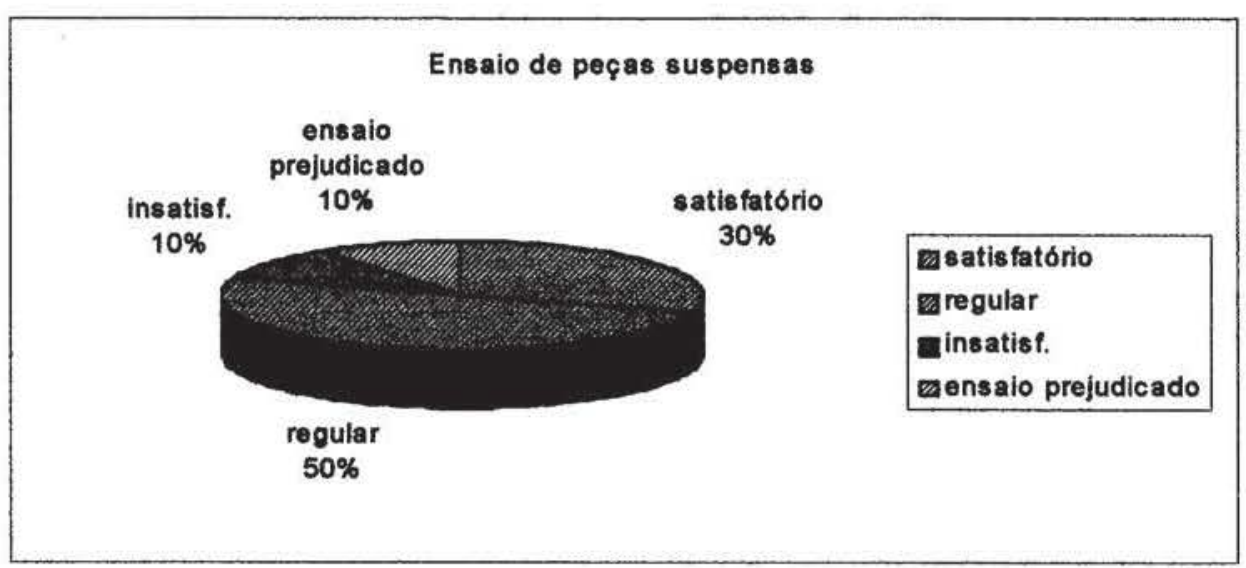

Figura 44 - Porcentagem dos níveis de qualidade em relação ao ensaio de cargas provenientes de peças suspensas.

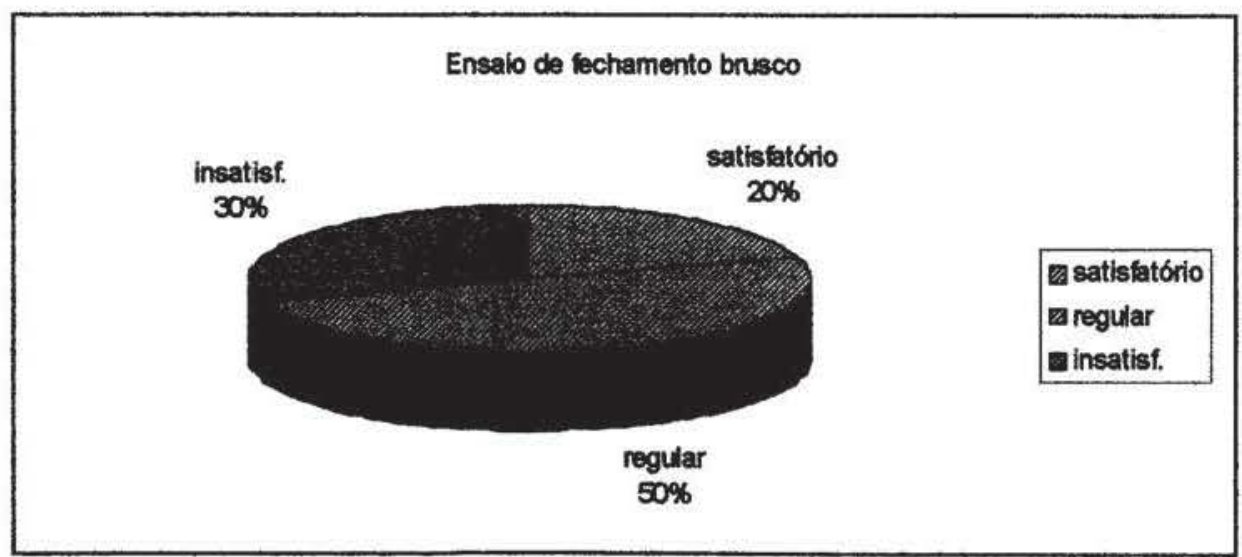

Figura 45 - Porcentagem dos níveis de qualidade em relação ao ensaio de fechamento brusco de portas. 
A avaliação estrutural realizada na Vila Tecnológica de Ribeirão Preto, proporcionou bases racionais à identificação de falhas dos sistemas construtivos nela empregados. Por isso, esta avaliação foi considerada um fator relevante na identificação de determinados aspectos que devem ser modificados de forma a proporcionar ao sistema construtivo um desempenho satisfatório.

Vale ressaltar que, a avaliação de um sistema inovador não se restringe apenas à segurança estrutural . Existem outras exigências a serem levadas em consideração para avaliação total de um sistema inovador, como por exemplo, conforto térmico, conforto acústico, estanqueidade à água e etc. Mas, tal avaliação é fator essencial para garantir a durabilidade do produto e segurança do usuário. Sugere-se então, que na avaliação geral de uma nova tecnologia, o desempenho estrutural, seja fator relevante para aprovação do produto.

Espera-se então que a avaliação proposta, possa contribuir para futuras avaliações, além de fornecer aos fabricantes subsídios para melhoria da qualidade de novas tecnologias a serem lançadas no mercado. 
ANEXOS

Localização dos ensaios nos sistemas construtivos. 
A) Sistema construtivo convencional - padrão COHAB

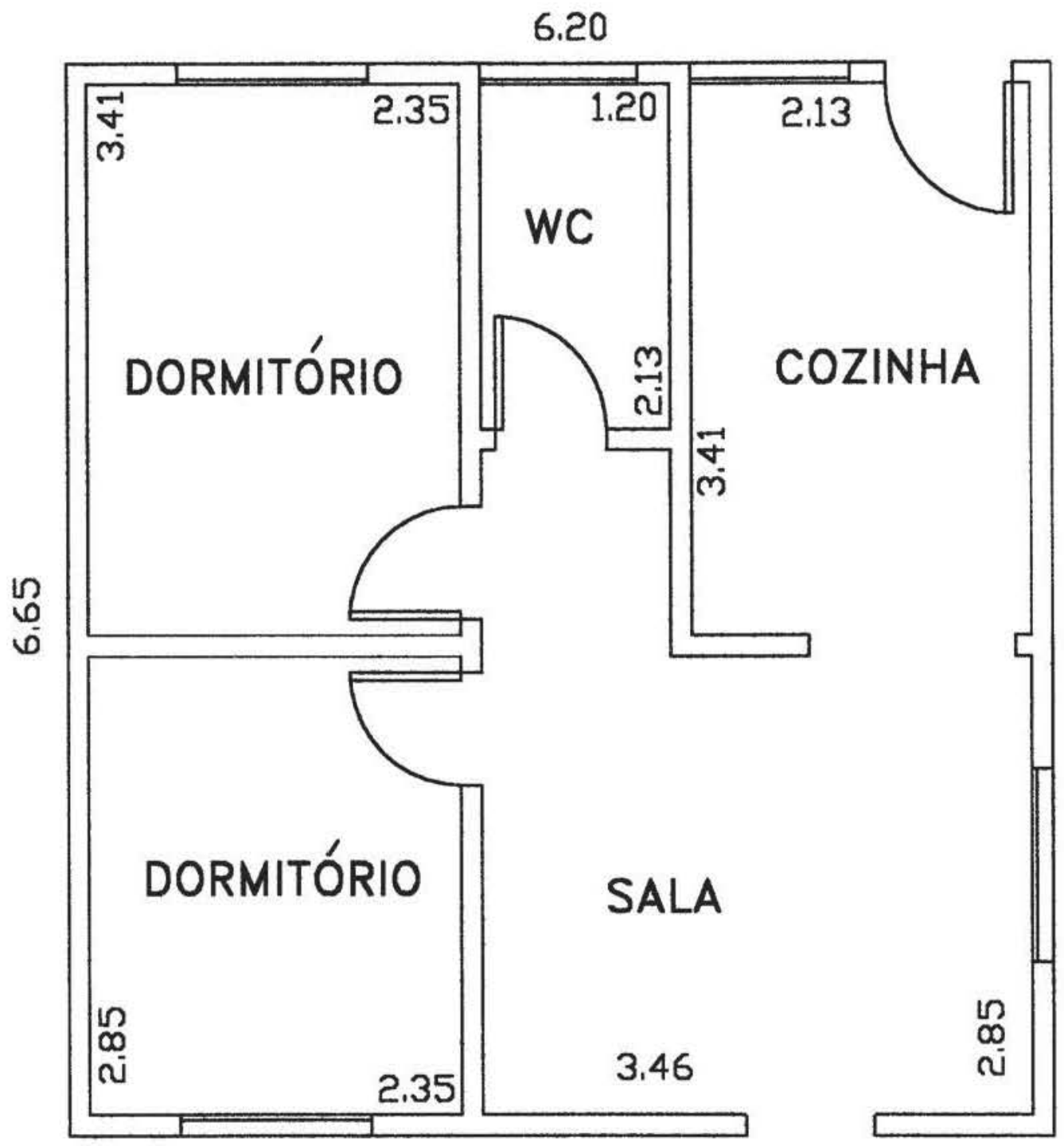

peços suspensas

Impacto de corpo duro
Impacto de corpo mole

fechamento brusco de portes

escala 1:50 
B) Sistema construtivo B

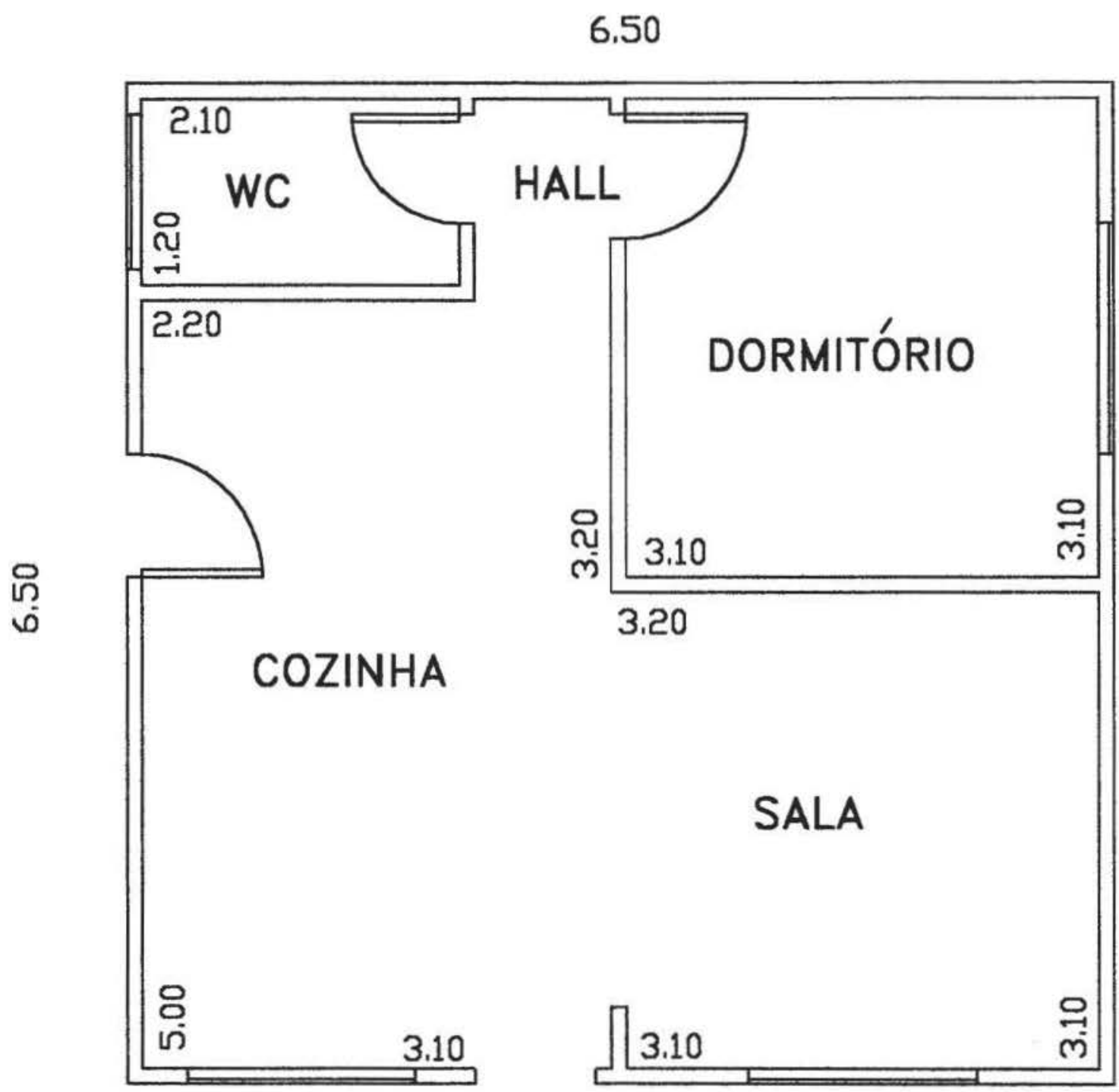

peças suspensas

Impacto de corpo mole

Impacto de corpo duro

fechamento brusco de portas

escala 1:50 
C) Sistema construtivo C

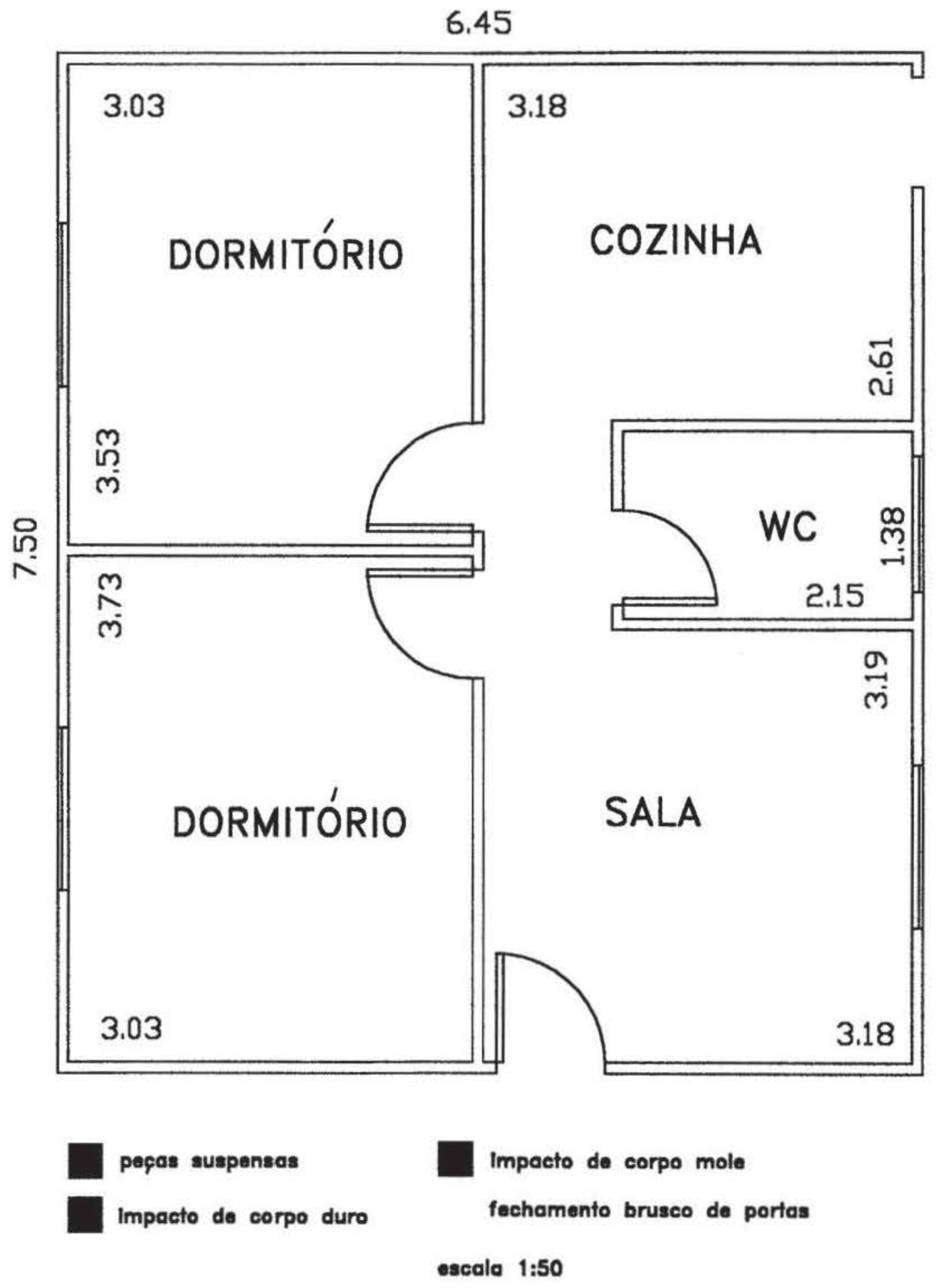


D) Sistema construtivo D

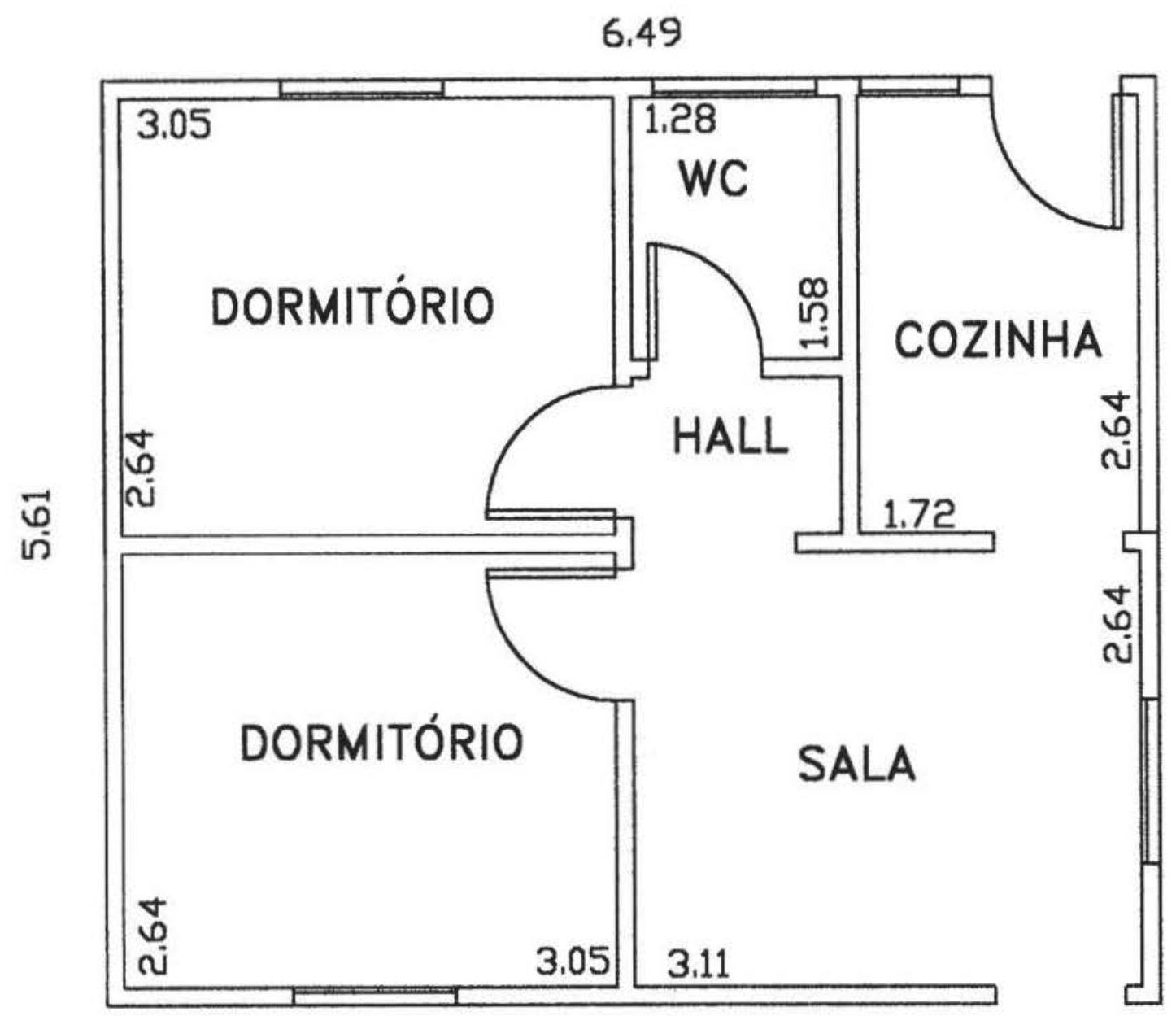

peça suspensas

Impacto de corpo duro
Impacto de corpo mole

fechamento brusco de portas

escala 1:50 
E) Sistema construtivo E

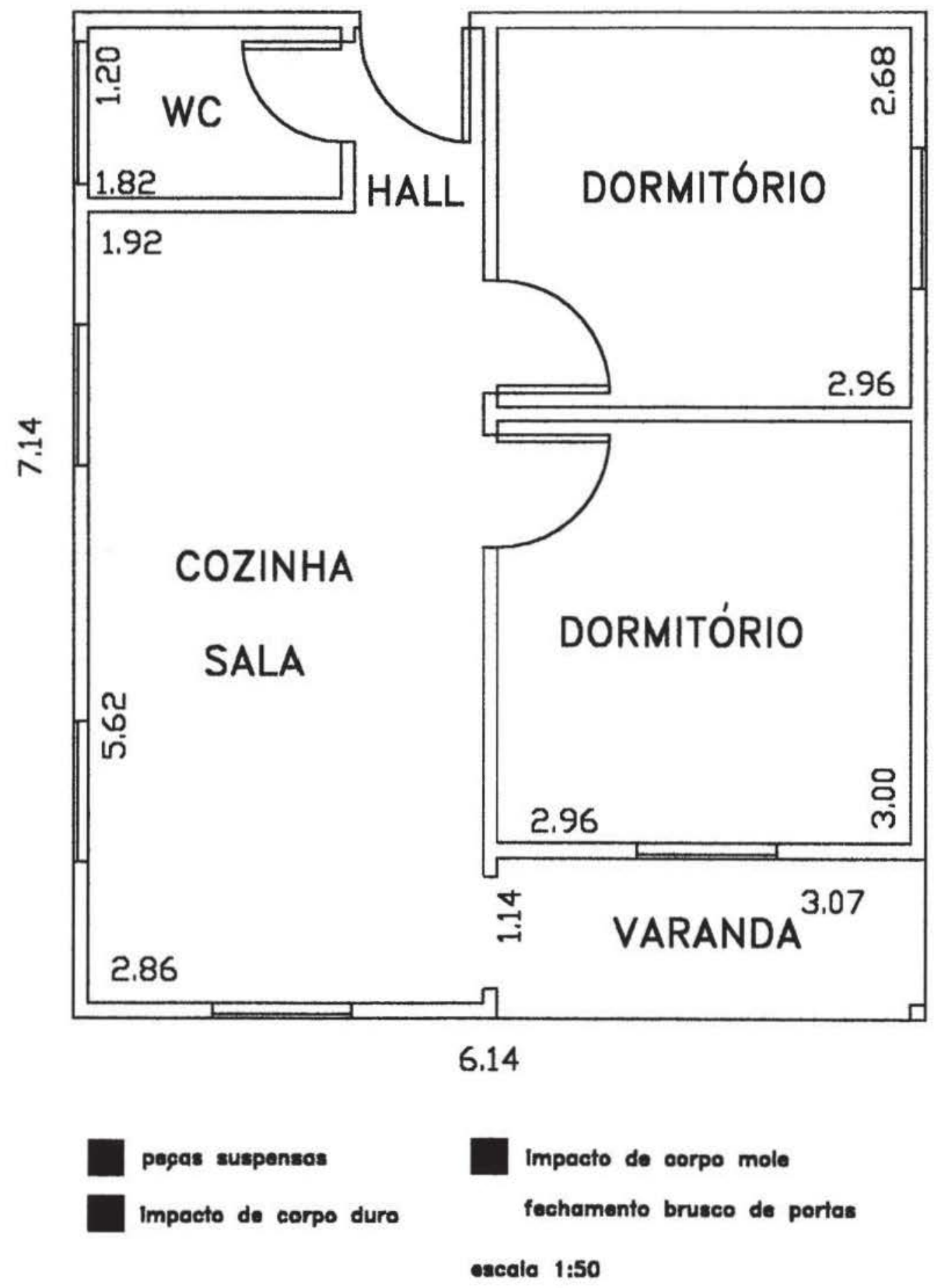


F) Sistema construtivo $F$

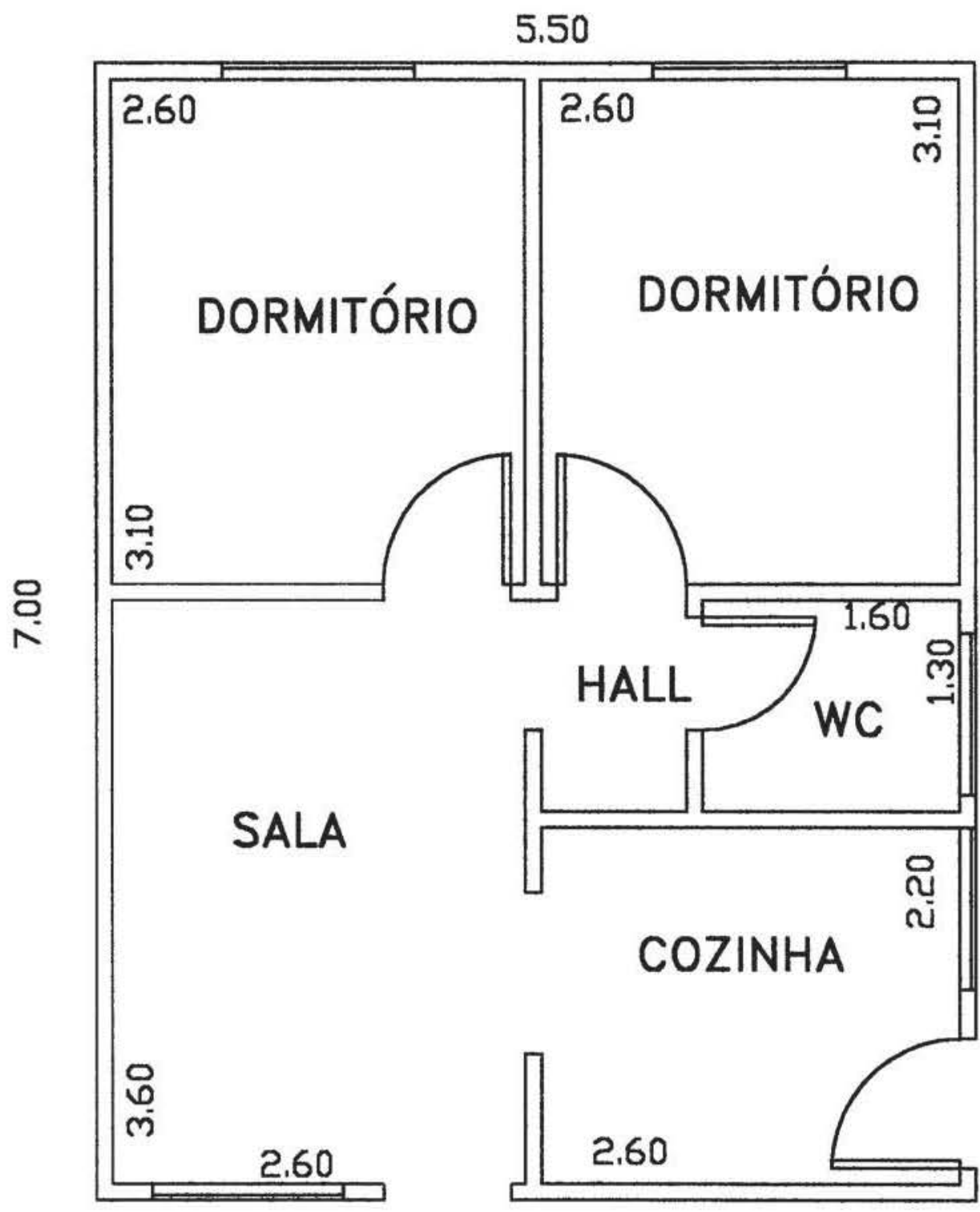

peças suspensas impacto de corpo duro

Impacto de corpo mole

fechamento brusco de portas

escala 1:50 
G)Sistema construtivo G

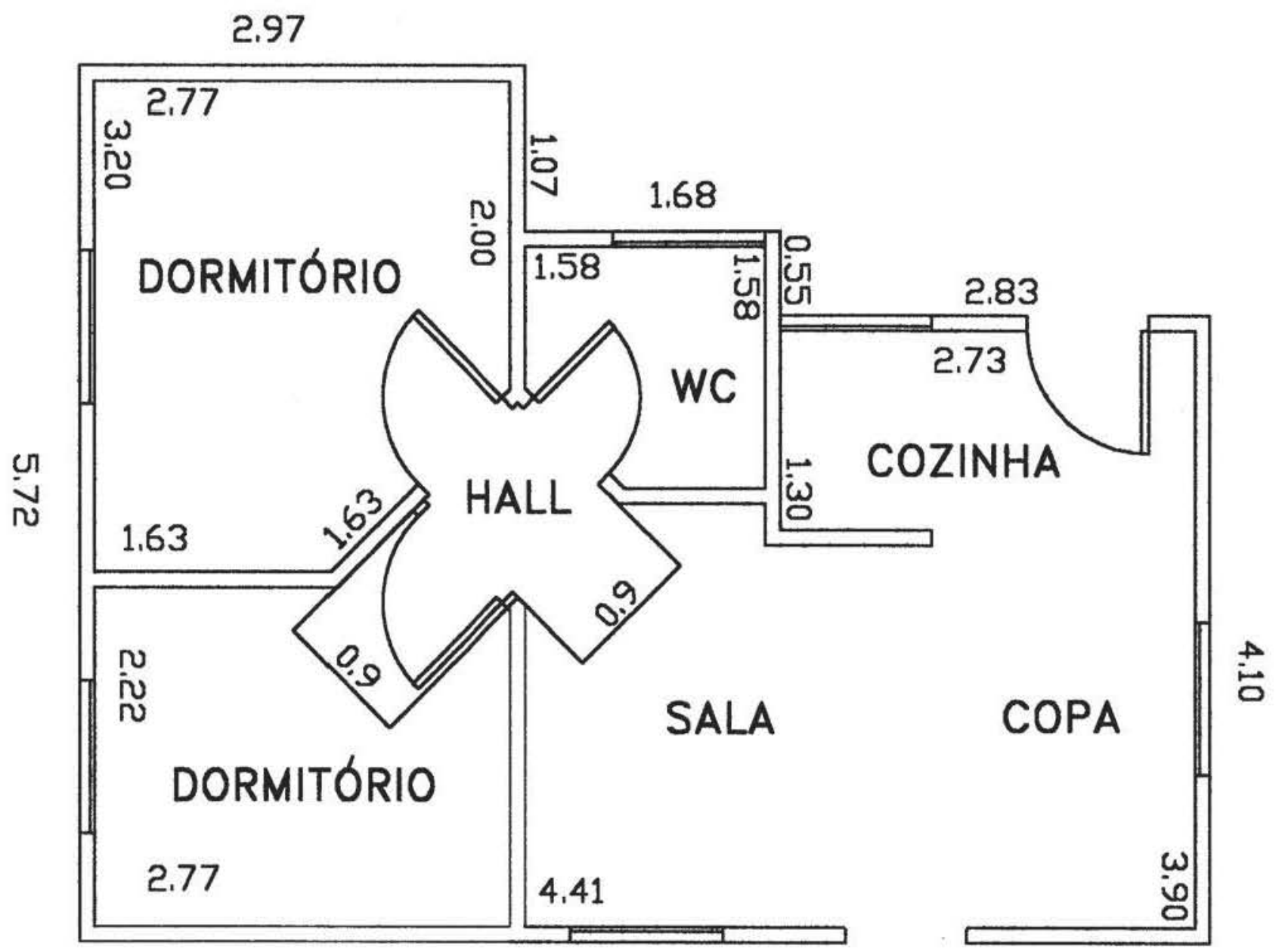

pegas suspensas

Impacto de corpo duro
Impacto de corpo mole

fechamento brusco de portas ascala 1:50 
H) Sistema construtivo $\mathbf{H}$

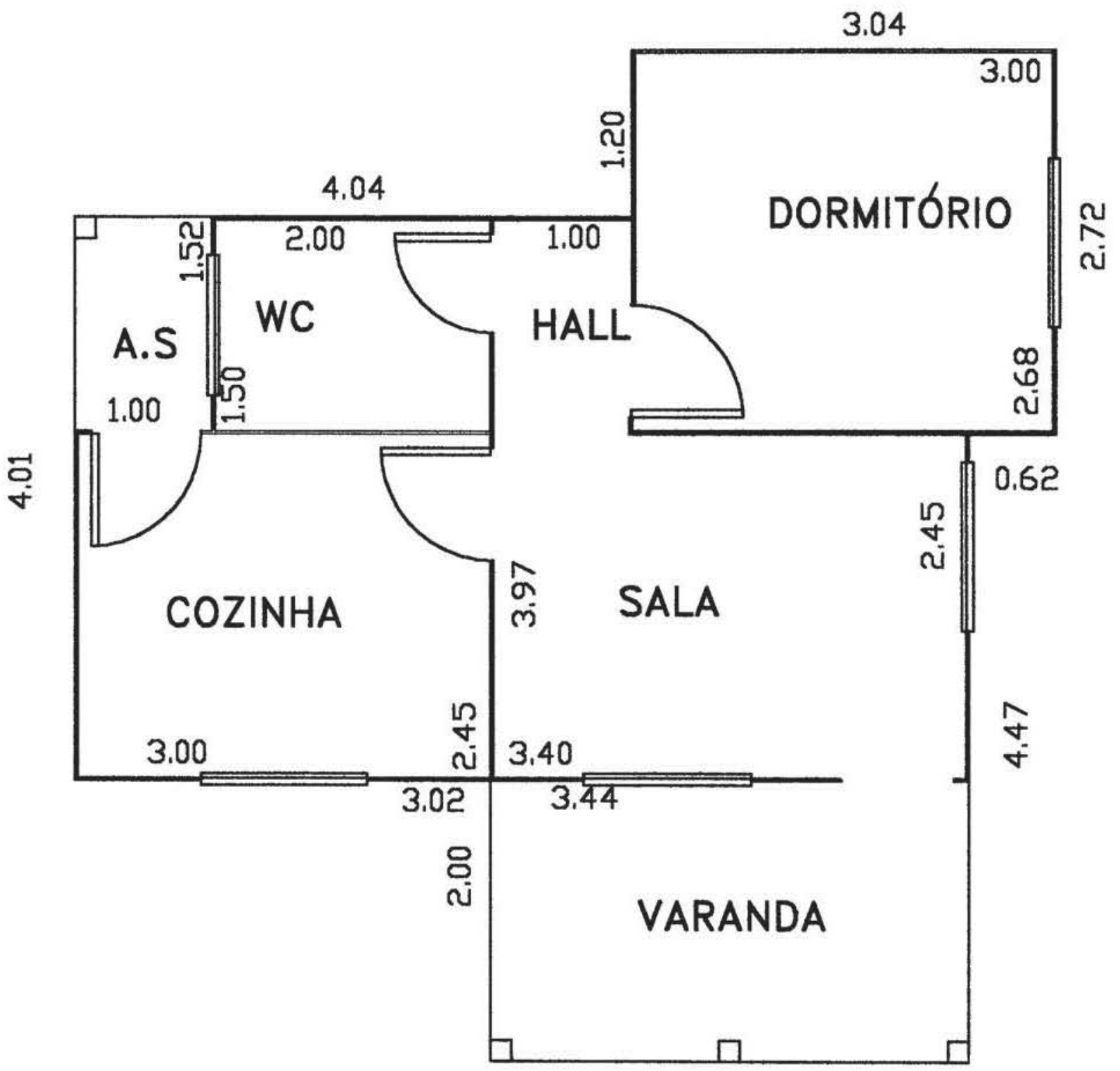

pecas suspensas Impacto de corpo duro
Impacto de corpo mole

fechamento bruseo de portas

escala 1:50 
I) Sistema construtivo I

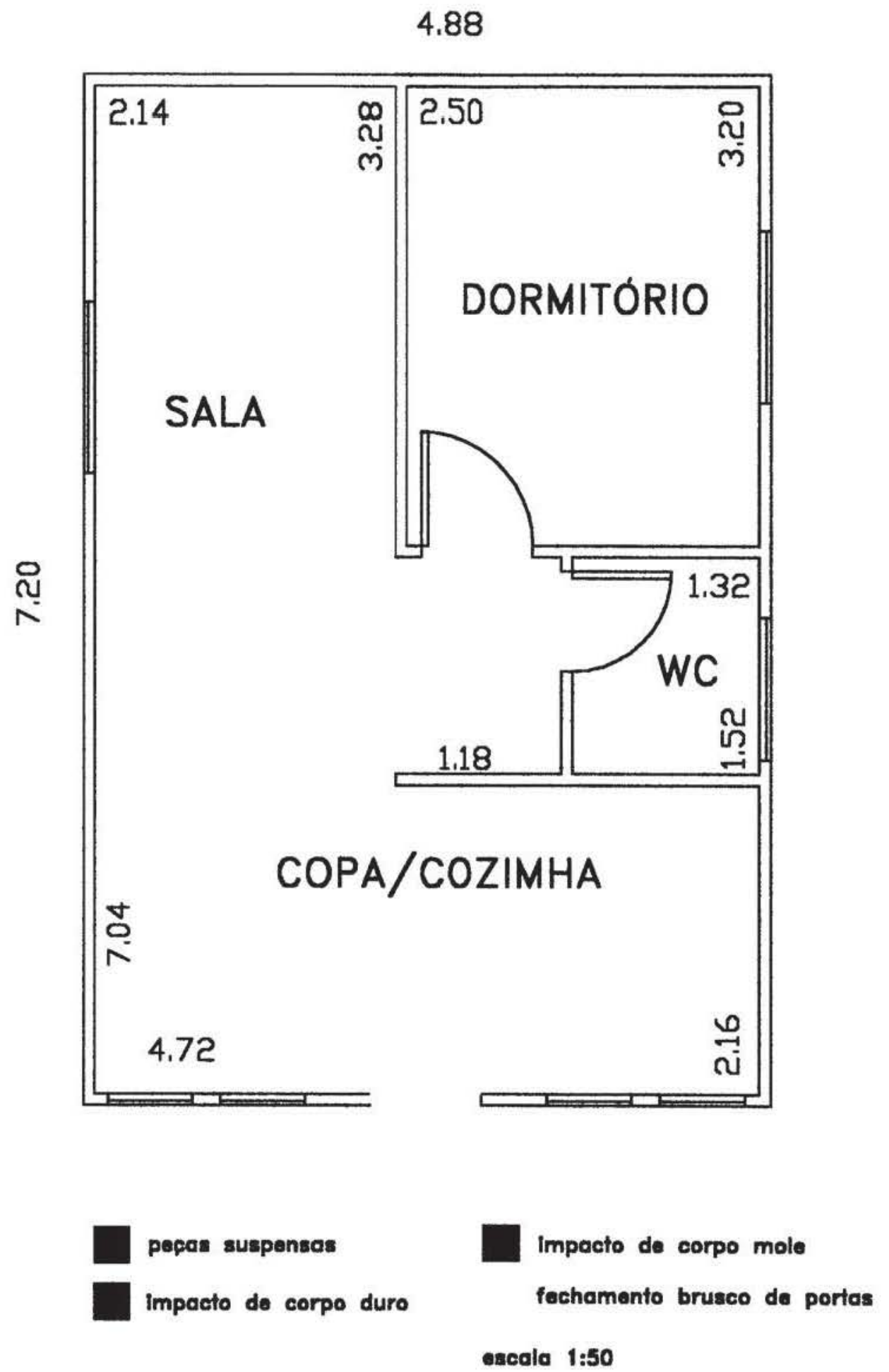


J) Sistema construtivo J

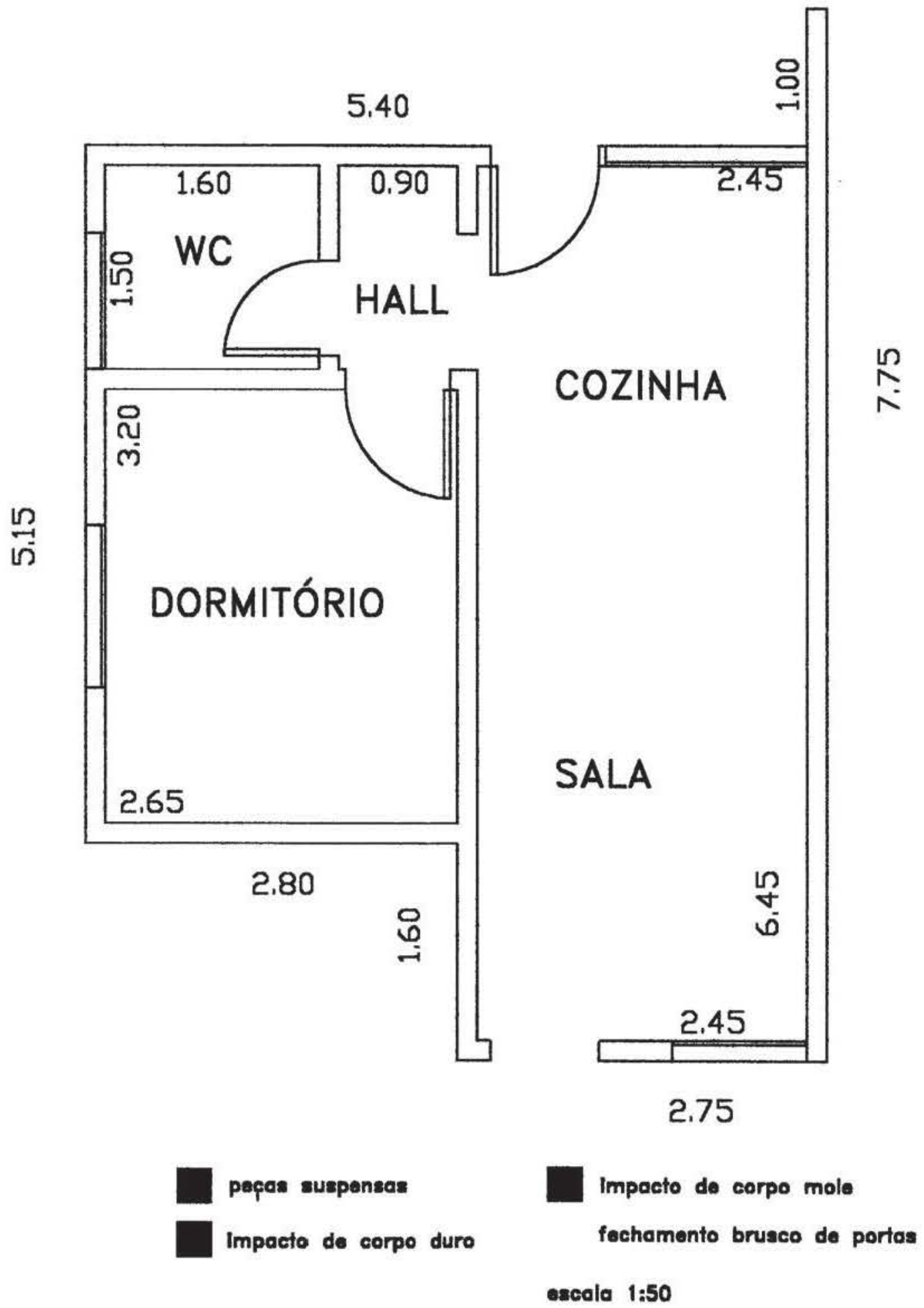


K) Sistema construtivo K

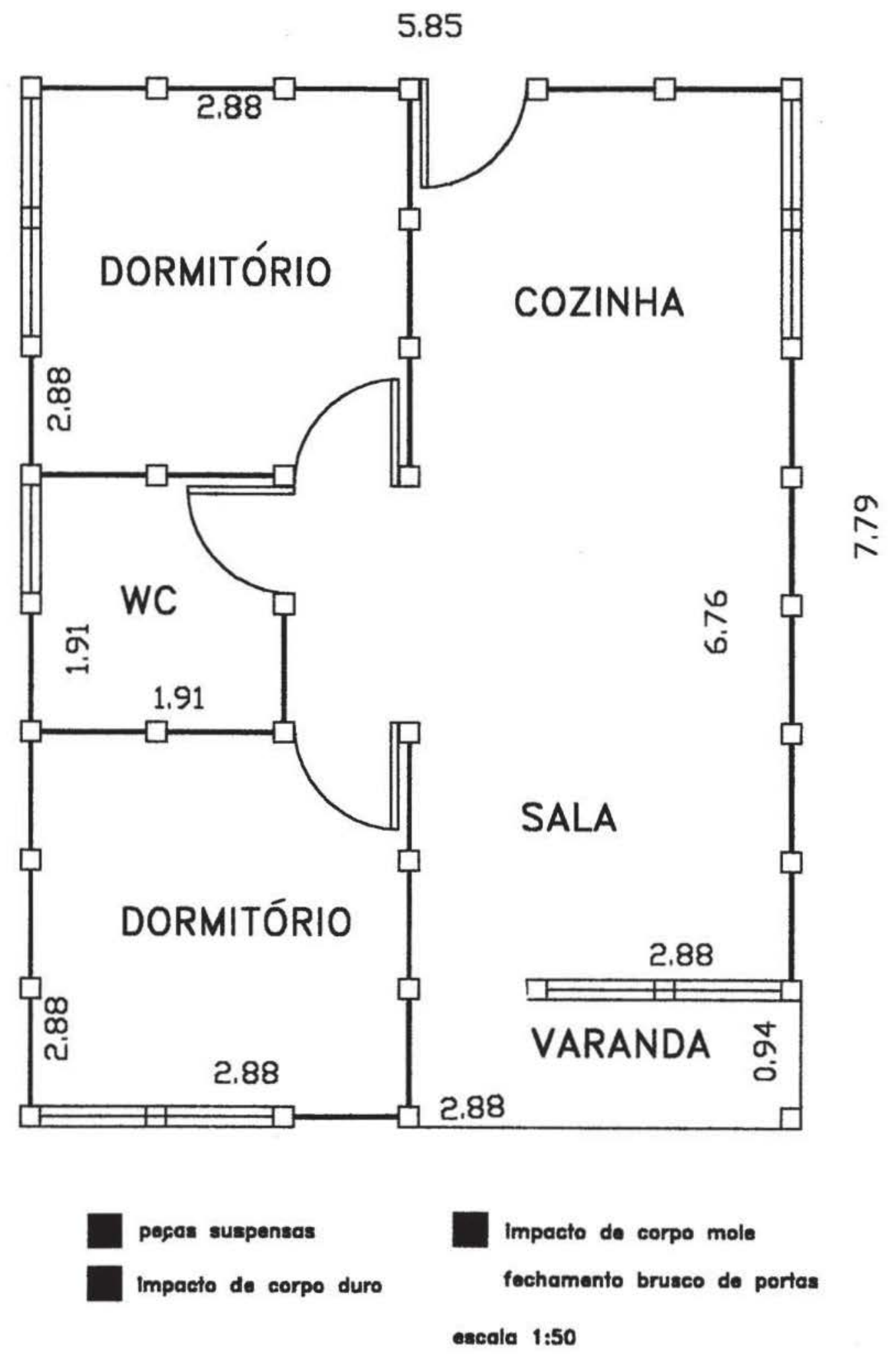




\section{BIBLIOGRAFIA}

ALMEIDA, R. (1984). A importância da avaliação do desempenho e o controle da qualidade. Construção São Paulo, Suplemento PINI, Sistemas Construtivos, p.6-7, dezembro.

ALMEIDA, R. (1984). Repensar a habitação no Brasil, uma decisão inadiável. Construção São Paulo, Suplemento PINI, Sistemas Construtivos, p.4-5, dezembro.

AMERICAN SOCIETY FOR TESTING AND MATERIALS (1985). E-695 Measuring relative resistance of wall, floor and roof construction to impact loading.

ASSOCIAÇÃO BRASILEIRA DE NORMAS TÉCNICAS (1990). MB-3256 Divisórias leves internas moduladas: verificação da resistência a impactos.

ASSOCIAÇÃO BRASILEIRA DE NORMAS TÉCNICAS (1990). MB-3259 Divisórias leves internas moduladas: verificação do comportamento sob ação de cargas provenientes de peças suspensas.

ASSOCIAÇÃO BRASILEIRA DE NORMAS TÉCNICAS (1983). NBR-8054 Porta de madeira de edificação - verificação do comportamento da folha submetida a manobras anormais.

ASSOCIAÇÃO BRASILEIRA DE NORMAS TÉCNICAS (1984). NBR-8681. Ações e segurança nas estruturas: procedimento.

ATKINSON, G. (1989). Quality marks: content and uses. In: INTERNATIONAL CONGRESS - CIB, 11., Paris. theme III, v.1, p.151-160.

BLACH, K. (1965). Rules for modular design practice. In: CIB CONGRESS, 3., Copenhague. p. 206-207,

BRASIL. Ministério do Interior (1989). Dez alternativas tecnológicas para habitação. Brasília, MINTER/PNUD.

CAVANI, G.R. (1993). Avaliação de desempenho de sistema construtivo integrado por painéis sanduíches com miolo em poliestireno expandido e faces em argamassa armada. In: SIMPÓSIO DE ENGENHARIA CIVIL DE ILHA SOLTEIRA, 4., Ilha Solteira, 6-8 outubro. Anais. p.15-24

CENTRE SCIENTIFIQUE ET TECHINIQUE DE LA CONSTRUCTION (1980). Guide des performances du bâtiment. Bruxelas. 9v. 
DUARTE, R.B. (1981). Avaliação de sistemas construtivos industrializados. In: SIMPÓSIO LATINO AMERICANO SOBRE RACIONALIZAÇÃO DA CONSTRUÇÃO E SUA APLICAÇÃO ÀS HABITAÇŌES DE INTERESSE SOCIAL, São Paulo. v.1, p.735-749

ESCOLA POLITÉCNICA DA UNIVERSIDADE DE SÃO PAULO (1988). Normalização, controle da qualidade e desempenho. São Paulo, Departamento de Engenharia de Construção Civil. (Notas de Aula).

FOSTER, B. (1970). European systems for evaluation and approval of innovations in buildings. Washington, National Bureau of Standards.

GIBSON, E.J. (1977). The performance concept in building. In: RECHERCHE INTERNATIONALE DU BÂTIMENT. Edimbourg, CIB.

GJELSVIK, T. (1989). Quality assurance and quality certification of building materials and components. In: INTERNATIONAL CONGRESS - CIB, 11., Paris. theme III, v.2, p.371-378

INSTITUTO DE PESQUISAS TECNOLÓGICAS DO ESTADO DE SÃO PAULO (1981). Avaliação de desempenho de habitações térreas unifamiliares: segurança estrutural. São Paulo, IPT. Documento Preliminar, anexo do relatório 16277. 107p.

INSTITUTO DE PESQUISAS TECNOLÓGICAS DO ESTADO DE SÃO PAULO. Divisão de edificações (1988). Tecnologia de edificações. São Paulo, PINI.

LEA, F.M. (1962). Preface. In: CIB CONGRESS, 2., Cambridge. Inovation in building.

LEGGET, R. F. (1965). Building codes, test methods, and industrialised building. In: CIB CONGRESS, 3., Copenhague. p.193-194

MACHADO JÚNIOR, E.F. (1991). Casas populares pré-moldadas em argamassa armada: procura de uma solução econômica e confortável. São Paulo. Tese (Doutorado) - Escola de Engenharia de São Carlos, Universidade de São Paulo.

MARTUCCI, R. (1990). Projeto para edificações habitacionais. utopia ou desafio? São Paulo. Tese (Doutorado) - Faculdade de Arquitetura e Urbanismo, Universidade de São Paulo.

MATHEY, R.G; REICHARD, T.W. (1968). Performance testing of exterior walls. Washington, National Bureau of Standards. 
MITIDIERE FILHO, C.V.; SOUSA, R. (1994). Avaliação de desempenho de sistemas construtivos destinados à habitação popular: aplicação prática $1^{\text {a }}$ Parte. São Paulo, IPT.

MITIDIERE FILHO, C.V.; SOUSA, R. (1994). Avaliação de desempenho de sistemas construtivos destinados à habitação popular: aplicação prática $2^{a}$ Parte. São Paulo, IPT.

MITIDIERE FILHO, C.V.; SOUSA, R. (1994). Avaliação de desempenho de sistemas construtivos destinados à habitação popular: conceituação e metodologia. São Paulo, IPT.

MITIDIERE FILHO, C.V; GUELPA, D.F.V. (1992). Avaliação de desempenho de sistemas construtivos inovadores destinados a habitações térreas unifamiliares: desempenho estrutural. Boletim Técnico da Escola Politécnica da USP, Departamento de Construção Civil, BT/PCC/61.

MITIDIERI FILHO, C.V. (1988). Avaliação de desempenho de sistemas construtivos inovadores destinados a habitações térreas unifamiliares: desempenho estrutural. São Paulo. Dissertação (Mestrado) - Escola Politécnica, Universidade de São Paulo.

NEVES, C.M.M. (1993). Desempenho de paredes de edificaçōes em uso: metodologia de avaliação. In: SIMPÓSIO IBERO-AMERICANO SOBRE TÉCNICAS CONSTRUTIVAS INDUSTRIALIZADAS PARA HABITAÇÃO DE INTERESSE SOCIAL, 3., São Paulo. v.2, p.50-59

OLIVEIRA, F.L.; FRIAS, F.A.O.; MACHADO JÚNIOR, E.F. (1996). Desempenho estrutural de sistemas inovadores: estudo de caso. In: CONGRESSO TÉCNICO-CIENTÍFICO DE ENGENHARIA CIVIL, Florianópolis. Anais. v.5, p.795-806

OLIVEIRA, F.L. et al. (1995). Análise do desempenho estrutural de sistemas construtivos Inovadores através de ensaios no campo para avaliação da segurança estrutural: estudo de caso vila tecnológica de Ribeirão Preto,SP. In: SIMPÓSIO DE INICIAÇÃO CIENTÍFICA DA UNIVERSIDADE DE SÃO PAULO, 3., São Carlos. Exatas e engenharia. v. 2, p. 75

OLIVEIRA, R.R. (1993). Análise do processo produtivo de edificações: estudo em três tecnologias construtivas. In: SIMPÓSIO IBEROAMERICANO SOBRE TÉCNICAS CONSTRUTIVAS INDUSTRIALIZADAS PARA HABITAÇÃO DE INTERESSE SOCIAL, 3., São Paulo. v.2, p.110115 
PASTOR, J.A.; NAVAS, A. (1993). Producción y control de calidad de vivienda de bajo costo en Costa Rica. In: SIMPÓSIO IBEROAMERICANO SOBRE TÉCNICAS CONSTRUTIVAS INDUSTRIALIZADAS PARA HABITAÇÃO DE INTERESSE SOCIAL, 3.,São Paulo. v.3, p.621631

REIS, P.F.; BASTOS, P.K.X. (1994). Construções habitacionais em Juiz de Fora: diagnóstico técnico. In: CONGRESSO DE ENGENHARIA CIVIL DA UNIVERSIDADE FEDERAL DE JUIZ DE FORA, 1., Juiz de Fora. v.2, p.136-147

REVERDITO, F.G. (1993). Criterios para una evaluación integral de sistemas construtivos aplicables a la vivienda de interés social. In: SIMPÓSIO IBERO-AMERICANO SOBRE TÉCNICAS CONSTRUTIVAS INDUSTRIALIZADAS PARA HABITAÇÃO DE INTERESSE SOCIAL, 3., São Paulo. v.2, p.116-127

ROSSO, T. Normalização e desempenho dos materiais de construção. Cadernos do Centro Brasileiro da Construção n. 6/2, São Paulo, s.d.

ROSSO, T. Organização de um sistema de controle de qualidade da construção baseado em certificados de homologação (Agrément). Cadernos do Centro Brasileiro da Construção n. 4/5, São Paulo, s.d.

SÃO PAULO. Prefeitura Municipal (1992). Código de obras e edificações do município de São Paulo, Lei $n^{\circ} 11.228$ de 25 de junho de1992. São Paulo, Atlas.

SNECK, T. (1965). Material engineering as a tool industrialisation process. In: CIB CONGRESS, 3., Copenhague. p.360-361

SOUZA, R. (1981). A avaliação de desempenho aplicada a novos componentes e sistemas construtivos para habitação. In: SIMPÓSIO LATINO AMERICANO SOBRE RACIONALIZAÇÃO DA CONSTRUÇÃO E SUA APLICAÇÃO ÀS HABITAÇÕES DE INTERESSE SOCIAL, São Paulo. v.1, p.247-256

SOUZA, R. (1984). Avaliação de desempenho aplicada a novos componentes e sistemas construtivos para habitação. São Paulo, IPT.

SOUZA, R. (1988). Normalização e controle de qualidade na construção civil. In: SIMPÓSIO DE DESEMPENHO DE MATERIAIS E COMPONENTES DE CONSTRUÇÃO CIVIL, 1., Florianópolis. p.13-25

SOUZA, R. (1983). A contribuição do conceito de desempenho para a avaliação do edifício e suas partes: aplicação às janelas de uso habitacional. São Paulo. Dissertação (Mestrado) - Escola Politécnica, Universidade de São Paulo. 
SOUZA. R. (1989). Qualidade, modernização e desenvolvimento: diretrizes para atualização tecnológica da indústria da construção civil. In: SIMPÓSIO DE DESEMPENHO DE MATERIAIS E COMPONENTES DE CONSTRUÇÃO CIVIL, 2., Florianópolis. p.131-149.

THOMAZ, E. (1993). Sistemas construtivos para habitações de interesse social: proposta de avaliação e classificação pela relação custo/benefício. In: SIMPÓSIO IBERO-AMERICANO SOBRE TÉCNICAS CONSTRUTIVAS INDUSTRIALIZADAS PARA HABITAÇÃO DE INTERESSE SOCIAL, 3., São Paulo. v.3, p.591-598

UNION EUROPÉENNE POUR L'AGREMENT TECHNIQUE DANS LA CONSTRUCTION (1994). Les documents interprétatifs de la directive européene sur les produits de construction. Cahiers du Centre Scientifique et Techinique du Bâtiment, n.2705.

UNION EUROPÉENNE POUR L'AGREMENT TECHNIQUE DANS LA CONSTRUCTION (1973). Directives communes pour l'agrément des cloisons légéres. Cahiers du Centre Scientifique et Techinique du Bâtiment, n.1215, p.2-9.

UNION EUROPÉENNE POUR L'AGREMENT TECHNIQUE DANS LA CONSTRUCTION (1965). Directives communes pour l'agrément des maisons légéres. Cahiers $d u$ Centre Scientifique et Techinique du Bâtiment, n.660. p.1-17.

VASAS, S. (1989). Relation between quality and innovation in the construction process. In: INTERNATIONAL CONGRESS - CIB, 11., Paris. theme III, v.2, p.181-188 